\title{
Field Test of Advanced Duct-Sealing Technologies within the Weatherization Assistance Program
}

November 2001

Mark P. Ternes

Ho-Ling Hwang 


\section{DOCUMENT AVAILABILITY}

Reports produced after January 1, 1996, are generally available free via the U.S. Department of Energy (DOE) Information Bridge:

Web site: http://www.osti.gov/bridge

Reports produced before January 1,1996, may be purchased by members of the public from the following source:

National Technical Information Service

5285 Port Royal Road

Springfield, VA 22161

Telephone: 703-605-6000 (1-800-553-6847)

TDD: 703-487-4639

Fax: 703-605-6900

E-mail: info@ntis.fedworld.gov

Web site: http://www.ntis.gov/support/ordernowabout.htm

Reports are available to DOE employees, DOE contractors, Energy Technology Data Exchange (ETDE) representatives, and International Nuclear Information System (INIS) representatives from the following source:

Office of Scientific and Technical Information

P.O. Box 62

Oak Ridge, TN 37831

Telephone: 865-576-8401

Fax: 865-576-5728

E-mail: reports@adonis.osti.gov

Web site: http://www.osti.gov/contact.html

This report was prepared as an account of work sponsored by an agency of the United States government. Neither the United States government nor any agency thereof, nor any of their employees, makes any warranty, express or implied, or assumes any legal liability or responsibility for the accuracy, completeness, or usefulness of any information, apparatus, product, or process disclosed, or represents that its use would not infringe privately owned rights. Reference herein to any specific commercial product, process, or service by trade name, trademark, manufacturer, or otherwise, does not necessarily constitute or imply its endorsement, recommendation, or favoring by the United States government or any agency thereof. The views and opinions of authors expressed herein do not necessarily state or reflect those of the United States government or any agency thereof. 
Field Test of Advanced Duct-Sealing Technologies within the Weatherization Assistance Program

\author{
Mark P. Ternes
}

Ho-Ling Hwang

November 2001

Prepared by the OAK RIDGE NATIONAL LABORATORY

Oak Ridge, Tennessee 37831

managed by

UT-BATTELLE

for the

U.S. DEPARTMENT OF ENERGY

under contract number DE-AC05-00OR22725 



\section{CONTENTS}

LIST OF FIGURES $\ldots \ldots \ldots \ldots \ldots \ldots \ldots \ldots \ldots \ldots \ldots \ldots \ldots \ldots \ldots \ldots \ldots \ldots$

LIST OF TABLES $\ldots \ldots \ldots \ldots \ldots \ldots \ldots \ldots \ldots \ldots \ldots \ldots \ldots \ldots \ldots \ldots \ldots$ vii

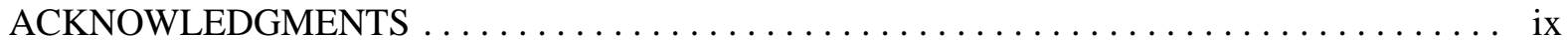

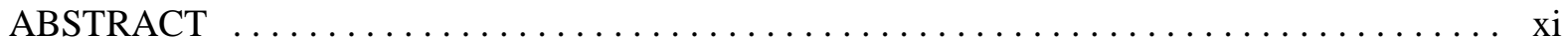

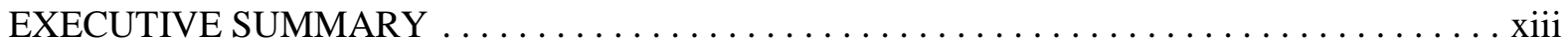

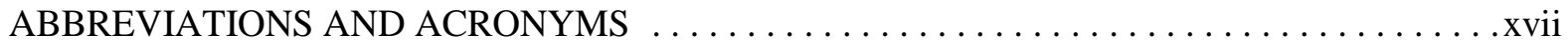

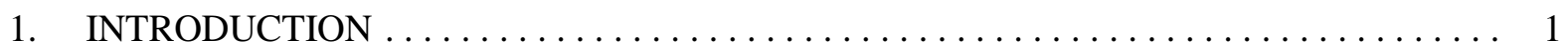

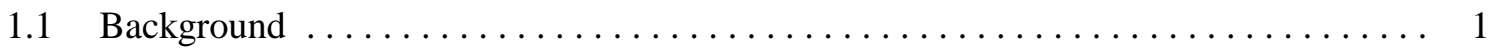

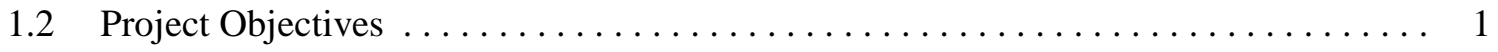

2. DUCT-SEALING TECHNOLOGIES USED IN THE FIELD TESTS $\ldots \ldots \ldots \ldots \ldots \ldots$

2.1 Conventional, Best-Practice Duct-Sealing Technology $\ldots \ldots \ldots \ldots \ldots \ldots \ldots \ldots \ldots$

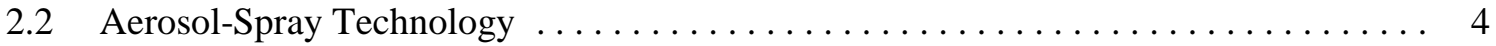

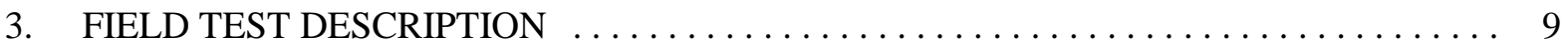

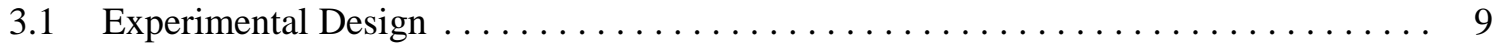

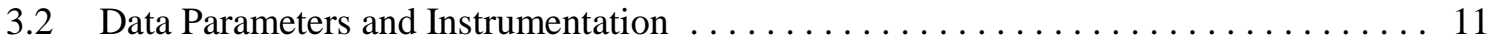

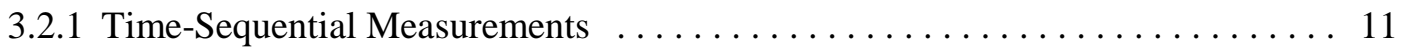

3.2.2 Point-in-Time Measurements . . . . . . . . . . . . . . . . . . . . 12

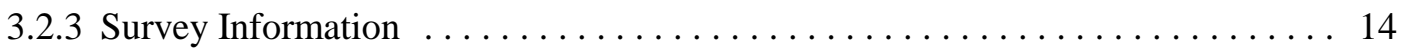

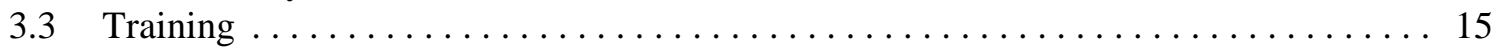

4. CHARACTERISTICS OF THE HOUSES IN THE STUDY $\ldots \ldots \ldots \ldots \ldots \ldots \ldots \ldots \ldots 17$

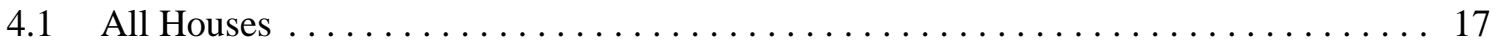

4.2 Comparison between Best-Practice and Aerosol Houses $\ldots \ldots \ldots \ldots \ldots \ldots \ldots \ldots$

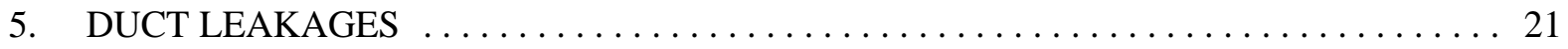

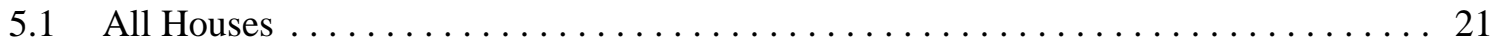

5.2 Comparison between Best-Practice and Aerosol Houses . . . . . . . . . . . . . . . 25

5.3 Comparison between Agencies $\ldots \ldots \ldots \ldots \ldots \ldots \ldots \ldots \ldots \ldots \ldots \ldots \ldots \ldots \ldots \ldots \ldots \ldots$

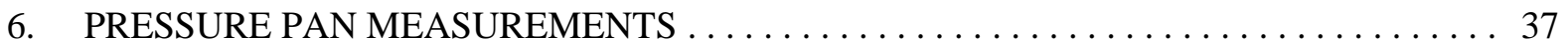

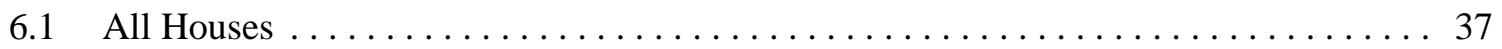

6.2 Comparison between Best-Practice and Aerosol Houses . . . . . . . . . . . . . 38

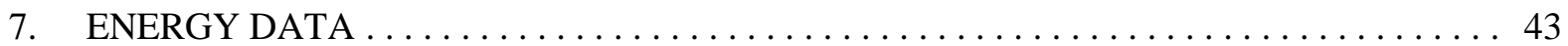

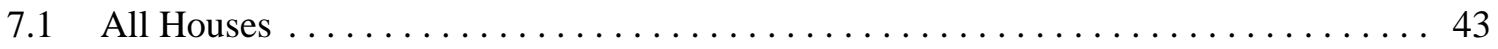

7.2 Comparison between Best-Practice and Aerosol Houses $\ldots \ldots \ldots \ldots \ldots \ldots \ldots . \ldots 4$

7.3 Comparison among Weatherization Agencies $\ldots \ldots \ldots \ldots \ldots \ldots \ldots \ldots \ldots$

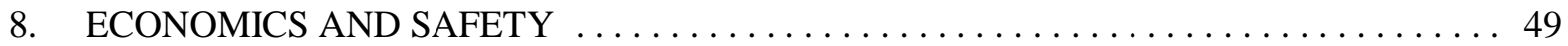

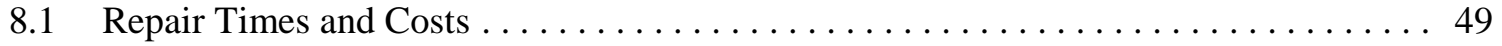

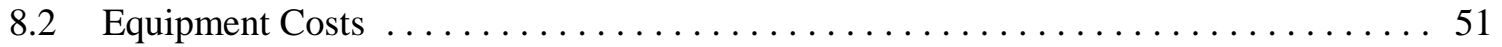




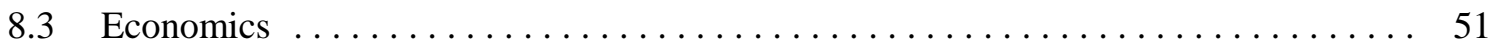

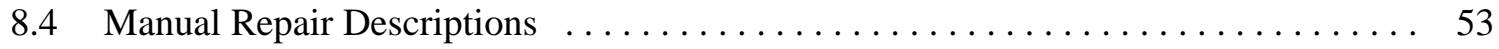

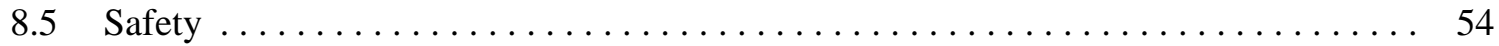

9. WEATHERIZATION AGENCY INPUT $\ldots \ldots \ldots \ldots \ldots \ldots \ldots \ldots \ldots \ldots \ldots \ldots \ldots$

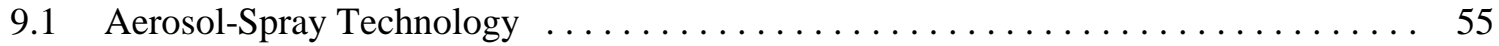

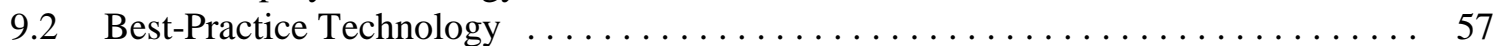

10. CONCLUSIONS AND RECOMMENDATIONS $\ldots \ldots \ldots \ldots \ldots \ldots \ldots \ldots \ldots \ldots$

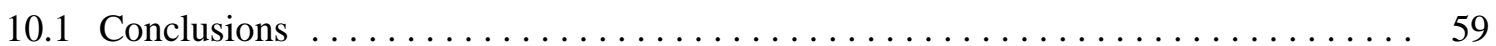

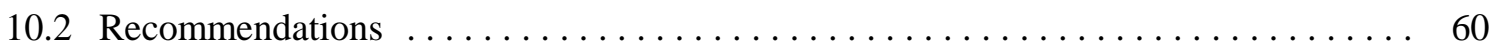

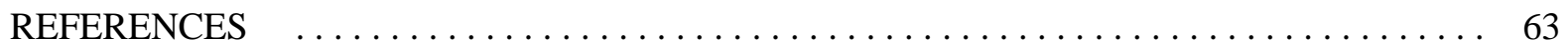

APPENDIX A. FIELD DATA COLLECTION FORMS AND PROCEDURES $\ldots \ldots \ldots \ldots$

APPENDIX B. WEATHERIZATION AGENCY QUESTIONNAIRE $\ldots \ldots \ldots \ldots \ldots \ldots \ldots .97$ 


\section{FIGURES}

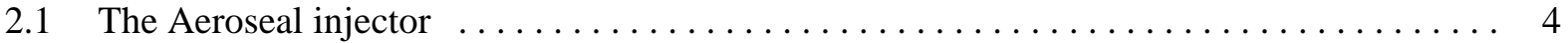

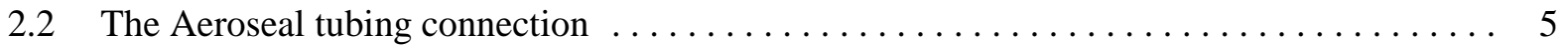

3.1 Location of the five weatherization agencies participating in the study $\ldots \ldots \ldots \ldots \ldots 10$

3.2 The difference in energy use calculated by the ASAP and alternative analysis methods for a sample of houses as a function of the difference in reference

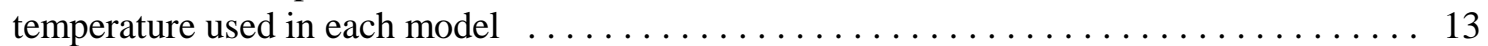

4.1 Location of ducts in the field test houses $\ldots \ldots \ldots \ldots \ldots \ldots \ldots \ldots \ldots \ldots \ldots \ldots$

4.2 Types of return and supply ducts found in the field test houses $\ldots \ldots \ldots \ldots \ldots \ldots \ldots$

5.1 Comparison of duct leakages measured by pressurizing the supply ducts to $25 \mathrm{~Pa}$ with those measured by pressurizing the return ducts to $25 \mathrm{~Pa} \ldots \ldots \ldots \ldots \ldots 22$

5.2 Comparison of total duct leakages to duct leakages to the outside $\ldots \ldots \ldots \ldots \ldots \ldots 23$

5.3 Distribution of total duct leakage based on pressurizing the supply ducts to $25 \mathrm{~Pa} \ldots \ldots 24$

5.4 Distribution of total duct-leakage reductions based on pressurizing the

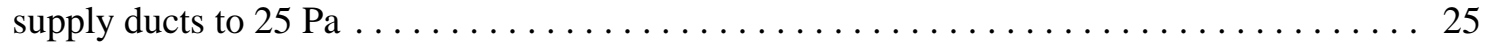

5.5 Distribution of the percentage reductions in total duct leakage based on

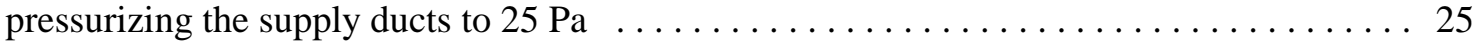

5.6 Comparison of duct leakage reductions to pre-retrofit duct leakages using

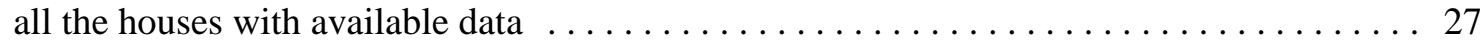

5.7 Comparison of duct-leakage reductions to pre-retrofit duct leakages using a subset of aerosol-spray-treated and best-practice-treated houses with

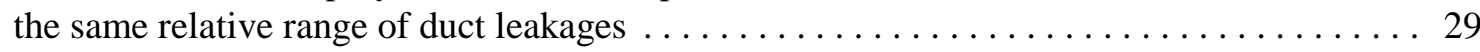

5.8 Average pre- and post-retrofit duct leakages for each of the five weatherization

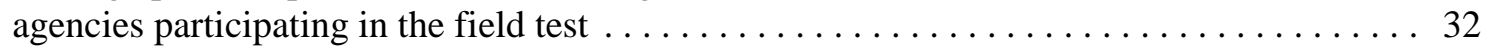

5.9 Average percentage reductions in duct leakage for each of the five weatherization agencies participating in the field test $\ldots \ldots \ldots \ldots \ldots \ldots \ldots \ldots \ldots \ldots \ldots$

5.10 Comparison of total duct leakage reductions (based on supply pressure) achieved by each weatherization agency, as a function of pre-retrofit total duct leakage using the aerosol-spray and best-practice technologies $\ldots \ldots \ldots \ldots 33$

5.11 Comparison of total duct leakage reductions (based on supply pressure) achieved by each weatherization agency using the aerosol-spray and

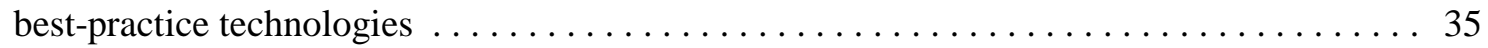

6.1 Pre- and post-retrofit distributions of total house pressure pan readings $\ldots \ldots \ldots \ldots \ldots 37$

6.2 Pre- and post-retrofit distributions of average house pressure pan readings $\ldots \ldots \ldots \ldots 38$

6.3 Pre- and post-retrofit distributions of the number of registers in a house

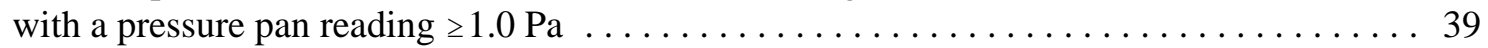

6.4 Pre- and post-retrofit distributions of total pressure pan readings for the aerosol-spray-treated and best-practice-treated houses $\ldots \ldots \ldots \ldots \ldots \ldots \ldots \ldots \ldots . \ldots \ldots$

7.1 Energy savings as a function of duct leakage reduction $\ldots \ldots \ldots \ldots \ldots \ldots \ldots \ldots 4$

7.2 Energy savings as a function of pre-retrofit total duct leakage based on supply pressure $\ldots 45$

7.3 Annual savings for houses with ducts located completely inside the conditioned space of the house and for those with some ducts located outside the

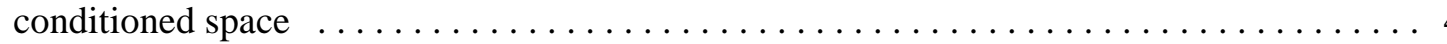





\section{TABLES}

3.1 Comparison of results from ASAP analysis and an alternative analysis method $\ldots \ldots \ldots 13$

5.1 Average duct leakage results for all field test houses $\ldots \ldots \ldots \ldots \ldots \ldots \ldots \ldots \ldots 21$

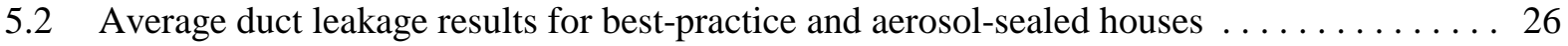

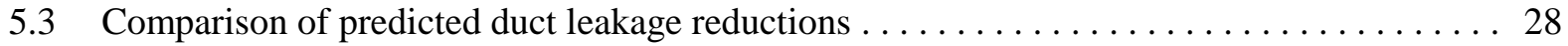

5.4 Intercepts of regression models along the horizontal axis $(\mathrm{cfm} 25) \ldots \ldots \ldots \ldots \ldots \ldots$

5.5 Comparison of predicted duct-leakage reductions for the subset of comparable houses . . . 30

5.6 Intercepts of regression models along the horizontal axis ( $\mathrm{cfm} 25)$ for the subset

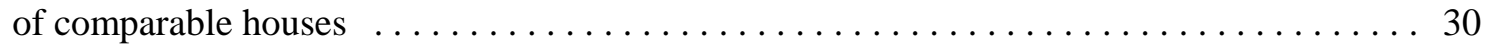

5.7 Average duct leakage results for simulated set of best-practice and

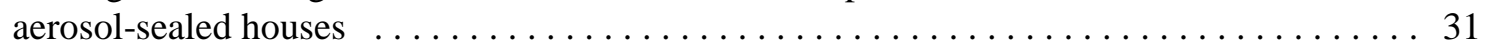

5.8 Coefficient of determination $\left(\mathrm{R}^{2}\right)$ values for the models shown in Fig. $5.10 \ldots \ldots \ldots \ldots . .34$

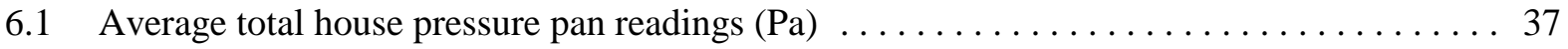

6.2 Percentage of registers with pressure pan readings $\geq 1.0 \mathrm{~Pa} \ldots \ldots \ldots \ldots \ldots \ldots \ldots$

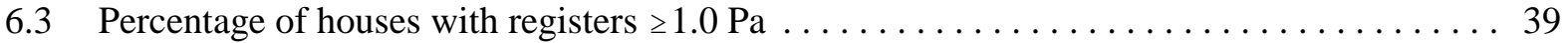

7.1 Estimates of house energy use (therms): mean values $\ldots \ldots \ldots \ldots \ldots \ldots \ldots \ldots \ldots$

7.2 Estimates of hour energy use (therms): median values $\ldots \ldots \ldots \ldots \ldots \ldots \ldots \ldots \ldots$

7.3 Estimates of house energy use (therms) by weatherization agency: mean values $\ldots \ldots \ldots 47$

7.4 Estimates of house energy use (therms) by weatherization agency: median values . . . . 47

8.1 Average repair times and costs for the best-practice and aerosol-spray approaches . . . . . 49

8.2 Average repair times (minutes) for each weatherization agency $\ldots \ldots \ldots \ldots \ldots \ldots \ldots$

8.3 Average economics for the best-practice and aerosol approaches $\ldots \ldots \ldots \ldots \ldots \ldots 2$ 



\section{ACKNOWLEDGMENTS}

The authors wish to acknowledge the U.S. Departments of Housing and Urban Development (HUD) and Energy (DOE). HUD provided funds to DOE through an Interagency Agreement in support of this project as part of its Partnership for Advancing Technology in Housing (PATH) Program. DOE's Office of Building Technology, State and Community Programs provided sufficient funding through its Weatherization Assistance Program to complete the project. DOE's Oak Ridge Field Office and its Weatherization Program staff also provided invaluable assistance in identifying and working with the local weatherization agencies.

The authors are especially grateful to the weatherization agencies who participated in this field test. Without their involvement, the field test would not have been possible. In addition to taking on the additional production load of finding 16 houses for the field test and then sealing their ducts during the middle of the winter, the agencies had to attend several training sessions around the Thanksgiving and Christmas holidays which further affected their schedules. The agencies and their executive directors and participating crew members were as follows:

Community Action of South Eastern West Virginia

Bluefield, WV

Emory White

Virginia Mountain Housing, Inc.

Christiansburg, VA

Bill Beachy, Executive Director

Anthony Cox

Iowa East Central TRAIN (Teaching, Rehabilitating, Aiding Iowa's Needy)

Davenport, IA

Mike Loos, Executive Director

Tony Reed

Dave Sexton
Wyoming Energy Council, Inc.

Laramie, WY

Robert Doherty, Executive Director

Emiliano Lopez

Chris Baker

The Opportunity Council

Bellingham, WA

Dave Finet, Executive Director

Chris Clay

John Davies

We were also assisted by two contractors who devoted a lot of their energy to the study. Karen Linner, Center for Energy and Environment, implemented the energy monitoring part of the project. She trained weatherization agencies on instrumentation installation and data collection, maintained the energy database, and performed the initial energy savings analyses on each house. Mark Modera, Aeroseal, Inc., reviewed field test goals and procedures, trained crews on use of the aerosol-spray technology, and answered innumerable questions from the crews during the sealing work.

The authors would like to thank Bob Wendt of Oak Ridge National Laboratory (ORNL) for helping to identify, contact, and select the weatherization agencies to participate in the field test at the start of the study. We are also especially grateful to Ian Sacs, an ORNL summer student and current University of Tennessee graduate student, who created the database for the non-energy data collected during the study.

We are especially indebted to Joel Eisenberg, ORNL, for developing this project with our DOE sponsors and for supporting us when funding and time constraints made the project difficult to accomplish. 



\begin{abstract}
A field test of an aerosol-spray duct-sealing technology and a conventional, best-practice approach was performed in 80 homes to determine the efficacy and programmatic needs of the duct-sealing technologies as applied in the U.S. Department of Energy Weatherization Assistance Program. The field test was performed in five states: Iowa, Virginia, Washington, West Virginia, and Wyoming. The study found that, compared with the best-practice approach, the aerosol-spray technology is 50\% more effective at sealing duct leaks and can potentially reduce labor time and costs for duct sealing by $70 \%$, or almost 4 crew-hours. Further study to encourage and promote use of the aerosol-spray technology within the Weatherization Assistance Program is recommended. A pilot test of fullproduction weatherization programs using the aerosol-spray technology is recommended to develop approaches for integrating this technology with other energy conservation measures and minimizing impacts on weatherization agency logistics. In order to allow or improve adoption of the aerosolspray technology within the Weatherization Assistance Program, issues must be addressed concerning equipment costs, use of the technology under franchise arrangements with Aeroseal, Inc. (the holders of an exclusive license to use this technology), software used to control the equipment, safety, and training. Application testing of the aerosol-spray technology in mobile homes is also recommended.
\end{abstract}





\section{EXECUTIVE SUMMARY}

According to Lawrence Berkeley National Laboratory data, existing air distribution (duct) systems in U.S. homes are typically only 50 to $75 \%$ efficient due to a combination of air leaks and thermal losses. The current best practice for sealing leaks in duct systems is to use a combination of duct leakage measurements (total duct leakage and duct leakage to the outside), pressure pan measurements, and, less frequently, the measured change in indoor air pressure when the air handler fan is turned on to determine if duct sealing is needed and to locate duct leakage sites. Ducts are then sealed manually on the basis of these measurements as well as on the basis of visual inspections that identify obvious or potential leakage sites based on what weatherization crews have learned from past experience. Duct sealing work includes reattaching ducts that have become disconnected, repairing major leakage sites, and manually applying sealants to all visible and accessible leaks and joints. Cost-effective energy savings have been demonstrated from this technology approach in multiple field tests sponsored by the U.S. Department of Energy (DOE) in a range of climates.

DOE and Aeroseal, Inc., have jointly developed an advanced technology using an aerosol-spray sealant to decrease the amount of diagnostic work needed to identify leakage sites and to increase the amount of leakage sites sealed at reduced costs. The aerosol-spray equipment measures the total leakage of the entire duct system (supply and returns) before and after sealing in a manner similar to that for the conventional, best-practice approach. The aerosol spray is applied inside the ducts using the automated aerosol-spray equipment. This allows cracks up to $1 / 2$ in. in width (and possibly wider) to be sealed without the need to directly access the leaks. Before or while the aerosol spray is applied, major leaks like disconnected ducts and open return plenums are repaired manually using conventional approaches. This technology has the potential to reduce diagnostic and repair times, as the locations of minor leaks do not need to be identified, and wall, ceiling, and floor cavities do not need to be opened to gain access to these leakage sites. In addition, small leakage sites that could not be sealed manually before can be sealed with this technique.

A field test of the aerosol-spray technology and the conventional, best-practice approach to duct sealing was performed in the winter of 1999-2000. The field test involved 80 homes eligible for the DOE Weatherization Assistance Program in five states: Iowa, Virginia, Washington, West Virginia, and Wyoming. All the houses were single-family, site-built homes (no mobile homes) heated by a central forced-air gas or oil furnace. The field test was performed to determine the efficacy and programmatic needs of the duct-sealing technologies as applied in Weatherization Assistance Program homes and to support the U.S. Department of Housing and Urban Development's (HUD's) Partnership for Advancing Technology in Housing (PATH) in speeding the widespread use of the advanced duct-sealing technologies, especially the aerosol-spray approach, in the nation's housing.

The study found that duct leakage problems in homes eligible for the Weatherization Assistance Program are prevalent and perhaps worse than in the general population of homes. The average duct leakage of 500-600 cfm 25 measured in the field test homes is larger than the average leakages found in many other studies of non-low-income homes.

Although both the best-practice and the aerosol-spray technologies are successful at sealing leaks in ducts, the aerosol-spray technology combined with manual sealing of large leaks is more effective at sealing duct leaks by $50 \%$ or more compared with use of the best-practice approach alone. When the aerosol-spray technology was used to seal small leaks while major leaks were sealed manually, between 60 and $70 \%$ of the total duct leakage, on average, could be sealed, whereas only about 40 to $50 \%$ of duct leakage was sealed when manual methods alone were employed. Duct leakage reductions were also more consistent and more predictable in the houses receiving the aerosol-spray 
treatment than in those receiving best-practice duct sealing alone. Pressure pan readings further support these findings.

An average savings of 5\% was measured in space-heating energy use from the duct sealing performed in this field test. However, in homes where the ducts were clearly located outside the conditioned space of the home (i.e., in insulated attics or carports) rather than inside the home or in spaces partially connected to the conditioned space of the house (i.e., basements and uninsulated crawlspaces), the measured space-heating energy savings is nearly twice the average value, or about 9\%. Scatter in the energy usage data are too great to measure the difference in energy savings between the two duct-sealing methods. However, the larger air leakage reductions measured in the homes using the aerosol-spray technology would be expected to translate into higher energy savings compared with the homes using just the best-practice approach.

The aerosol-spray technology can potentially reduce labor time associated with just sealing the ducts by $70 \%$, or almost 4 crew-hours. The average time to seal ducts using the aerosol-spray technology was $98 \mathrm{~min}$, and one person could operate the equipment and perform the necessary manual sealing during this time period. The best-practice approach took an average of $147 \mathrm{~min}$ and required 330 crew-minutes. The material costs associated with both methods are about the same. Setup, teardown, and diagnostic times must also be considered in determining the overall or total labor costs associated with a particular duct-sealing method. These times could not be determined from the field test. Although times to perform these tasks are probably greater for the aerosol technology than for the conventional, best-practice technology, the difference is not likely to offset the four additional crew-hours needed to seal the ducts under the best-practice approach.

The five weatherization agencies that participated in the field tests were given a questionnaire to obtain their feedback on the technologies used in the tests. Three of the four responding agencies felt that the aerosol-spray technology was superior to the best-practice approach, although they recognized that it was not the correct tool for all applications. Implementation issues raised by the agencies included equipment costs, equipment size, and the existing software used to operate the equipment. The agencies also generally saw some value in making duct leakage measurements in addition to just pressure pan readings as part of the best-practice approach, although a strong consensus was not reached.

Duct sealing using the best available method should continue to be a recommended weatherization measure. Continued training on conventional, best-practice approaches is needed to achieve better duct leakage reductions and lower post-retrofit duct leakage rates than those observed in this field test. Training should also promote more consistent results among agencies and perhaps faster installation times.

Because of the benefits observed in this field test - namely, better and more consistent air leakage reductions and lower repair times compared with conventional, best-practice technologies alone - as well as the positive input received from the participating weatherization agencies, we recommend further study to encourage and promote use of the aerosol-spray technology within the Weatherization Assistance Program. A pilot test of full-production weatherization programs using the aerosol-spray technology is recommended to develop approaches for integrating this technology with other energy conservation measures and minimizing impacts on weatherization agency logistics. Implementation approaches that allow aerosol-spray duct sealing to be performed while other measures such as air sealing and side-wall insulation are installed must be established. The potential time savings of the automated aerosol-spray technology, which could allow crews to work on other tasks while the sealing takes place, needs to be verified. The need for speciality crews to perform 
duct sealing because of required skill levels and considerations of equipment cost and hauling must be determined.

In order to allow or improve adoption of the aerosol-spray technology within the Weatherization Assistance Program, four issues identified during the field test and raised by the participating weatherization agencies need to be addressed:

- The franchise structure and equipment/franchise costs established by Aeroseal, Inc., which holds an exclusive license to use this technology on residential and small commercial buildings, is likely to prohibit widespread adoption within the Weatherization Assistance Program. DOE should discuss with Aeroseal how costs could be reduced and the franchise approach and requirements altered to speed adoption of this technology in the Weatherization Assistance Program. DOE should investigate to what extent it is bound by Aeroseal's exclusive licensing agreement, since DOE and the U.S. government helped fund the initial development of the technology.

- The software used in the field test to control the equipment was developed by Aeroseal for use by HVAC contractors in its franchise approach. DOE should discuss the development of a considerably scaled-down and simplified version of this software with Aeroseal for use within the Weatherization Assistance Program.

- Aeroseal has stated that aerosol sealing "has been tested by Underwriters Laboratories Inc. (UL) and the Indoor Environment program at Lawrence Berkeley National Laboratory." DOE should further investigate and document the safety of this product before recommending full-scale implementation within the Weatherization Assistance Program.

- The agencies used in the field test were experienced in basic duct diagnostics (primarily pressure pans) and manual duct sealing and, in some cases, were state trainers themselves. As less experienced crews are trained on the aerosol-spray technology, the training program should be more extensive than the three-day training provided under this field test and should include a field monitoring component to provide immediate feedback to the newly trained crews.

Finally, application testing of the aerosol-spray technology in mobile homes is recommended. The Weatherization Assistance Program is serving more and more mobile homes each year, and mobile homes are the predominant house type served by many weatherization agencies. The aerosol-spray technology has been tested in mobile homes only on a very limited basis, and this field test addressed application of this technology to site-built, single-family homes only. 



\section{ABBREVIATIONS AND ACRONYMS}

$\begin{array}{ll}\text { ASAP } & \text { Achieved Savings Assessment Program } \\ \text { CEE } & \text { Center for Energy and Environment } \\ \text { DOE } & \text { U.S. Department of Energy } \\ \text { HUD } & \text { U.S. Department of Housing and Urban Development } \\ \text { HVAC } & \text { heating, ventilating, and air-conditioning } \\ \text { LBNL } & \text { Lawrence Berkeley National Laboratory } \\ \text { PATH } & \text { Partnership for Advancing Technology in Housing (HUD) } \\ \text { SIR } & \text { savings-to-investment ratio } \\ \text { TRAIN } & \text { Teaching, Rehabilitating, Aiding Iowa's Needy }\end{array}$





\section{INTRODUCTION}

\subsection{BACKGROUND}

According to Lawrence Berkeley National Laboratory data, existing air distribution (duct) systems are typically only 50-75\% efficient due to a combination of air leaks and thermal losses. The current best practice to reduce air leakage in duct systems is a two-step process. The first step is to quantify the leakage (air flow rate in cubic feet per minute $[\mathrm{cfm}]$ needed to pressurize the ducts to $25 \mathrm{~Pa}$ ) and identify the leakage sites using a combination of blower-door testing, duct pressurization via a duct blower, and duct pressure measurements. The second step is to manually reconnect ducts and seal identified leakage sites using mechanical fasteners (screws, clamps, etc.), duct materials (sheet metal, duct board, drywall, plywood, rigid board insulation, etc.), and sealants (mastic, spray foams, caulk, etc.). Cost-effective energy savings have been demonstrated from these technologies in multiple field tests in a range of climates.

Aerosol-spray sealants are an advanced technology developed to decrease the amount of diagnostic work needed and increase the number of leakage sites sealed at reduced costs. The aerosol spray is applied inside the ducts using automated equipment. This allows cracks up to $1 / 2$ in. in width (and possibly wider) to be sealed without the need to have direct access to the leaks. Before or while the aerosol spray is applied, major leaks like disconnected ducts and open return plenums are repaired manually using conventional approaches. This technology has the potential to reduce diagnostic and repair times because the locations of small leaks do not need to be visually identified, and wall, ceiling, and floor cavities do not need to be opened to gain access to these leakage sites. In addition, small leakage sites that could not be sealed manually before can be sealed with this technique.

Aerosol-based duct sealing has been identified by Nadel et al. (1998) as a high-priority emerging technology that, if adopted, could lead to substantial energy savings. The aerosol spray technology has been used in the field as part of the development process (Modera et al. 1996) and has been included in a utility-based program in California (Kallett et al. 2000), but it has not been implemented routinely within the U.S. Department of Energy's (DOE's) Weatherization Assistance Program or other efficiency programs in varying climates.

\subsection{PROJECT OBJECTIVES}

The purpose of this project was to determine through field testing the efficacy of advanced ductsealing technologies in housing weatherized by the Weatherization Assistance Program and to assess the training and material requirements needed to implement these advanced technologies within the program (provided they proved to be effective). In accomplishing these objectives, this project would support the U.S. Department of Housing and Urban Development's (HUD's) Partnership for Advancing Technology in Housing (PATH) in speeding the widespread use of advanced duct-sealing technologies and especially the aerosol-spray approach in order to radically improve the quality, durability, energy efficiency, environmental performance, and affordability of the nation's housing. 



\section{DUCT-SEALING TECHNOLOGIES USED IN THE FIELD TESTS}

In this field test, two approaches to sealing ducts in houses were studied: a conventional, bestpractice approach using simple diagnostics and manual sealing augmented by advanced diagnostics, and an approach using an aerosol-spray technology.

\subsection{CONVENTIONAL, BEST-PRACTICE DUCT-SEALING TECHNOLOGY}

Currently, most Weatherization Assistance Program agencies that include duct sealing as a conservation measure use pressure pan and, less frequently, dominant duct leakage measurements to determine if duct sealing is needed and to help locate duct leakage sites. The leaks identified through these measurements as well as leaks identified from visual inspection of obvious or potential leakage sites are sealed manually.

Pressure pan measurements are usually made by using a blower door to depressurize the house to $50 \mathrm{~Pa}$ relative to the outside. To make the measurements, supply and return registers are temporarily blocked off one at a time (typically by a shallow pan), and the pressure difference across each register is measured. Pressure pan measurements help identify and prioritize leakage sites. If the pressure difference is $<1.0 \mathrm{~Pa}$, any duct leaks are thought to be distant from the measured register. A larger pressure difference (2-5 Pa or more) indicates a duct leak near the register. Thus, pressure pan measurements help find leaks hidden in walls and floors and can be used to provide feedback on progress. Some agencies also use the number of pressure pan measurements greater than a selected value (say 1.0 Pa) as an indicator of how tight the entire duct system is and whether any duct sealing is warranted.

The dominant duct leakage measurement is made by turning on the air handler fan and measuring the pressure difference in the main part of the house relative to the outside. If the pressure in the main part of the house becomes less than outside pressure, the measurement indicates that leaks in the supply ducts are larger than leaks in the return ducts. A positive pressure in the house indicates the reverse - that return leaks are dominant. If the pressure in the house does not change, then the amount of duct leakage in the house may be small, or supply leaks may be the same magnitude as return leaks.

Weatherization crews usually first repair and seal major leakage sites such as disconnected ducts, panned floor joists (missing end plates and poor joints), junctions between register boots and wall and floor surfaces, filter slots, and equipment panels. They then manually apply sealants to all remaining visible and accessible leaks and joints until measurements and/or experience dictate that no other leaks can be sealed cost-effectively. Materials used to fix or seal these leaks include mechanical fasteners (screws, clamps, etc.) for reconnecting ducts, duct materials (sheet metal, duct board, drywall, plywood, rigid board insulation, etc.) to repair major leakage sites, and sealants (mastic, spray foams, caulk, etc.), which are used for all applications.

In this field test, this basic approach was enhanced to form a best-practice approach by measuring the total duct leakage and duct leakage to the outside using a duct blower. A duct blower (essentially a smaller version of a blower door) is connected to the duct system and used to measure the flow through duct leaks. All registers are sealed, and the duct is typically pressurized to $25 \mathrm{~Pa}$ with respect to the house and outside so that the total duct leakage is measured (reported in units of $\mathrm{cfm} 25$ ). Total duct leakage includes both leaks to the outside of the house as well as to the inside conditioned space. 
The duct leakage to the outside can also be measured by pressurizing the house to $25 \mathrm{~Pa}$ with respect to the outside using the blower door and pressurizing the ducts to $25 \mathrm{~Pa}$ with respect to the outside using the duct blower. Because there is no pressure difference between the house and the ducts, all the flow through the duct blower is through leaks to the outside.

Including the total duct leakage of the duct system in the best-practice approach, especially the amount that leaks just to the outside, is a powerful tool when combined with the other diagnostics and the weatherization crew's experience. Crews can use the initial direct measurements to help determine when duct sealing is warranted, rather than relying on indirect or anecdotal information from pressure pan and dominant duct leakage test. The magnitude of the duct leakage can also forewarn crews that big leaks in the system may be expected. Measuring the duct leakages at the end of the sealing work allows crews to decide if the system has been sufficiently tightened and whether any big leaks might have been missed.

\subsection{AEROSOL-SPRAY TECHNOLOGY}

The aerosol-spray technology involves a solid sealant that is suspended in an aerosol spray. This is sprayed into the ducts, where it seeks out and seals cracks that are $1 / 2$ in. or less, although larger leaks can be sealed in some cases if given enough time. The technology consists of an injector, largediameter flexible plastic tubing to connect the injector to the duct system, foam plugs to temporarily seal registers and protect heat exchanger surfaces in the indoor air handler unit, and computer software to operate the equipment. The equipment used in the field test was manufactured by Aeroseal, Inc., which holds the exclusive patent rights to the technology.

The injector (Fig. 2.1) consists of a blower, heater, and sprayer. The sprayer injects a mixture of water, sealant, and solvent into an airstream created by the blower. The heater is used to control the temperature of the air so that the water and solvent are evaporated from the mixture, leaving just the

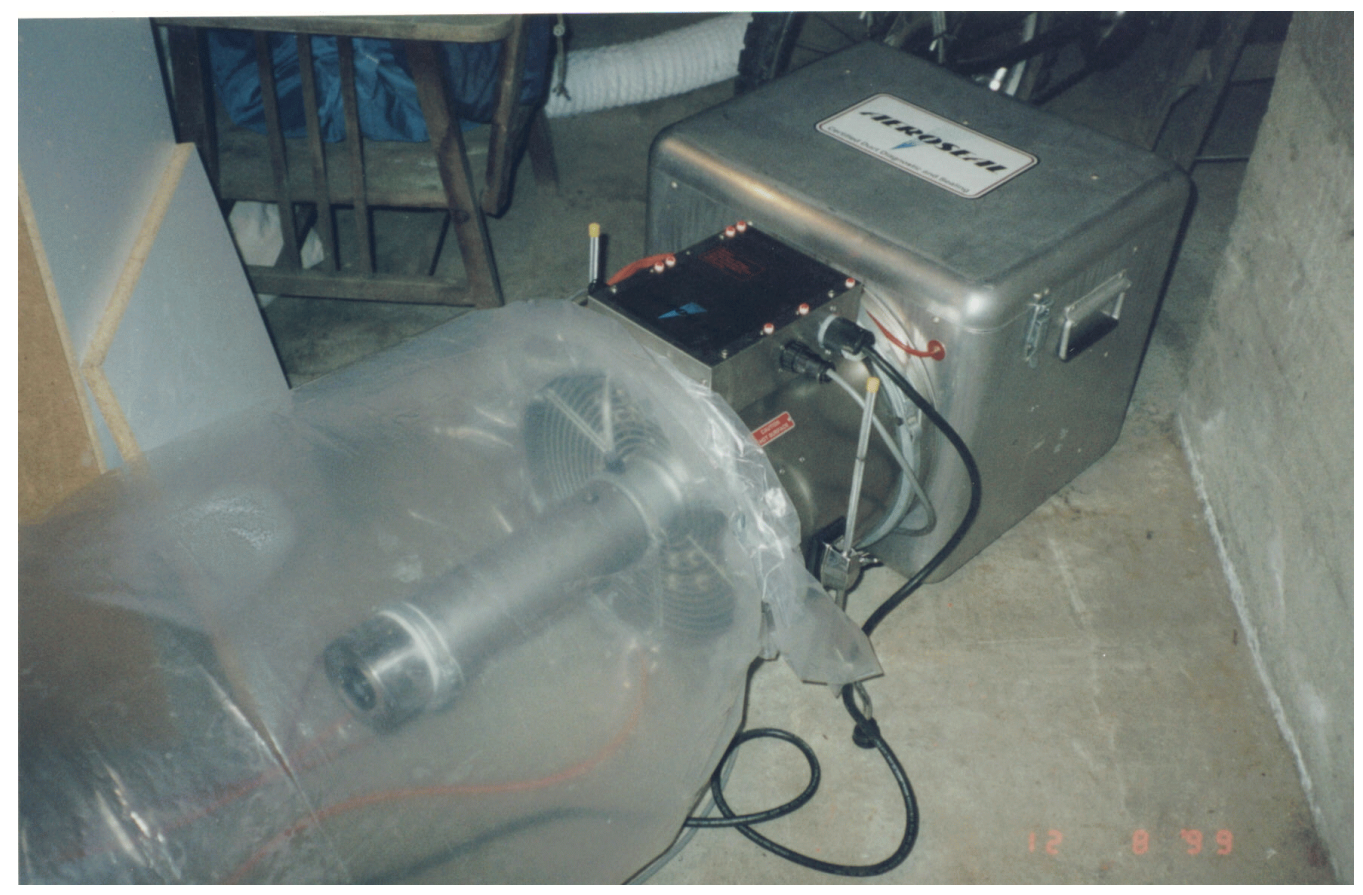

Fig. 2.1. The Aeroseal injector. 
sealant suspended in the air stream in solid form. This sealant-laden air is delivered into the duct system by the plastic tubing (Fig. 2.2), and the solid sealant particles are deposited at the leakage sites as air exits through the leaks. The blower is calibrated so that it can measure duct leakage as described in Sect. 2.1 for a more traditional duct blower. Three electrical circuits are needed to operate the equipment: a $110-\mathrm{V}$ circuit to operate the blower, a $110-\mathrm{V}$ circuit to operate the sprayer and its compressor, and preferably a $220-\mathrm{V}$ circuit to operate the heater (a 110-V circuit can be used in many but not all applications).

The sealant is a vinyl acetate polymer (an ingredient sometimes used as a base in chewing gum) and was originally used to remove the smoky smell from ducts after a fire by coating the inside of the ducts. Only about 10-20 oz of sealant is used in a typical home. For air-sealing applications, the aerosol-spray equipment is specially configured and designed so that the sealant fills the holes rather than lining the duct. The solvent used in the mixture is 2-ethyl 1hexanol. Aeroseal reports that this solvent is not designated as hazardous by the Occupational Safety and Health

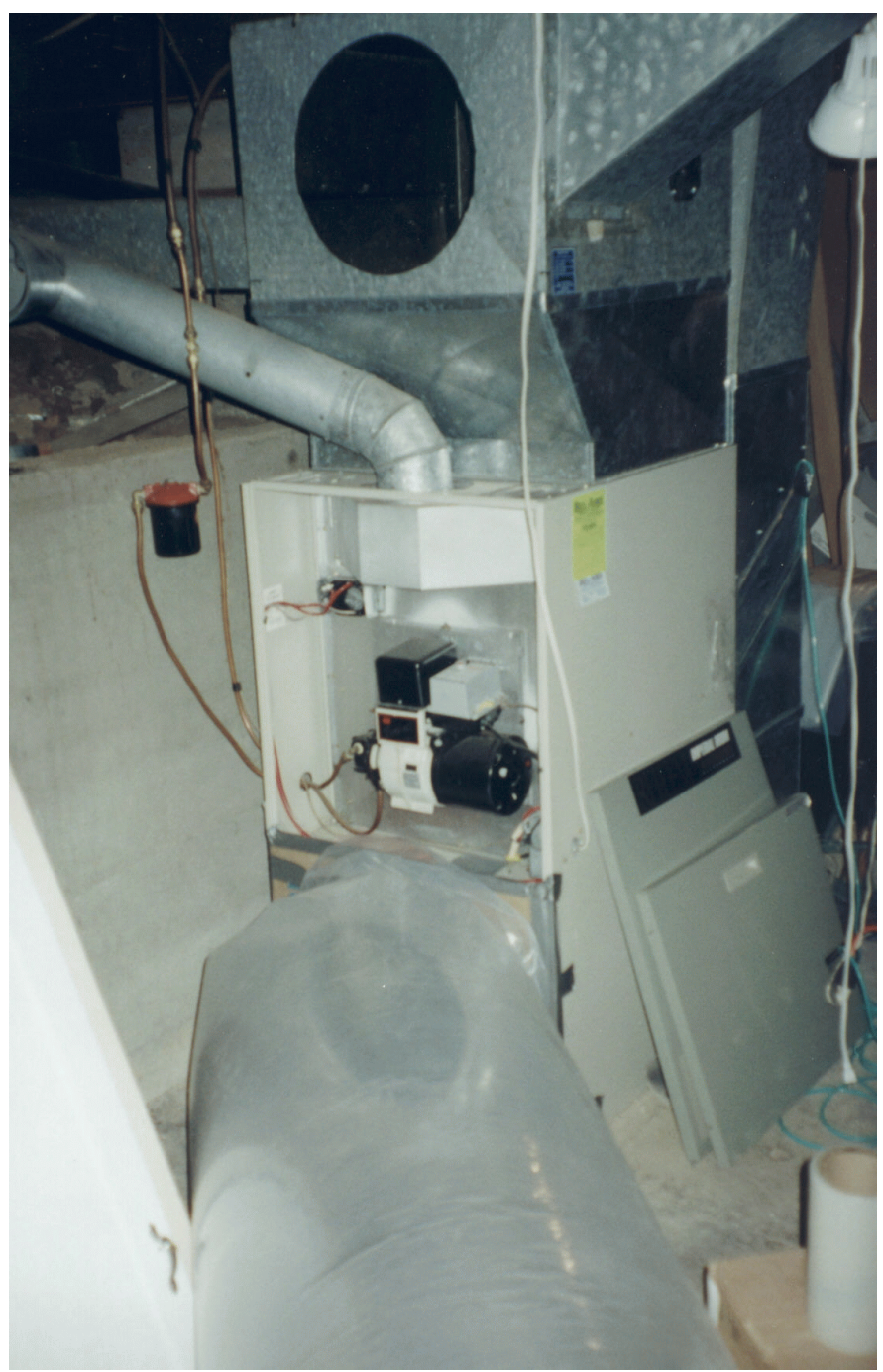

Fig. 2.2. The Aeroseal tubing connection. Administration.

The aerosol-spray equipment can be connected to the duct system in one of several ways:

- The typical approach is to cut a large hole (20- to 24-in.-diameter) in the supply or return duct near the air handler equipment and use a commercially available flange or collar to fasten the large-diameter plastic tubing from the injector to the duct system. (See the hole cut in the supply duct at the top of Fig. 2.2.)

- The plastic tubing can be connected to the air handler unit itself, as shown in Fig. 2.2. In this case, the air handler fan and cover are removed, a 20- to 24-in. hole is cut in a piece of cardboard or other similar material the same size as the fan cover, and the flange or collar is again used to fasten the plastic tubing to this cardboard blank, which is then temporarily taped to the air handler unit.

- The entire air handler unit can be removed, allowing the plastic tubing to be connected directly to the ends of the supply and return ducts.

- If needed, the plastic tubing can be connected to supply and return registers, although this is the least preferred method because supply registers are not very large. 
Once the aerosol-spray equipment is connected to the duct system and all registers are sealed with the foam plugs or by other means, the duct leakage of the entire system (both supply and return) is measured using the aerosol equipment following the same approach as discussed in Sect. 2.1. (The aerosol-spray equipment performs the same function as the duct blower.) Before the sealant is sprayed in, the heat exchangers in the air handler unit must be blocked off with the foam plugs, cardboard, or other materials so that sealant does not gum up these surfaces. This effectively isolates the supply ducts from the return ducts: only one-half of the duct system can be sealed before the equipment must be removed and connected to the other half of the duct system so that this other half can be sealed. The duct leakage is continuously monitored as the sealing occurs so that operators can gauge progress and determine when sealing should be stopped. When both the supply and return ducts are sealed, the heat exchanger is unblocked, and a final duct leakage measurement of the entire system is made. The aerosol-spray equipment is then removed. The final steps are to remove the foam plugs from the registers and air handler unit, cover and seal any holes cut in the ducts with sheet metal and mastic, reinstall fans and covers, and reinstall any air handler units that were removed.

The aerosol-spray technology shares some common elements with the conventional, best-practice approach described in Sect. 2.1.

- The aerosol-spray technology still requires manual sealing of major duct leakage sites. The aerosol-spray approach cannot reconnect ducts or seal large openings such as end plates missing from panned floor joists. When the aerosol-spray sealing process begins, the equipment will shut down and/or notify the equipment operator if a large leak is present.

- Although the aerosol-spray technology might be able to seal leaks $1 / 2 \mathrm{in}$. or larger if given enough time, it is most effective in sealing cracks less than $1 / 4$ in. To improve effectiveness and to ensure timely sealing of these large leaks, it is recommended that $15-30 \mathrm{~min}$. be spent sealing these larger leaks by hand while the aerosol-spray equipment seals the rest of the duct system to help the aerosol-sealing process along.

- In some duct systems, it can be more effective to seal a portion of the system by hand while the aerosol-spray equipment seals the rest of the system automatically. A duct system with a short return or one in which it is difficult to connect a portion of the system to the equipment is a good candidate for this approach.

- The foam seals used to block off the registers during the sealing process are placed inside the ducts such that the junction between register boots and wall and floors are not sealed automatically. While the aerosol-spray equipment is operating, these leakage sites need to be sealed by hand.

- The aerosol-spray technology measures duct leakage before and after sealing, providing the same information and feedback as explained in Sect. 2.1 from using the duct blower.

Thus, perhaps a better way of viewing the aerosol-spray technology is as another tool to be used in a comprehensive approach to duct sealing rather than as a separate approach to the conventional technology. Once major duct leaks are sealed, a determination can be made as to whether further duct sealing should be done manually using conventional methods, automatically using the aerosol-spray technology, or not at all.

The operation of the aerosol-spray equipment is controlled by a Window-based software program operating on a portable personal computer. The software was developed by Aeroseal for privatesector heating, ventilating, and air-conditioning (HVAC) contractors to market, diagnose, and perform duct sealing using the aerosol-spray technology. The software is designed to be used in two phases. In the first phase, a salesman uses the software and simple diagnostic equipment (not the 
injector itself) to determine the need for air sealing and to sell a client on a job. In addition to performing a simple duct leakage analysis using methods other than those described in this report, the software performs other tests and diagnostics to check on room air flow and air distribution throughout the house, register temperatures and the need for duct insulation, total air flow and the need for a larger return system, and health and safety. The software also collects household and house information needed to sell, cost, and plan an air-sealing job.

If a job is sold, an air-sealing crew returns at a later date to implement the second phase. In this second phase, the Aeroseal equipment is installed to seal the ducts. The software is used to operate the equipment and collect data throughout the sealing process. As part of Aeroseal's licensing arrangements with its HVAC contractors, data collected by the contractors on air-sealing jobs must be transferred to Aeroseal on a periodic basis for quality control reasons or the software will fail to function.

Only portions of Aeroseal's software were needed for this field test. In addition, the data collection needed for this field test required a nonstandard use of the software. Nevertheless, this software package had to be used in the field test because there was insufficient funds or time to develop a customized version. 



\section{FIELD TEST DESCRIPTION}

This study of advanced duct-sealing methods applied within the Weatherization Assistance Program was performed by five weatherization agencies in five states. The study was performed over the winter of 1999-2000 and involved submetered field measurements of space-heating energy use and detailed duct performance measurements in 80 houses. Details of the field test design are presented in this section.

\subsection{EXPERIMENTAL DESIGN}

Five agencies implementing the Weatherization Assistance Program were selected to participate in this field test:

- Community Action of South Eastern West Virginia, Bluefield, West Virginia;

- Virginia Mountain Housing, Inc., Christiansburg, Virginia;

- Iowa East Central Teaching, Rehabilitating, Aiding Iowa's Needy (TRAIN), Davenport, Iowa;

- Wyoming Energy Council, Inc., Laramie, Wyoming; and

- the Opportunity Council, Bellingham, Washington.

These participants were selected from among 40 agencies in 19 states that had been identified by state Weatherization Assistance Program offices and regional DOE Weatherization Assistance program directors as potential candidates. The selection of these five agencies was based on their current knowledge and experience with duct sealing, ability to use advanced diagnostic equipment, potential to locate 16 houses meeting the study's selection criteria (see below), capacity to add the workload required of this field test to their current work, and general interest in the project. The geographical location of the agency was also important to ensure that houses would have sufficient heating loads that could be measured (cooling was not considered, as discussed below) and to minimize travel costs associated with planned training sessions. Thus, these agencies were not selected randomly and do not represent the typical weatherization assistance program agency; rather, they were carefully chosen to ensure the successful completion of the field test so that the performance of the advanced duct-sealing measures could be determined under the best conditions possible.

As shown in Fig. 3.1, the agencies were located in three climate zones: a cold climate as represented by Iowa and Wyoming (6408 and 7381 heating degree days and $-3^{\circ} \mathrm{F}$ and $0{ }^{\circ} \mathrm{F} 99 \%$ design temperatures, respectively), a mild heating climate with a mild design temperature as represented by Washington ( 5515 heating degree days and $21^{\circ} \mathrm{F} 99 \%$ design temperature), and a mild heating climate with a more severe design temperature than Washington as represented by Virginia and West Virginia (4150 and 4476 heating degree days and $17^{\circ} \mathrm{F}$ and $12^{\circ} \mathrm{F} 99 \%$ design temperatures, respectively).

Each of the participating agencies selected 16 houses for the field test, principally using their current waiting list to do so. Houses selected for the field test had to be single-family homes eligible to receive benefits from the Weatherization Assistance Program, had to have an air-distribution (duct) system used for space heating, and had to have a central gas or oil furnace. The field test did not include mobile homes because the aerosol-spray duct-sealing technology had not been previously tested on this type of home. Many of the weatherization agencies contacted for participation in this 


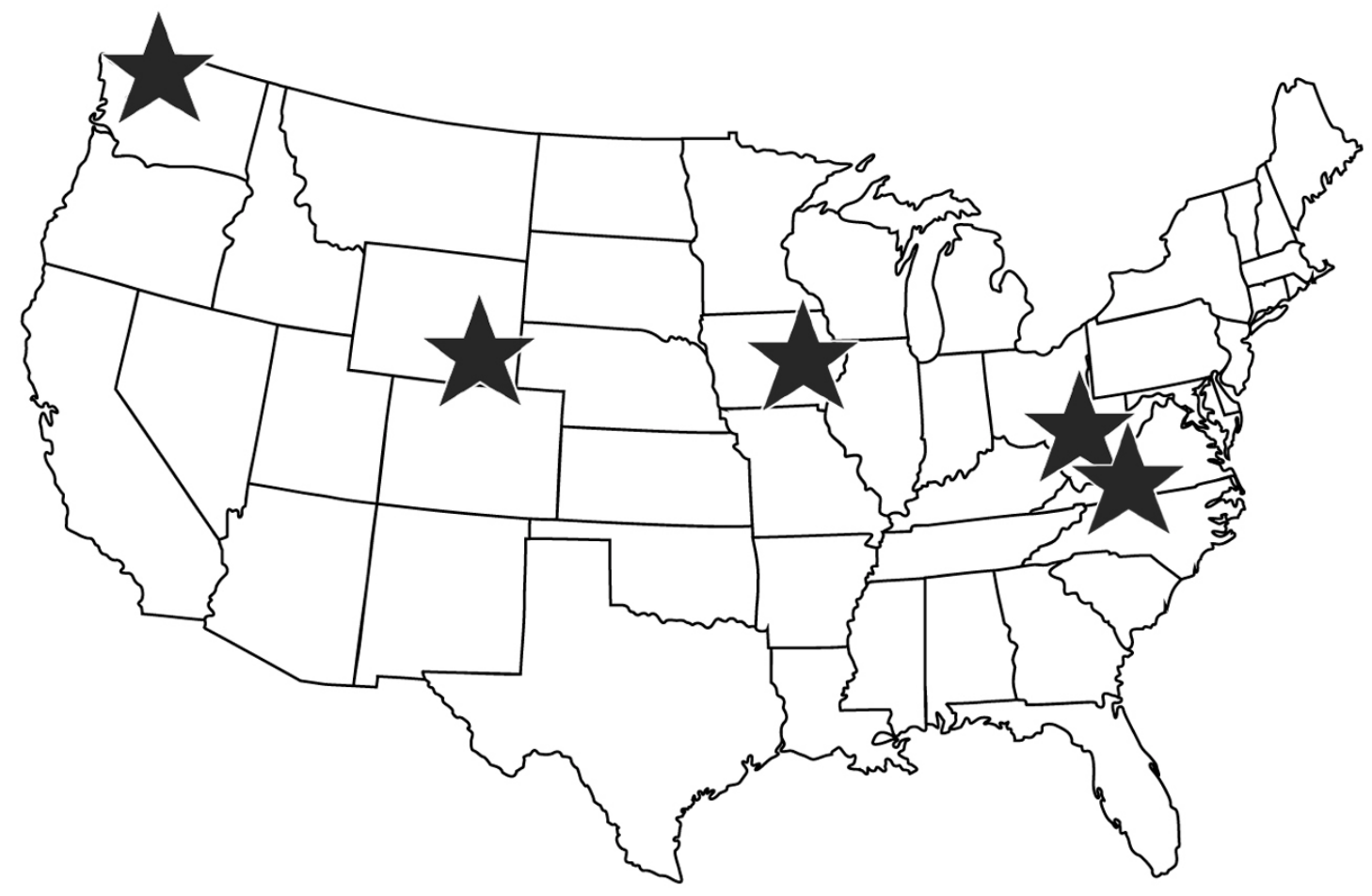

Fig. 3.1. Location of the five weatherization agencies participating in the study.

field test expressed a need for additional guidance on duct sealing in mobile homes. The field test also did not address homes in the South or air-conditioning savings from duct sealing for several reasons:

- Available funding could not support the installation of metering on air conditioners to measure electricity savings.

- Air-conditioning in Weatherization Assistance Program houses is usually provided by window units rather than central systems requiring ducts.

- Heating in Weatherization Assistance Program homes in the South is usually provided by space heaters and other non-central systems that do not require ducts.

- It would be hard to measure changes in heating energy use in homes located in the South because of the smaller heating loads.

- Few agencies in southern states were nominated as candidates for the field test.

A split-winter experimental design was used in the field test. Pre-retrofit space-heating energy use was measured in the first half of the 1999-2000 winter starting in November 1999. Duct sealing was performed in January 2000, allowing post-retrofit space-heating energy use to be measured for the remainder of the winter, ending in March 2000. Duct sealing was the only weatherization measure performed on the houses during the field test. Starting in April 2000, the agencies returned to the houses to perform other weatherization measures as dictated by their respective weatherization programs.

Eight houses at each agency were assigned to receive duct sealing using the conventional, bestpractice approach and the other eight houses were assigned to be sealed using the aerosol spray approach. These assignments were made randomly after stratifying the houses at each agency 
primarily on the basis of foundation type and duct location. For example, if Agency A had eight houses with a basement foundation and ducts in the basement, four houses with a crawl space foundation and ducts in the crawl space, and four houses with a crawl space foundation and ducts in the attic, then half of the houses in each of these three groups (four, two, and two, respectively) were assigned to the best-practice group and half to the aerosol-treated group. Foundation type and duct location were characteristics that could impact achieved duct leakage reductions and energy savings and that could be easily assessed while homes were being signed up. These assignments were made in late December 1999 (just before the retrofit work was to be performed) to reduce any bias and to handle attrition to the fullest extent possible.

All homes in the field test received duct sealing following either the best-practice or aerosol approaches. A control group of houses was not included in the field test to try to account for energy savings resulting from sources other than duct sealing such as occupant response to changing fuel costs and changing indoor temperatures.

\subsection{DATA PARAMETERS AND INSTRUMENTATION}

The data collected for this study were of three types: time-sequential data, point-in-time measurements, and survey information. The time-sequential data measured space-heating system energy use, the point-in-time measurements quantitatively assessed the duct system and related components immediately before and after duct sealing was performed, and the survey information described important characteristics of the house.

\subsubsection{Time-Sequential Measurements}

The Achieved Savings Assessment Program (ASAP) (Minnesota Office of Low-Income Energy Programs 1998; Bohac, Linner, and Dunsworth 1996) was used to measure space-heating energy use before and after duct sealing. Under ASAP, Pacific Science \& Technology time-of-use CT loggers were installed by staff from the five agencies participating in the field test to record the start and stop times of the space-heating system burners by placing the current transformer around the appropriate gas valve or oil-burner control wire for each home. Agency personnel then used Pacific Science \& Technology SmartWare software to retrieve the recorded data several times during the field test.

The DESLog software program developed for ASAP was then used to estimate annual pre- and postretrofit space-heating energy use and savings for each house. Daily run times were calculated using the recorded start/stop times and multiplied by the metered heating system input rate to calculate the daily space-heating energy use. Using weather data collected by the National Climatic Data Center, regressions were performed for each house to develop equations showing how daily space-heating energy use varies with outdoor temperature before and after retrofit. Normalized annual pre- and post-retrofit energy consumptions were then calculated using the regression equations and long-term average weather data, allowing a normalized annual energy savings to be calculated for each house.

In performing these analyses, DESLog automatically checked the quality of the data and the regression models to ensure that the results were reliable. Checks included looking for days with zero energy use, identifying houses with unrealistic reference temperatures (outdoor temperature at which the house needs no space heating) and heating slopes (declines in energy use as outdoor temperature increased), and examining regression coefficients and coefficients of variance. Manual, visual checks of the data and results were also performed. 
Reliable models could not be developed for ASAP analysis for the houses in Washington state because of the limited variation in daily outdoor temperature during the monitoring period. Daily average outdoor temperatures ranged from 34 to $54^{\circ} \mathrm{F}$ and were predominantly between 40 and $50^{\circ} \mathrm{F}$ in Washington, whereas they varied from $\sim 10$ to $60^{\circ} \mathrm{F}$ in Wyoming and from 20 to $60^{\circ} \mathrm{F}$ in Virginia. Consequently, we used an alternative analysis approach for the Washington houses.

For each house in Washington, we first selected a set of pre-retrofit days and a set of post-retrofit days that had similar outdoor temperatures. (The number of days selected for the pre-retrofit period were not necessarily equal to the number of days selected for the post-retrofit period.) Days were selected such that the average outside temperature for the selected pre-retrofit days was as close as possible to the average outside temperature for the selected post-retrofit days. Days with an average outdoor temperature that was much lower or higher than those occurring in the other period were not selected. The difference in average outside temperature between the pre- and post-retrofit periods for any given house ranged from 0.022 to $1.571^{\circ} \mathrm{F}$.

Once the days for each house were selected, average pre-and post-retrofit daily space-heating energy uses (in therms per day) were calculated using the energy use data collected on these selected days. Normalized annual pre- and post-retrofit energy consumption for each house was then calculated using the following equation:

Normalized annual energy consumption $=\left[\right.$ daily av energy use $/\left(65^{\circ} \mathrm{F}-\right.$ av outside temperature $\left.)\right] \times 4598.98$,

where the daily average energy use and the average outside temperature are for the selected days and 4598.98 represents heating degree days base $65^{\circ} \mathrm{F}$ for Seattle, Washington.

As a check on whether the alternative method accurately estimated annual energy usage, reliable preretrofit ASAP results for six houses were compared with results from the alternate method. As shown in Table 3.1, the average energy use results estimated by both methods for the six houses are within $5 \%$ of each other. As can be seen in Fig. 3.2, the difference in energy use for individual homes is highly correlated with the difference in the reference temperature calculated by ASAP and the constant $65^{\circ} \mathrm{F}$ assumed in the alternative method.

\subsubsection{Point-in-Time Measurements}

Measurements were made immediately before and after the ducts were sealed in each house to determine the immediate impact of duct sealing. Using the data collection forms and procedures shown in Appendix A, data were collected on the house air leakage, pressure pan measurements, house and dominant duct leakages, combustion safety, duct operating pressures, and duct leakage. One set of forms and procedures were used for the houses receiving conventional, best-practice duct sealing and a second set for houses receiving aerosol-spray duct sealing. While the two sets of forms and procedures collected the same information, they differ slightly because a pressure meter and a duct blower were used to collect the house and dominant duct leakage data and the leakage rates of the ducts themselves in the houses receiving the best-practice treatment, whereas the aerosol-spray equipment collected these data in the houses receiving aerosol duct sealing. 
Table 3.1. Comparison of results from ASAP analysis and an alternative analysis method

\begin{tabular}{|c|c|c|c|c|c|c|c|}
\hline \multirow[b]{2}{*}{ Site } & \multicolumn{4}{|c|}{$\begin{array}{c}\text { Normalized pre-retrofit energy use } \\
\text { (therms) }\end{array}$} & \multicolumn{3}{|c|}{$\begin{array}{l}\text { Reference temperature } \\
\left({ }^{\circ} \mathbf{F}\right)\end{array}$} \\
\hline & ASAP & $\begin{array}{l}\text { Alternative } \\
\text { method }\end{array}$ & Difference & $\begin{array}{c}\% \\
\text { difference }\end{array}$ & ASAP & $\begin{array}{l}\text { Alternative } \\
\text { method }\end{array}$ & Difference \\
\hline WA01 & 323 & 296 & 27 & 8 & 68.1 & 65 & 3.1 \\
\hline WA02 & 627 & 545 & 82 & 13 & 71.5 & 65 & 6.5 \\
\hline WA08 & 539 & 537 & 2 & 0 & 65.8 & 65 & 0.8 \\
\hline WA12 & 275 & 318 & -43 & -15 & 60.0 & 65 & -5.0 \\
\hline WA13 & 657 & 649 & 8 & 1 & 65.9 & 65 & 0.9 \\
\hline WA16 & 775 & 695 & 80 & 10 & 69.9 & 65 & 4.9 \\
\hline Ave. & 533 & 507 & 26 & 5 & 66.9 & 65 & 1.9 \\
\hline
\end{tabular}

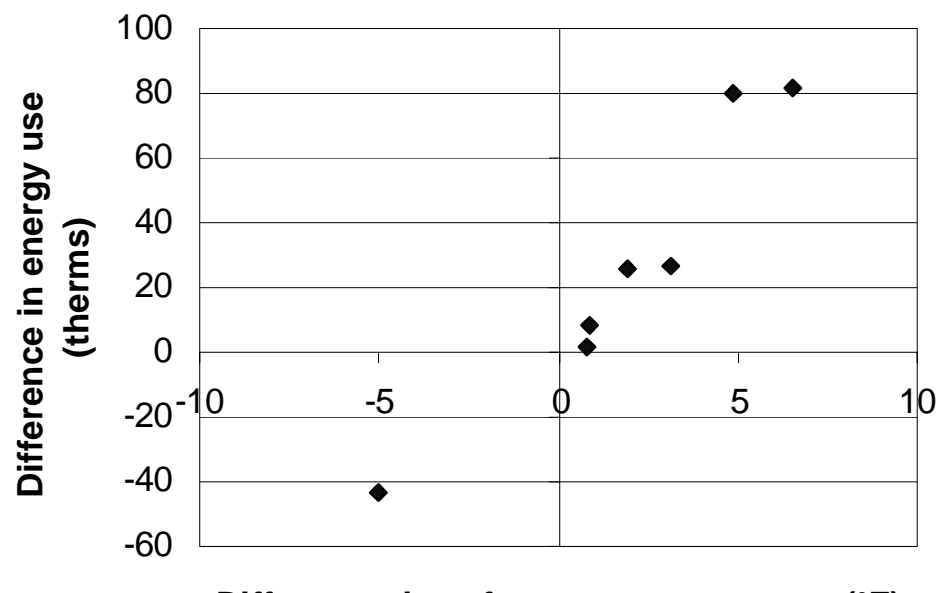

Difference in reference temperature $\left({ }^{\circ} \mathrm{F}\right)$

Fig. 3.2. The difference in energy use calculated by the ASAP and alternative analysis methods for a sample of houses as a function of the difference in reference temperature used in each model.

House air leakage measurements were made using a blower door. In houses with basements, two measurements were performed before and after retrofit: one with the basement door open so that the basement volume was included in the conditioned house volume and a second with the basement door closed and basement windows open so that the basement was outside the conditioned building envelope. If houses could not be depressurized to $50 \mathrm{~Pa}$, extrapolations were performed from the pressures that were obtainable to estimate house air leakages at $50 \mathrm{~Pa}$. 
Pressure pan measurements were made after depressurizing the house to $50 \mathrm{~Pa}$ with respect to the outside and measuring the zone pressures where the ducts were located. In a house with a basement, the basement was opened to the outside and isolated from the house in order that pressure pan readings of ducts in the basement could be made. (If the basement had been included with the house volume, most pressure pan readings would have been zero whether the ducts leaked or not.) In analysis of the pressure pan data, the direct measurements were not adjusted for zonal pressures $<50 \mathrm{~Pa}$. In most cases (estimated to be $80 \%$ or more), no adjustments were necessary. In the remaining cases where adjustments could have been made, it was usually not clear what zonal pressure to use. For example, ducts running from the basement to the second floor could be adjusted for the basement zone, the interior wall zone (which was not measured), or even the attic, depending on where the leak in the system occurred. Because before and after differences were of importance and the zonal pressures did not change before and after duct sealing, making somewhat arbitrary adjustments to the pressure pan readings was determined to be inappropriate.

Each agency generally followed its current, established procedures in performing combustion safety checks. For this field test, the intent of these measurements was to establish if a safety problem existed before or after duct sealing and to ensure that any safety problem observed was corrected before leaving the house.

Both total duct leakage and duct leakage to the outside were measured before and after retrofit. In these measurements, the duct leakage of the entire duct system (supply and return) was assessed separate measurements of supply leakage and return leakage were not performed. However, each measurement was made in two ways. The total duct leakage and duct leakage to the outside were first measured by pressurizing the supply ducts to $25 \mathrm{~Pa}$ (a pressure probe was placed in the supply duct), and then a second measurement was made by pressurizing the return ducts to $25 \mathrm{~Pa}$ (using a pressure probe placed in the return duct). These measurements can differ considerably if a major leak exists in either the supply or return. Both measurements were made to avoid requiring the agency crews to decide the best location to make the pressure measurement in the field. If ducts could not be pressurized to $25 \mathrm{~Pa}$, extrapolations were performed from the pressures that were obtainable to estimate duct leakages at $25 \mathrm{~Pa}$.

Duct leakages to the outside were measured by pressurizing the house and ducts to $25 \mathrm{~Pa}$, so that the only leakage in the ducts was to the outside. To make the outside leakage measurements in houses with basements, the basement was isolated from the rest of the conditioned volume of the house by closing the interior basement door, and a basement window or exterior basement door opened to connect the basement to the outside. This was done to avoid forcing the weatherization crews to decide whether a basement was inside or outside the conditioned volume while in the field and so that an "outside" measurement was made in every house. Other information was collected by the crews (see Sect. 3.2.3) so that this determination could be made during analysis. If the basement had been assumed to be inside the house, the duct leakage to the outside would usually have been zero.

\subsubsection{Survey Information}

Information on the house and duct leakage repairs performed were collected using the data forms provided in Appendix A. In addition to house information such as foundation type, number of stories, and floor area, detailed information on duct location, duct types, and presence of duct registers in basements were collected. Duct repair information included the time to perform the repairs, crewhours to perform manual repairs, estimated material costs, and a description of the major repairs made. In the houses receiving the aerosol treatment, the crew-hours to perform manual repairs 
excludes the crew-hours associated with setting up and operating the aerosol equipment to gauge the amount of manual repairs that still must be performed using this technology.

A questionnaire was also sent to all five agencies to gain their feedback on the training provided (see Sect. 3.3) and on how the technologies introduced during the field test could be implemented within the Weatherization Assistance Program. This questionnaire is provided in Appendix B.

\subsection{TRAINING}

Two training sessions were provided for the weatherization agencies on how to implement the field tests. One training session focused on installation of instrumentation and data collection to measure space-heating energy use, while the second training session addressed how to use the aerosol-spray equipment and collect the duct and survey field data.

The Center for Energy and Environment (CEE), which developed ASAP for the state of Minnesota, provided training on monitoring the space-heating system. Three one-day training sessions were provided in November 1999 - one each in Washington, Iowa (with Wyoming attending), and Virginia (with West Virginia attending). The first half of the day was spent in the classroom discussing installation of the CT logger, use of the SmartWare software to download recorded data, transferring electronic files to CEE for further analysis, and documenting dates (logger installation, data retrieval, etc.) on a tracking form. The afternoon was spent in the field actually installing CT loggers on two field test homes and reviewing the data recovery procedures.

The training on field data collection and air-sealing techniques was provided by Aeroseal (the manufacturer of the aerosol-spray equipment used in the field test) and Oak Ridge National Laboratory. Two four-day training sessions were provided in December 1999 - one in Washington (attended by Wyoming) and one in Virginia (attended by Iowa and West Virginia). The first day of this training reviewed the field data collection forms, especially how to make the duct leakage and pressure pan measurements and perform the combustion safety checks. The first training was performed in Washington, where many of these details were finalized during the training. The furnace training facility of Virginia Mountain Housing, Inc., was used extensively in the second training session to demonstrate the different duct leakage test procedures using that company's house mock-ups.

The remaining three days of the December training sessions focused on use of the aerosol-spray equipment. Classroom training was provided the first day to introduce the agencies to the equipment and the software - how to hook the equipment up and use the software to control it, and how to use the equipment and software to collect data. The remaining two days were spent in the field using the equipment to seal ducts in two non-field-test houses. 



\section{CHARACTERISTICS OF THE HOUSES IN THE STUDY}

The houses selected for the field test by the five participating weatherization agencies were identified primarily from the existing production schedules and waiting lists maintained by each agency. No effort was made to include houses with especially leaky ducts or houses with ducts located in specific locations. Thus, these houses are representative of typical weatherization-eligible houses with the characteristics identified in Sect. 3.1; namely, they are representative of houses with central heating systems and air distribution systems.

Although 80 houses were initially selected for the field test (40 for best-practice duct-sealing and 40 for aerosol-spray duct sealing), four houses were dropped from the study by the time the survey information was collected in January 2000 while duct repairs were made. Thus, the data reported here were gathered on 37 best-practice houses and 39 aerosol houses.

\subsection{ALL HOUSES}

The average floor area of the houses was 1,299 $\mathrm{ft}^{2}$. Houses with basements (including the basement floor area) were slightly larger than those without basements $\left(1,342 \mathrm{ft}^{2} \mathrm{vs} 1,262 \mathrm{ft}^{2}\right)$. The houses of Agency A had somewhat larger average floor areas than houses at the other four weatherization agencies. The average floor area for Agency A houses was $1,656 \mathrm{ft}^{2}$, while the average floor area in houses of the other four agencies ranged from 1,044 to $1,321 \mathrm{ft}^{2}$.

Most of the houses selected for the field test had either basements (46\%) or crawl spaces (33\%). Some houses had both (13\%), and just a few were built on a slab (8\%). Basements were very prevalent in Agency E (73\%), and crawl spaces were the primary foundation type in Agency D (57\%) and Agency C (69\%). Houses with slabs were limited to Agency E (13\%) and Agency B (25\%).

A majority of the houses had just one above-grade floor (61\%), with most of the remaining houses being either two-story (28\%) or a story and a half (11\%). Only one house had three stories. One-story houses were especially prevalent in Agency A (93\%); two-story houses were most common in Agency B (56\%).

The average age of the houses used in the study was 60 years. Houses in Agency A were the oldest (70 years old); houses were most recently built in Agency C (51 years old) and Agency A (54 years old).

Ducts were predominantly located in basements, crawl spaces, and inside the homes, consistent with the types of foundations found in the homes. As shown in Fig. 4.1, about $60 \%$ of the houses had ducts in basements, and about $40 \%$ had ducts in crawlspaces and inside the home. These percentages do not add to $100 \%$ because houses had ducts in multiple locations. Houses with more than one story usually had some ducts located inside the home, presumably to supply conditioned air to the upper floors. Ducts were always found in the basements of basement houses and usually found in crawl spaces when they were present. Ducts in houses built on slabs were located primarily inside the house and to a lesser extent in the attic. 


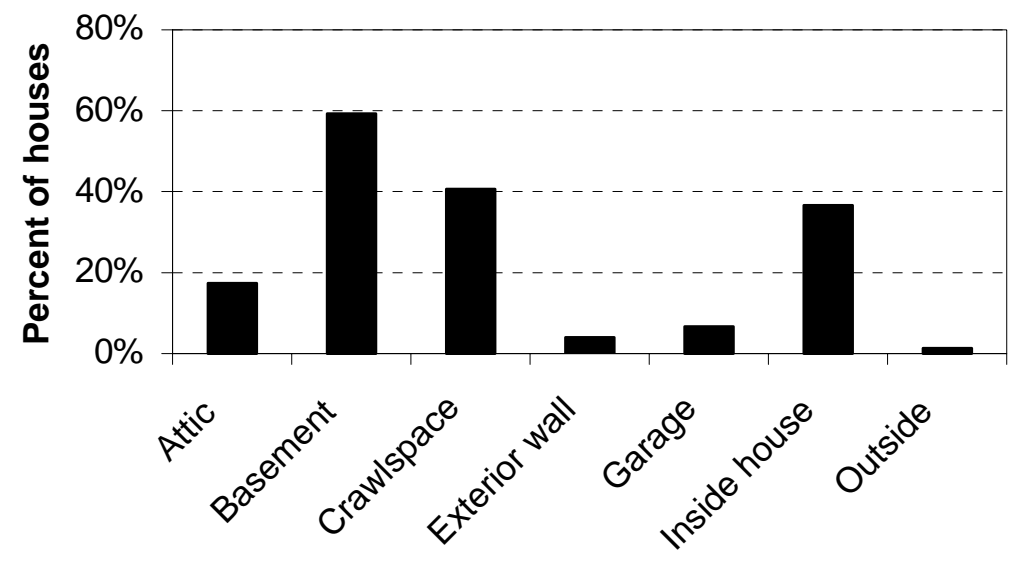

Fig. 4.1. Location of ducts in the field test houses.

As shown in Fig. 4.2, sheet metal ducts, flexduct, and ducts created by panning over the floor joist were commonly found in the field test houses. Duct board was not a common duct material in these homes.

The homes used in the field test were quite leaky. The average whole-house leakage rate of the homes was 3,962 cfm50, or 18 ach50. Basement homes included in this average were measured assuming the basement was part of the conditioned area of the house. (The basement door was opened during the measurements, and basement floor areas were included in calculating the ach50 values.) Homes were the leakiest in Agencies D and B (averages of 5,298 cfm50 and 5,889 cfm50, respectively) and tightest in Agencies C and A (2,541 cfm50 and 2,293 cfm50, respectively).

\subsection{COMPARISON BETWEEN BEST-PRACTICE AND AEROSOL HOUSES}

There were no major differences in the characteristics described above between the group of homes receiving conventional, best-practice duct sealing and those in which the aerosol-spray technology was used. This was expected because selected house characteristics were used to stratify the houses before they were randomly assigned to the two groups (see Sect. 3.1). This step was taken to ensure that the two groups of houses were equivalent for the characteristics considered and that differences observed in duct leakage reductions and other variables would not be due to differences in these characteristics between the two groups.

The best-practice houses were slightly larger than the houses receiving aerosol-spray treatment $\left(1,334 \mathrm{ft}^{2} \mathrm{vs} 1,267 \mathrm{ft}^{2}\right)$, but this difference is not statistically significant. The best-practice houses also had more crawl spaces than the aerosol group of houses (54\% vs 38\%) when houses with just crawl spaces and houses with basements plus crawl spaces were considered. The number of one-story and multistory homes was about the same for each group, as was their average age.

The location of ducts was similar between the two groups of homes with one minor exception ducts were located in a crawl space in about $50 \%$ of the best-practice houses but in only about $30 \%$ of the aerosol houses, principally because the best-practice group included more crawl space houses, 


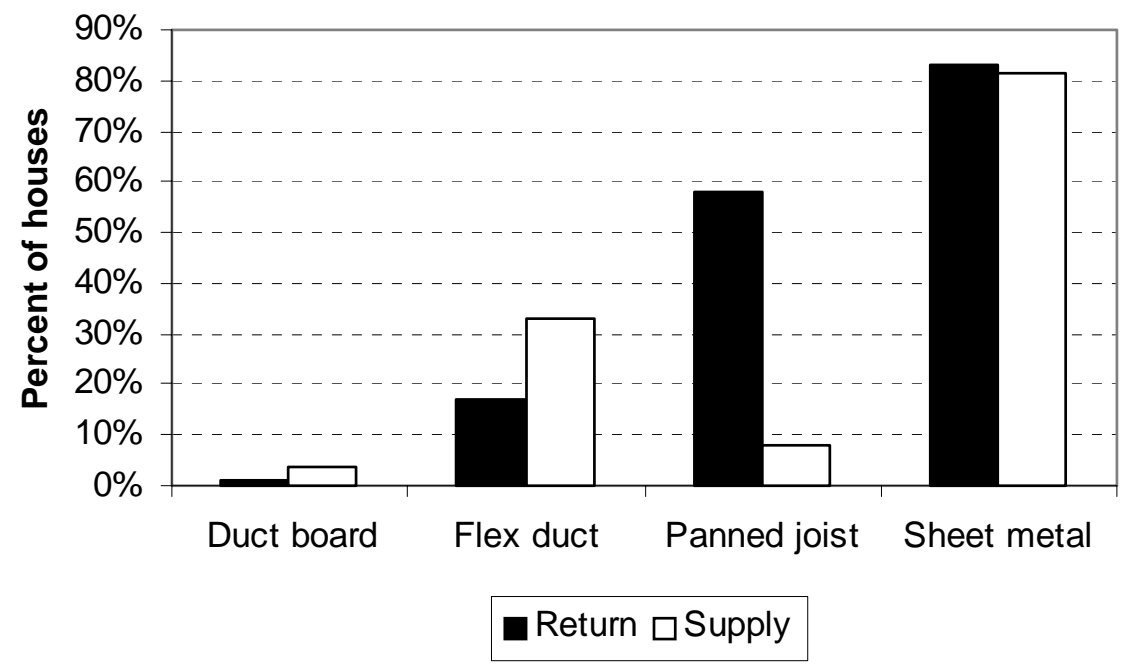

Fig. 4.2. Types of return and supply ducts found in the field test houses.

as discussed above. Little difference was observed between groups in the material used to make the ducts.

The best-practice houses were leakier on average than the aerosol houses $(4,215 \mathrm{cfm} 50 \mathrm{vs}$ $3,722 \mathrm{cfm} 50$ ), but this difference is not statistically significant. 



\section{DUCT LEAKAGES}

As discussed in Sect. 3.2.2, four different measurements of duct leakage were made in each house before and after ducts were sealed using either conventional, best-practice duct-sealing techniques or these techniques combined with the aerosol-spray technology. The measurements of duct leakage to the outside in basement houses as reported in this section were made with the basement isolated from the rest of the house and open to the outside in all cases, whether or not the basement might be considered conditioned or not. These values are reported (rather than assuming duct leakage to the outside is zero if the ducts were located in a conditioned basement) because the primary intent of the field study and the analyses presented in this section was to determine the difference in sealing capabilities of the two approaches.

Averages are based on fewer than 80 houses (the number of houses initially included in the field test) for several reasons. Some houses were eliminated from the sample due to normal attrition associated with moving, illnesses, and emergency repairs required to the space-heating systems. Other houses were eliminated from the data set because measurements were not made (e.g., time constraints required skipping some of the data collection; occupants requested that some measurement not be made to avoid dropping the interior temperature) or because measurements were determined to be unreliable (e.g., duct leakages to the outside were higher than the total duct leakage measurements).

\subsection{ALL HOUSES}

Table 5.1 summarizes the results of the duct leakage measurements for all the houses included in the field test. All four measurement approaches clearly indicate the positive impact duct sealing had on reducing duct leaks in the field test houses. On average, about half of the duct leakage could be sealed by the available techniques. The reductions in leakage, ranging from 302 to $375 \mathrm{cfm} 25$, are all statistically different from zero at the $95 \%$ confidence level. Analysis using median values confirmed the same general trends as the analysis using means (averages) - the magnitudes of the duct leakages and reductions were smaller, indicating that the samples were skewed to higher values, but the percentage reductions were approximately the same.

Table 5.1. Average duct leakage results for all field test houses

\begin{tabular}{|l|c|c|c|c|}
\hline \multirow{2}{*}{\multicolumn{1}{|c|}{ Parameter }} & \multicolumn{2}{c|}{ Total duct leakage $^{a}$} & \multicolumn{2}{c|}{ Duct leakage to the outside $^{a, b}$} \\
\cline { 2 - 5 } & Supply & Return & Supply & Return \\
\hline \hline Number of houses & 70 & 68 & 57 & 57 \\
\hline Pre-retrofit (cfm25) & 613 & 634 & 497 & 511 \\
\hline Post-retrofit (cfm25) & 283 & 259 & 195 & 191 \\
\hline Reduction (cfm25) & 330 & 375 & 302 & 320 \\
\hline Percent reduction & $52 \%$ & $52 \%$ & $55 \%$ & $56 \%$ \\
\hline
\end{tabular}

a "Supply" and "Return" indicate where the duct pressure probe was inserted in making the measurements. ${ }^{b}$ Measurements of duct leakage to the outside were made in basement houses with the basement isolated from the rest of the house and open to the outside in all cases, whether the basement might be considered conditioned or not. 
With the exception of a few "outliers," the duct leakages ascertained by measuring the duct pressures in the supply ducts were about the same as those when the duct pressures were measured in the return ducts (see Fig. 5.1). The outliers occurred when catastrophic leaks were present in either the supply or return duct. Catastrophic leaks made it impossible to pressurize the duct system to $25 \mathrm{~Pa}$. This required extrapolating measurements to $25 \mathrm{~Pa}$ and led to very unusual results. As seen in Fig. 5.1, fewer outliers occurred when the post-retrofit data are examined because the catastrophic leaks had been repaired. Similarly, the total duct leakages are highly correlated with the duct leakages to the outside (see Fig. 5.2). Consequently, later figures will show just results for total duct leakage based on supply pressure unless noteworthy differences are present for measurements of outside duct leakage or based on return pressure.

Pre-Retrofit Total Duct Leakage

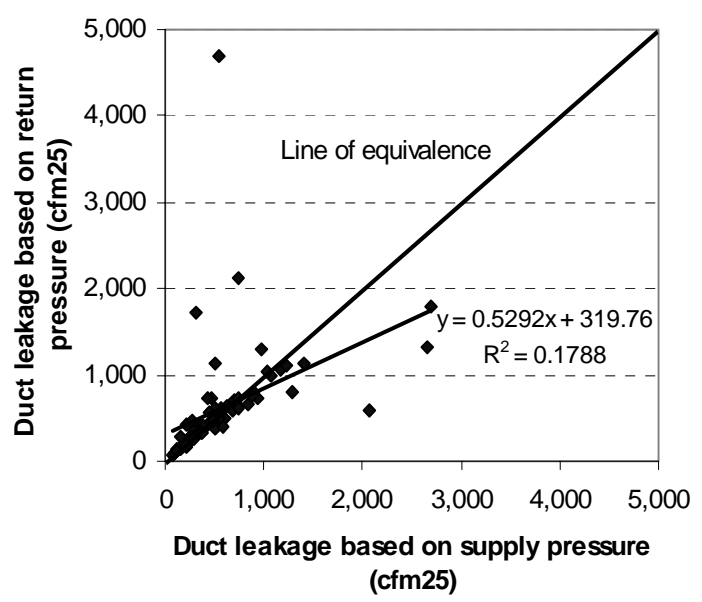

(a)

\section{Pre-Retrofit Duct Leakage to the Outside}

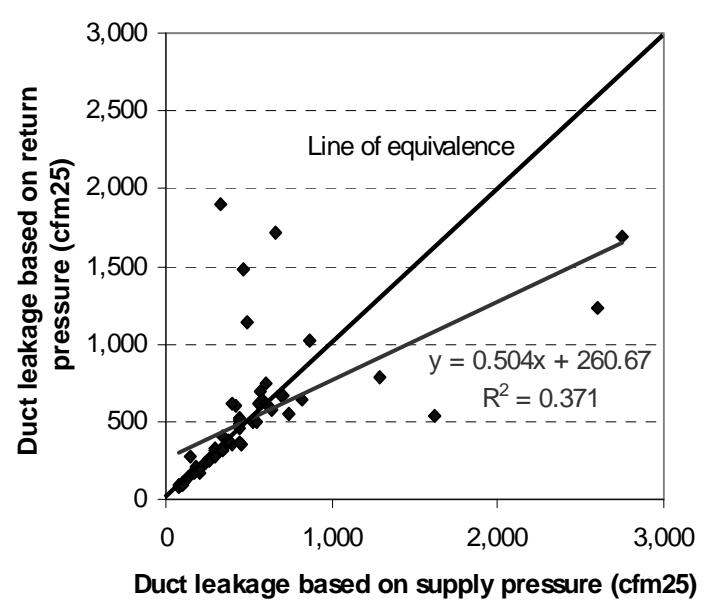

(c)

\section{Post-Retrofit Total Duct Leakage}

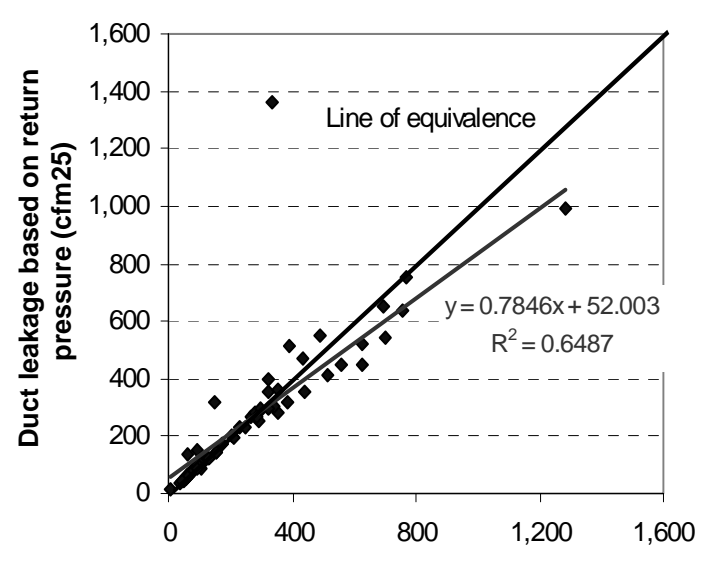

Duct leakage based on supply pressure (cfm25)

(b)

\section{Post-Retrofit Duct Leakage to the Outside}

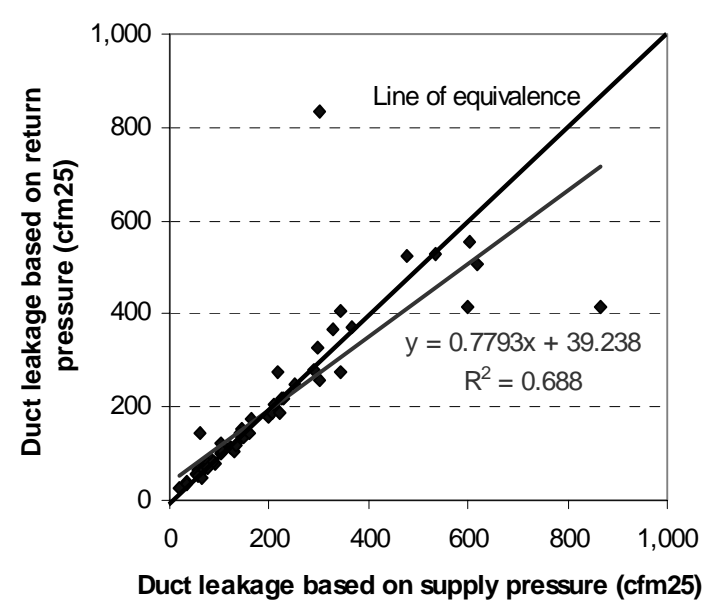

(d)

Fig. 5.1. Comparison of duct leakages measured by pressurizing the supply ducts to $25 \mathrm{~Pa}$ with those measured by pressurizing the return ducts to $25 \mathrm{~Pa}$. 


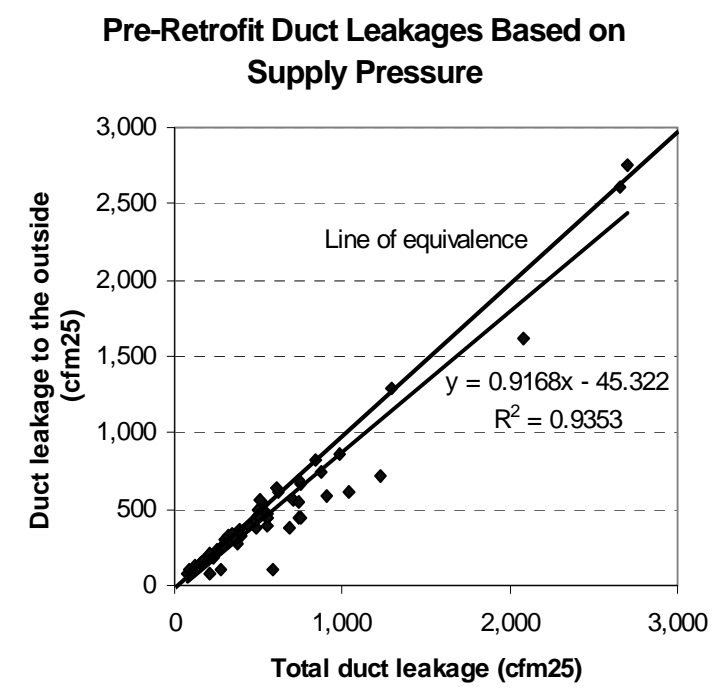

(a)

\section{Pre-Retrofit Duct Leakages Based on Return Pressure}

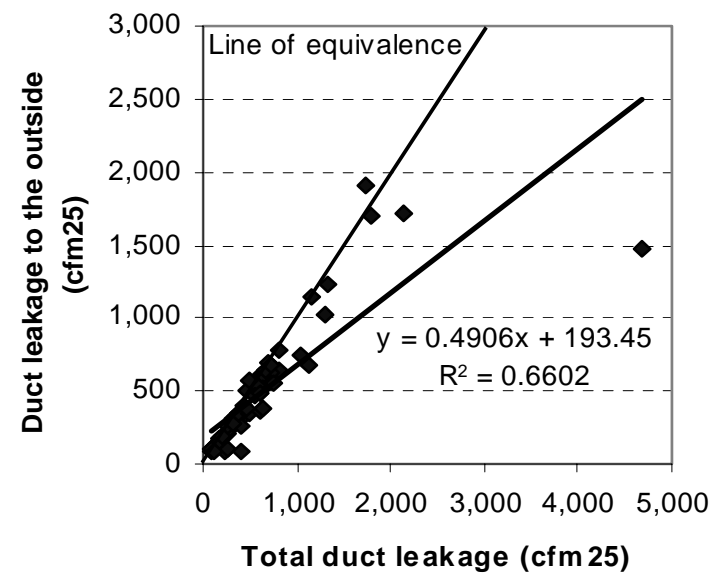

(c)

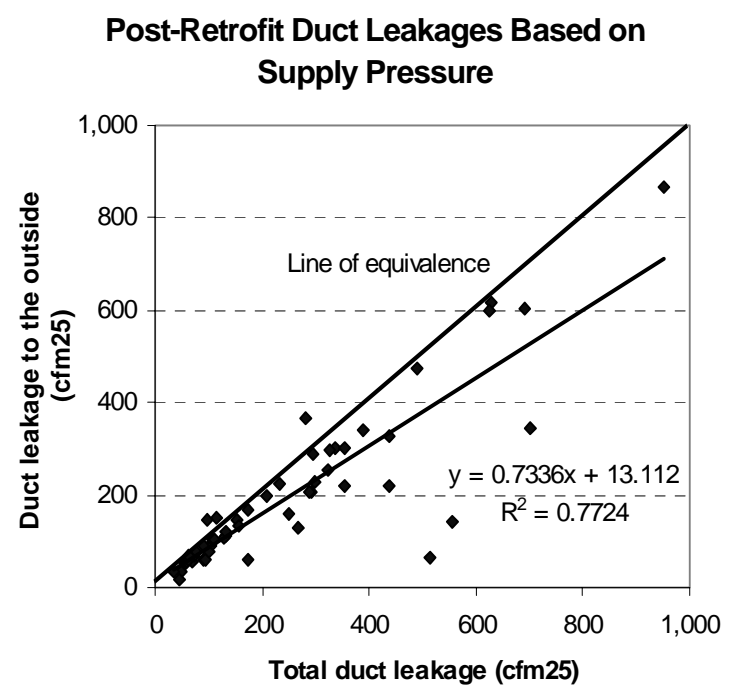

(b)

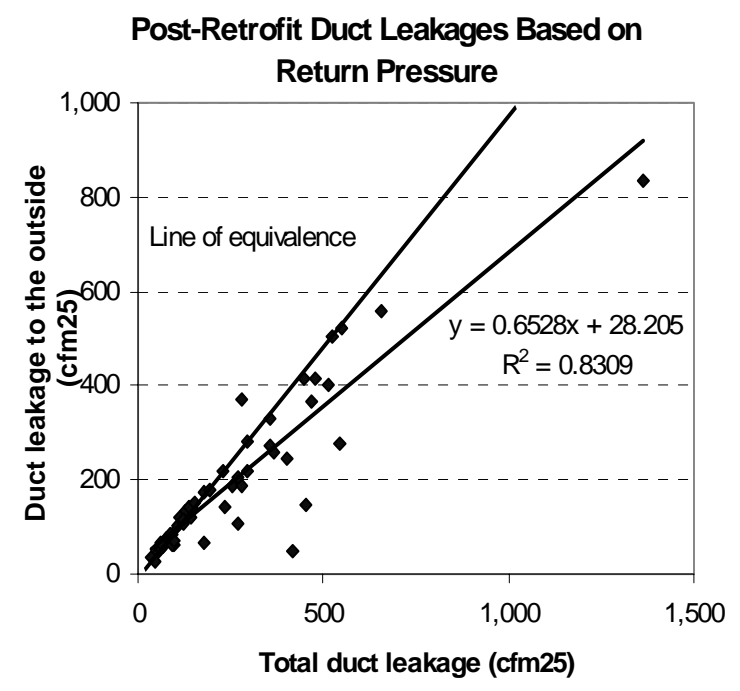

(d)

Fig. 5.2. Comparison of total duct leakages to duct leakages to the outside.

The impact of the duct-sealing work is shown graphically in Fig. 5.3. About $65 \%$ of the pre-retrofit duct leakages were $600 \mathrm{cfm} 25$ or less, but some values ranged as high as $2,400 \mathrm{cfm} 25$ or more. Catastrophic leaks as described above led to these large duct leakage measurements, which, at first glance, appear to be incorrect. The shift to lower duct leakage values following duct sealing is evident, with more than $50 \%$ of the houses having a duct leakage less than $200 \mathrm{cfm} 25$ and about $80 \%$ being below $400 \mathrm{cfm} 25$. However, this means that $20 \%$ of the houses were left with duct leakages greater than $400 \mathrm{cfm} 25$, with several houses being over $800 \mathrm{cfm} 25$. 


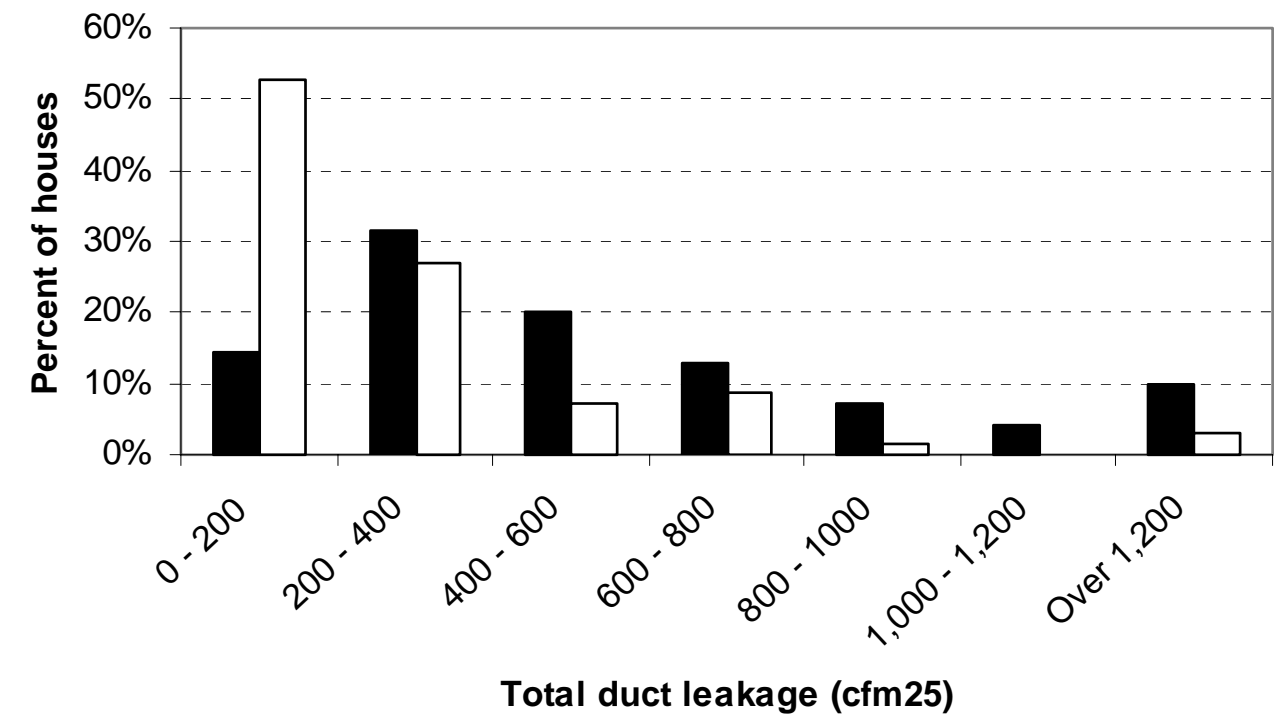

Before duct sealing $\square$ After duct sealing

Fig. 5.3. Distribution of total duct leakage based on pressurizing the supply ducts to $25 \mathrm{~Pa}$.

The distribution of duct leakage reductions and percentage reductions are shown in Figs. 5.4 and 5.5. About half of the duct leakage reductions were between 0 and $200 \mathrm{cfm} 25$, and large reductions (over $600 \mathrm{cfm} 25)$ were achieved in a little more than $10 \%$ of the homes. On a percentage basis, duct leakage reductions of $60 \%$ or more were achieved in about half the houses.

The pre-retrofit duct leakages measured in this field test (497-634 cfm25) are higher than the average duct leakage of 150-400 cfm25 often measured in other studies (Davis and Robinson 1993; Davis, Baylon, and Houseknecht 1998; Kallett et al. 2000; Kinert et al. 1992; Kolb and Ternes 1995; and Vigil 1993). These studies were usually performed in housing that was not low-income housing. The data from our study indicate that weatherization-eligible homes may have more duct leaks than the general population of U.S. homes and, thus, may be better candidates for duct sealing than these other studies might suggest.

The post-retrofit duct leakages found in our study are also much greater than new construction standards. A typical standard used by some states, utilities, and other agencies is that duct leakage in units of $\mathrm{cfm} 25$ should be no greater than $5 \%$ of conditioned floor area. For the average field test home, this would be about $65 \mathrm{cfm} 25$ - significantly lower than the average post-retrofit duct leakages achieved in this field test, which ranged from 191 to $283 \mathrm{cfm} 25$. Thus, opportunities for greater reductions may remain. 


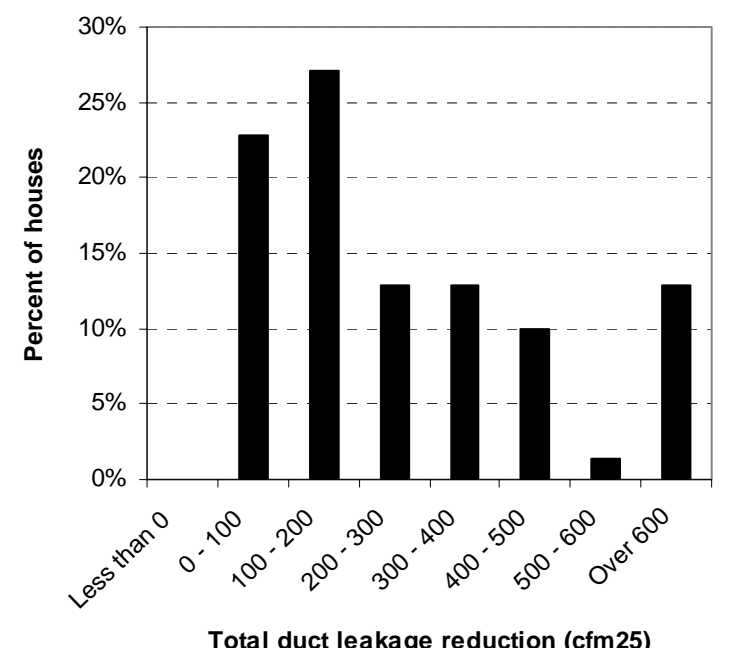

Fig. 5.4. Distribution of total duct-leakage reductions based on pressurizing the supply ducts to 25 Pa.

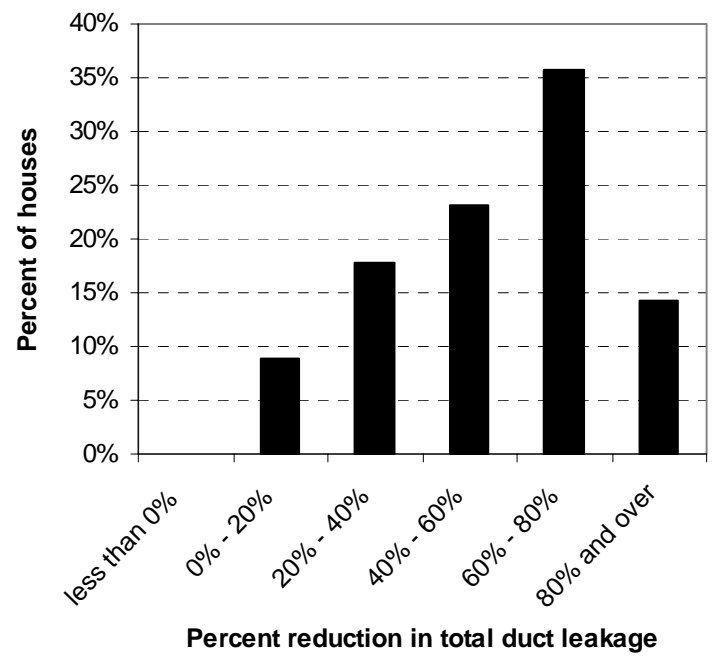

Fig. 5.5. Distribution of the percentage reductions in total duct leakage based on pressurizing the supply ducts to $25 \mathrm{~Pa}$.

\subsection{COMPARISON BETWEEN BEST-PRACTICE AND AEROSOL HOUSES}

Average duct leakages for houses sealed following the best-practice approach and those sealed with the aerosol-spray approach are provided in Table 5.2. The duct leakages measured when the return ducts were pressurized to $25 \mathrm{~Pa}$ will be discussed first.

Both the average pre-retrofit total duct leakages (642 and $626 \mathrm{cfm} 25)$ and duct leakages to the outside (534 and $489 \mathrm{cfm} 25$ ) of the two groups of houses are the same (not statistically different at 95 or even $90 \%$ confidence levels), indicating that the two groups of houses were equivalent before duct sealing occurred. After duct sealing, the average post-retrofit duct leakages of the aerosol-spray houses were about $50 \%$ less than those of the houses receiving just best-practice treatment (166 cfm 25 compared with $352 \mathrm{cfm} 25$ for the total duct leakage and $140 \mathrm{cfm} 25$ compared with $245 \mathrm{cfm} 25$ for the duct leakage to the outside), and the average percentage reductions were greater (67 and 63\% compared with 38 and 49\%). Both the average post-retrofit values and average percentage reductions are statistically different between groups at a $95 \%$ confidence level. Although the average reductions achieved by the aerosol homes were greater than those achieved in the bestpractice houses ( $460 \mathrm{cfm} 25$ and $349 \mathrm{cfm} 25$ compared with $289 \mathrm{cfm} 25$ for both cases), the scatter in the reductions for individual houses is so great that these average differences are not statistically different at a 95 or $90 \%$ confidence level. Taken as a whole, though, these data clearly indicate that the aerosol-spray technology was more effective at sealing duct leaks than use of best-practice approaches alone.

Examination of the duct leakages measured when the supply ducts were pressurized to $25 \mathrm{~Pa}$ indicates that the two groups of houses were not equivalent before duct sealing. The average preretrofit duct leakages of the best-practice houses were twice those for the aerosol homes $(862 \mathrm{cfm} 25$ compared with $364 \mathrm{cfm} 25$ for the total duct leakage and $692 \mathrm{cfm} 25$ compared with $309 \mathrm{cfm} 25$ for the 
Table 5.2. Average duct leakage results for best-practice and aerosol-sealed houses

\begin{tabular}{|l|c|c|c|c|c|c|c|c|}
\hline \multirow{2}{*}{ Parameter } & \multicolumn{4}{c|}{ Total duct leakage $^{a}$} & \multicolumn{3}{c|}{ Duct leakage to the outside $^{a, b}$} \\
\cline { 2 - 10 } & \multicolumn{2}{|c|}{ Supply } & \multicolumn{2}{c|}{ Return } & \multicolumn{2}{c|}{ Supply } & \multicolumn{2}{c|}{ Return } \\
\cline { 2 - 10 } & $\begin{array}{c}\text { Best- } \\
\text { practice }\end{array}$ & Aerosol & $\begin{array}{c}\text { Best- } \\
\text { practice }\end{array}$ & Aerosol & $\begin{array}{c}\text { Best- } \\
\text { practice }\end{array}$ & Aerosol & $\begin{array}{c}\text { Best- } \\
\text { practice }\end{array}$ & Aerosol \\
\hline \hline Number of houses & 35 & 35 & 34 & 34 & 28 & 29 & 28 & 29 \\
\hline Pre-retrofit (cfm25) & 862 & 364 & 642 & 626 & 692 & 309 & 534 & 489 \\
\hline Post-retrofit (cfm25) & 444 & 122 & 352 & 166 & 279 & 115 & 245 & 140 \\
\hline Reduction (cfm25) & 418 & 242 & 289 & 460 & 413 & 195 & 289 & 349 \\
\hline Percent reduction & $41 \%$ & $63 \%$ & $38 \%$ & $67 \%$ & $50 \%$ & $60 \%$ & $49 \%$ & $63 \%$ \\
\hline
\end{tabular}

a "Supply" and "Return" indicate where the duct pressure probe was inserted in making the measurements.

${ }^{b}$ Measurements of duct leakage to the outside were made in basement houses with the basement isolated from the rest of the house and open to the outside in all cases, whether the basement might be considered conditioned or not.

duct leakage to the outside), and these differences were statistically significant at the $95 \%$ confidence level. The pressure pan measurements discussed in Sect. 6 also indicate that the two groups of houses may not have been truly equivalent. Because any performance difference between methods could be due to houses' being leakier or tighter before duct sealing, no inferences concerning performance can be drawn from these data. Moreover, these data as well as the pressure pan measurements call into question the equivalency of the two groups of houses, and thus, the conclusions reached when just the return measurements were examined.

The dependancy of duct leakage reduction on pre-retrofit duct leakage values was examined to factor out the possible inequality of initial duct leakages between the two groups of houses (see Fig. 5.6). For the measurements based on the supply pressure, the reason that the average pre-retrofit duct leakages of the best-practice group are so much larger than the averages for the aerosol group is clearly shown in Fig. 5.6 (a) and (c): the best-practice group has eight houses with higher pre-retrofit total duct leakages than any of those in the aerosol group and nine houses with higher pre-retrofit outside duct leakages. Likewise, the more even distribution of pre-retrofit duct leakages between groups when measurements are based on return pressure is evident (although the aerosol group has one house with a much higher total pre-retrofit duct leakage than the rest of the houses), which is why the averages of the two groups are about the same.

Figure 5.6 presents a simple linear regression model for each group of houses in the four plots. Because the coefficient of determinations $\left(\mathrm{R}^{2}\right)$ of these models are all greater than 0.7 , the models are reasonable representations of how duct leakage reduction varies depending on the initial duct leakage. Assuming houses with initial duct leakages of 300 and $600 \mathrm{cfm} 25$, Table 5.3 provides reductions estimated by the models. 


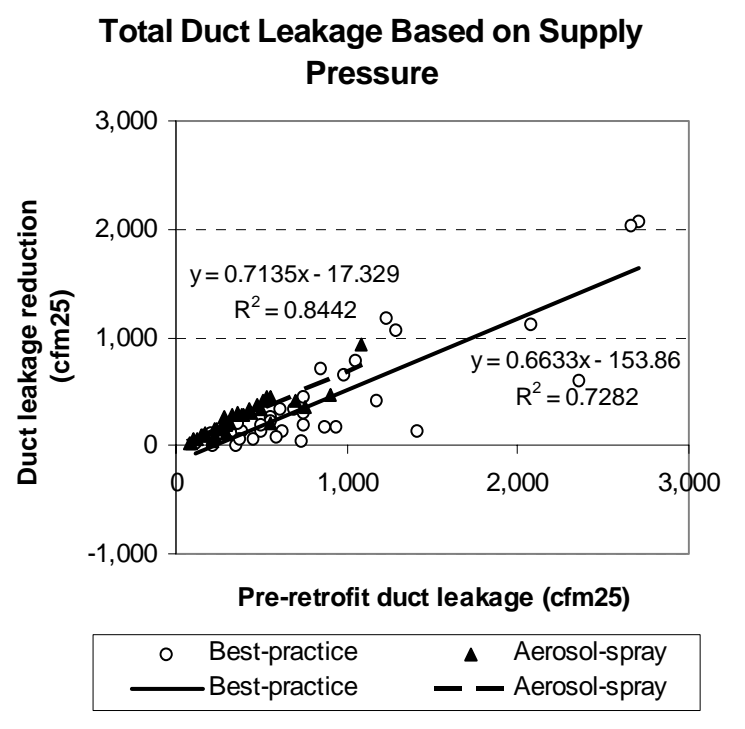

(a)

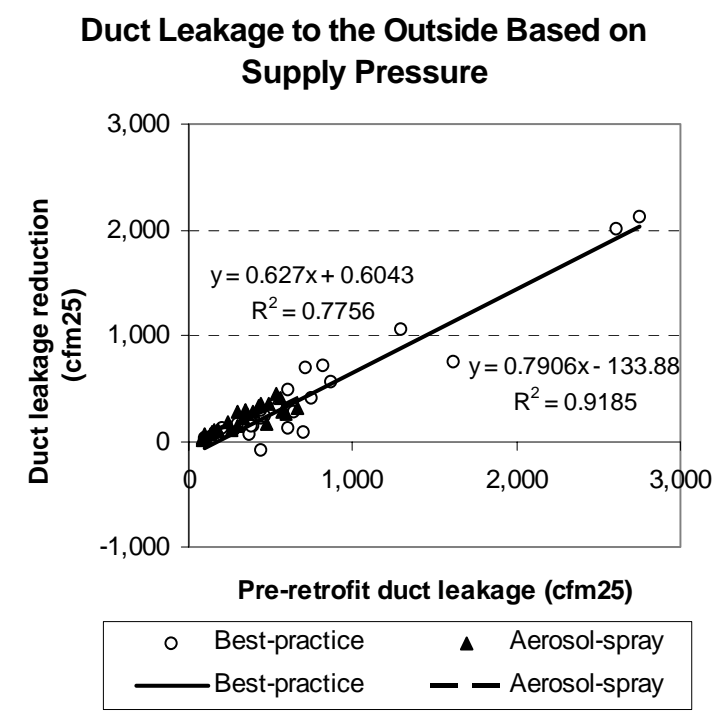

(c)

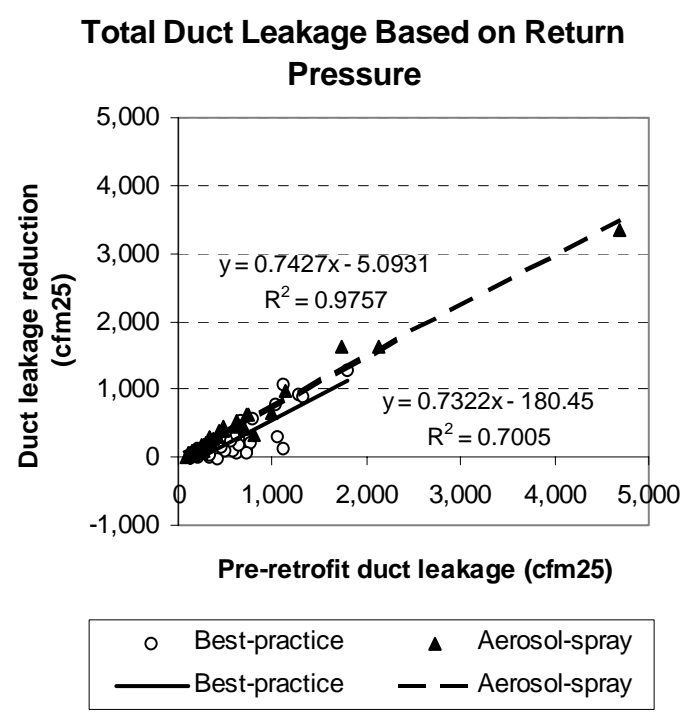

(b)

\section{Duct Leakage to the Outside Based on Return Pressure}

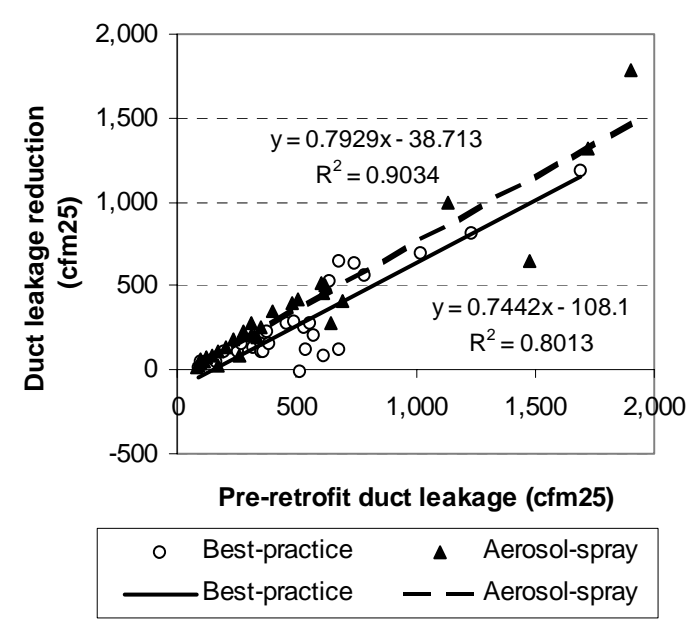

(d)

Fig. 5.6. Comparison of duct leakage reductions to pre-retrofit duct leakages using all the houses with available data.

In three of the four cases, the models predict that greater reductions in duct leakage would be achieved in a house sealed with the aerosol-spray technology than with the best-practice approach regardless of the initial duct leakage. This difference is about $160 \mathrm{cfm} 25$ when total duct leakage based on supply pressure is considered, and about $180 \mathrm{cfm} 25$ and $90 \mathrm{cfm} 25$ when total and outside duct leakage based on return pressures are considered. These differences are fairly constant for a wide range of initial duct leakages because the slopes of the models are about the same for each measurement considered. In the fourth case — outside duct leakage based on supply pressure - the models predict greater reductions in duct leakage from use of the aerosol-spray technology if the initial duct leakage is less than about $800 \mathrm{cfm} 25$ and greater reductions in duct leakage for the best- 
Table 5.3. Comparison of predicted duct leakage reductions

\begin{tabular}{|l|c|c|c|c|c|c|c|c|}
\hline & \multicolumn{4}{|c|}{300 cfm25 } & \multicolumn{4}{c|}{ 600 cfm25 } \\
\cline { 2 - 10 } $\begin{array}{l}\text { Duct leakage } \\
\text { measurement }\end{array}$ & $\begin{array}{c}\text { Aerosol } \\
\text { (cfm25) }\end{array}$ & $\begin{array}{c}\text { Best- } \\
\text { practice } \\
\text { (cfm25) }\end{array}$ & $\begin{array}{c}\text { Difference } \\
\text { (cfm25) }\end{array}$ & Ratio & $\begin{array}{l}\text { Aerosol } \\
\text { (cfm25) }\end{array}$ & $\begin{array}{c}\text { Best- } \\
\text { practice } \\
\text { (cfm25) }\end{array}$ & $\begin{array}{c}\text { Difference } \\
\text { (cfm25) }\end{array}$ & Ratio \\
\hline \hline Total supply & 197 & 45 & 152 & 4.38 & 411 & 244 & 167 & 1.68 \\
\hline Total return & 218 & 39 & 179 & 5.59 & 441 & 259 & 182 & 1.70 \\
\hline Outside supply & 189 & 103 & 86 & 1.84 & 377 & 340 & 37 & 1.11 \\
\hline Outside return & 199 & 115 & 84 & 1.73 & 437 & 338 & 99 & 1.29 \\
\hline
\end{tabular}

practice approach above this value. However, this requires extrapolating the model for the aerosol group beyond the range of data used to create the model, which can lead to incorrect conclusions.

The pre-retrofit duct leakages at which the predicted reductions in duct leakage are zero are tabulated in Table 5.4. In houses with initial duct leakages below these values, no reduction in duct leakage would be expected from ductsealing work. The values for the aerosol group are all less than $50 \mathrm{cfm} 25$ and, in all cases, are less than the values for the best-practice group, which range from about 150 to $250 \mathrm{cfm} 25$. Thus, these field test results indicate that the aerosol-spray technology is able to seal houses with moderate duct leakage, whereas use only of best-practice approaches would have little impact on these houses.

In three of the four cases, the $\mathrm{R}^{2}$ of the model for the aerosol group of houses is larger than the value for the model of the best-practice houses. This indicates that the aerosol-spray technology was able to produce a more consistent reduction in duct leakage than the best-practice approach.

As previously discussed, with the exception of the models developed for outside duct leakage based on return pressure, the models presented in Fig. 5.6 (and hence the model results presented in Tables 5.3 and 5.4) were developed using aerosol-spray-treated houses that had a different range of pre-retrofit duct leakages than the best-practice houses. An investigation was performed to determine whether the models were overly influenced by duct leakage reductions obtained in houses with high initial duct leakages. In order to create groups of houses with more comparable ranges of pre-retrofit duct leakages, we eliminated houses before redeveloping the models. Eight best-practice houses were dropped in analyzing the total duct leakage based on the supply duct pressure, one aerosol house was eliminated from analysis of the total duct leakage based on the return duct pressure, and four houses were dropped in analyzing the outside duct leakage based on the supply duct pressure. No houses were dropped in reanalyzing the outside duct leakage based on the return duct pressure because the range of pre-retrofit duct leakages was already about the same for the aerosol and bestpractice groups. 
Models using this subset of houses are presented in Fig. 5.7, and results are presented in Tables 5.5 and 5.6. Overall, the results based on the subset of houses are about the same as those obtained for the full set of houses (keeping in mind the different scales in comparing Figs. 5.6 and 5.7). Within the range of pre-retrofit duct leakages used to develop the models, the models in all four cases predict better performance from use of the aerosol-spray technology than use of best-practice approaches alone. In three cases, the differences are more pronounced as the initial duct leakage increases. The pre-retrofit duct leakages below which the predicted duct leakages are zero are again less for the aerosol group, indicating that more houses could benefit from duct sealing if the aerosol-spray technology were used. The $\mathrm{R}^{2}$ of the two new models for the best-practice houses decreased

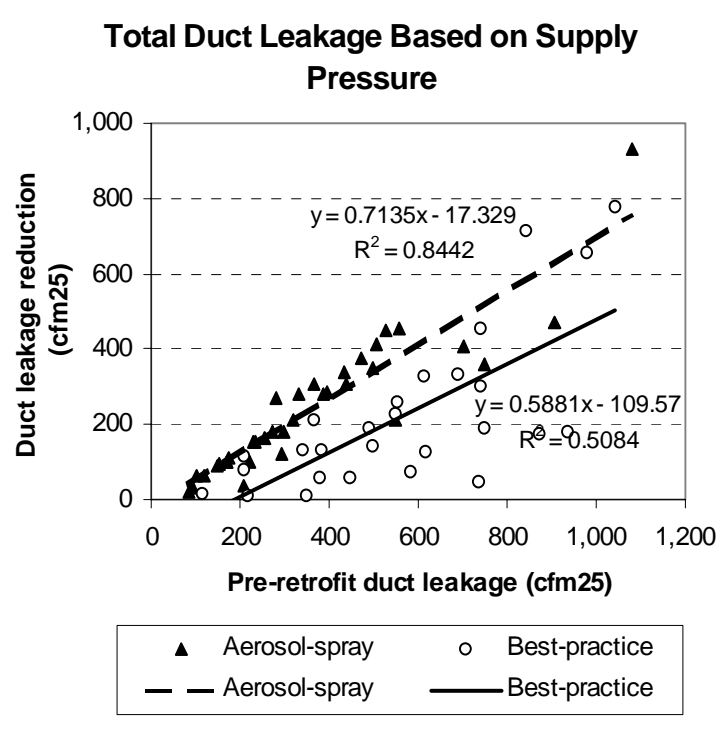

(a)

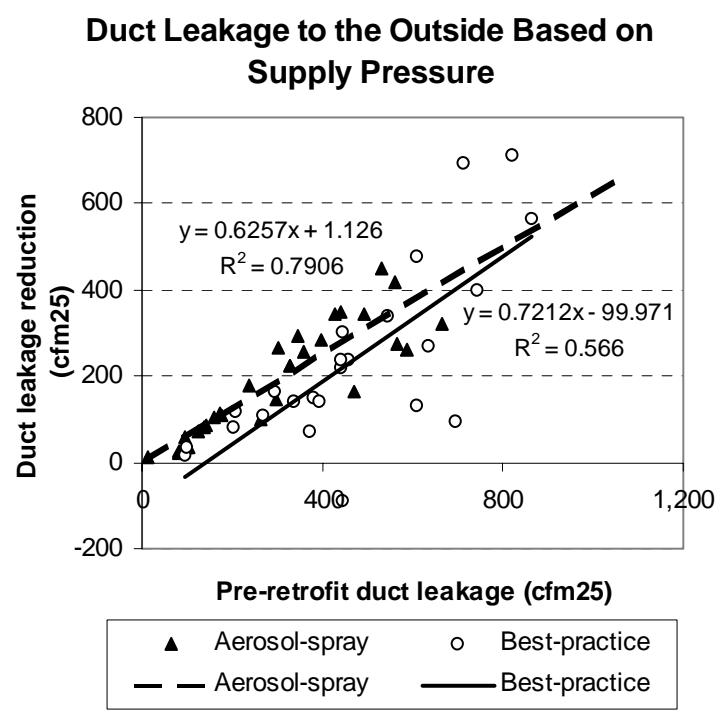

(c)

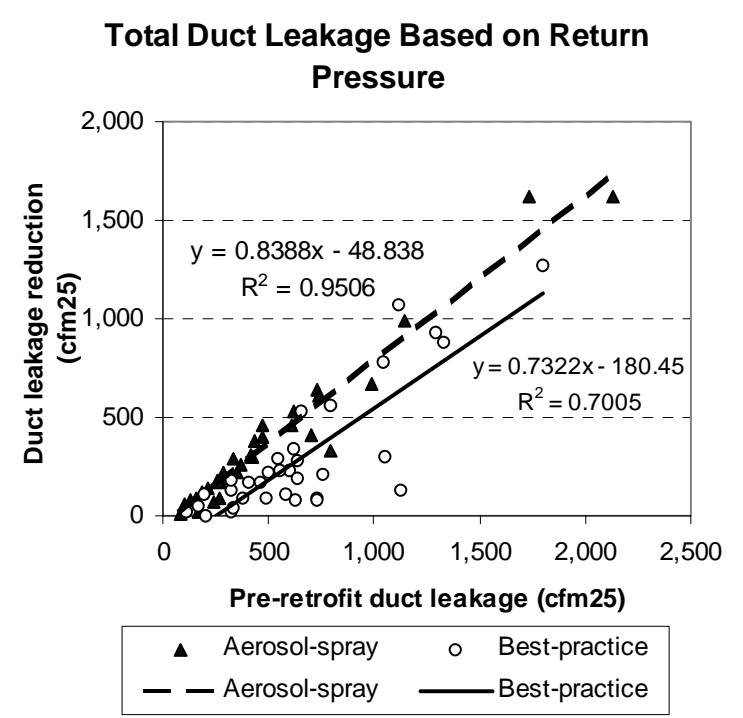

(b)

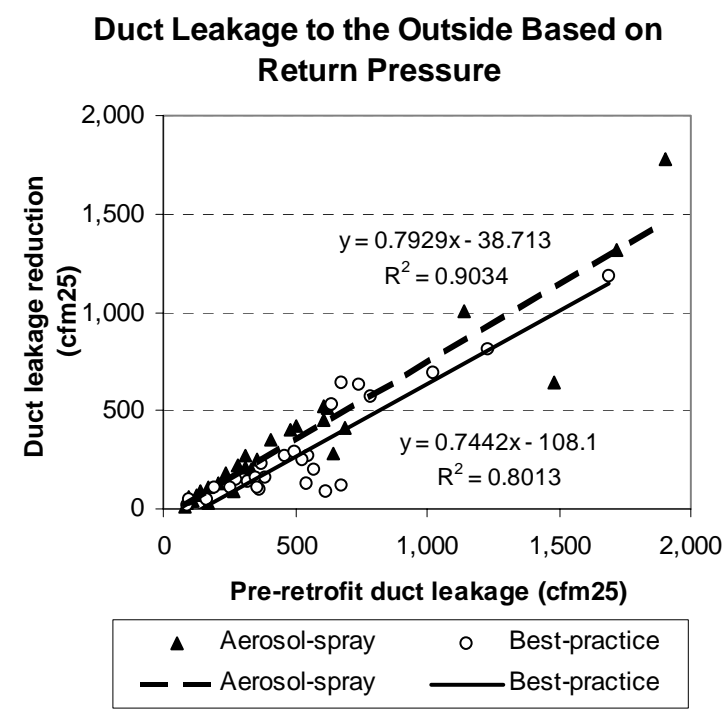

(d)

Fig. 5.7. Comparison of duct-leakage reductions to pre-retrofit duct leakages using a subset of aerosol-spray-treated and best-practice-treated houses with the same relative range of duct leakages. 
Table 5.5. Comparison of predicted duct-leakage reductions for the subset of comparable houses

\begin{tabular}{|l|c|c|c|c|c|c|c|c|}
\hline & \multicolumn{4}{|c|}{300 cfm25 } & \multicolumn{4}{c|}{600 cfm25 } \\
\cline { 2 - 9 } $\begin{array}{c}\text { Duct leakage } \\
\text { measurement }\end{array}$ & $\begin{array}{c}\text { Aerosol } \\
\text { (cfm25) }\end{array}$ & $\begin{array}{c}\text { Best- } \\
\text { practice } \\
\text { (cfm25) }\end{array}$ & $\begin{array}{c}\text { Difference } \\
\text { (cfm25) }\end{array}$ & Ratio & $\begin{array}{l}\text { Aerosol } \\
\text { (cfm25) }\end{array}$ & $\begin{array}{c}\text { Best- } \\
\text { practice } \\
\text { (cfm25) }\end{array}$ & $\begin{array}{c}\text { Difference } \\
\text { (cfm25) }\end{array}$ & Ratio \\
\hline \hline Total supply & 197 & 67 & 130 & 2.94 & 411 & 243 & 168 & 1.69 \\
\hline Total return & 203 & 39 & 164 & 5.21 & 454 & 259 & 195 & 1.75 \\
\hline Outside supply & 189 & 116 & 73 & 1.63 & 377 & 333 & 44 & 1.13 \\
\hline Outside return & 199 & 115 & 84 & 1.73 & 437 & 338 & 99 & 1.29 \\
\hline
\end{tabular}

Table 5.6. Intercepts of regression models along the horizontal axis (cfm25) for the subset of comparable houses

\begin{tabular}{|l|c|c|}
\hline $\begin{array}{c}\text { Duct leakage } \\
\text { measurement }\end{array}$ & $\begin{array}{c}\text { Aerosol-spray } \\
\text { technology }\end{array}$ & $\begin{array}{c}\text { Best-practice } \\
\text { technology }\end{array}$ \\
\hline \hline Total supply & 24 & 186 \\
\hline Total return & 58 & 246 \\
\hline Outside supply & -2 & 139 \\
\hline Outside return & 49 & 145 \\
\hline
\end{tabular}

considerably (from 0.7282 to 0.5084 and from 0.9185 to 0.566 ), while the $\mathrm{R}^{2}$ of the new model for the aerosol houses decreased only slightly (from 0.9757 to 0.9506 ). In this subset, all the $\mathrm{R}^{2}$ values of the models for the aerosol group of houses are larger than the values for the best-practice models, further reinforcing the evidence that crews can achieve more consistent results with the aerosol-spray technology.

By applying the models developed using all the houses (setting reductions to zero if the models predicted negative reductions), we estimated duct leakage reductions for each house in the field test as if it had first been treated conventionally and then by the aerosol-spray technology. The average values for this simulated group presented in Table 5.7 are the best indicators of how the aerosolspray and best-practice approaches compare on average. Average reductions in duct leakage that would be expected from this simulated aerosol group are higher than those for the best-practice group by 44-170 cfm 25, a 16-60\% improvement depending on the measurement type being considered. Percentage reductions achieved by the aerosol group are also higher (63-74\% compared with $43-54 \%$ for the best-practice group).

The estimated reductions in duct leakage from using the best-practice approach (263-296 cfm25) and the aerosol-spray approach $(312-466 \mathrm{cfm} 25)$ in this field test are both greater than the $75-171 \mathrm{cfm} 25$ reductions reported in other studies using conventional approaches (Cummings et al. 1990; Davis and Robinson 1993; Davis, Baylon, and Houseknecht 1998; Kinert et al. 1992; and Kolb and Ternes 1995). 
Table 5.7. Average duct leakage results for simulated set of best-practice and aerosol-sealed houses

\begin{tabular}{|c|c|c|c|c|c|c|c|c|}
\hline \multirow[b]{3}{*}{ Parameter } & \multicolumn{4}{|c|}{ Total duct leakage ${ }^{a}$} & \multicolumn{4}{|c|}{ Duct leakage to the outside ${ }^{a, b}$} \\
\hline & \multicolumn{2}{|c|}{ Supply } & \multicolumn{2}{|c|}{ Return } & \multicolumn{2}{|c|}{ Supply } & \multicolumn{2}{|c|}{ Return } \\
\hline & $\begin{array}{c}\text { Best- } \\
\text { practice }\end{array}$ & Aerosol & $\begin{array}{c}\text { Best- } \\
\text { practice }\end{array}$ & Aerosol & $\begin{array}{c}\text { Best- } \\
\text { practice }\end{array}$ & Aerosol & $\begin{array}{c}\text { Best- } \\
\text { practice }\end{array}$ & Aerosol \\
\hline Number of houses & 70 & 70 & 68 & 68 & 57 & 57 & 57 & 57 \\
\hline Pre-retrofit (cfm25) & 613 & 613 & 634 & 634 & 497 & 497 & 511 & 511 \\
\hline Post-retrofit (cfm25) & 350 & 193 & 338 & 168 & 229 & 185 & 234 & 144 \\
\hline Reduction (cfm25) & 263 & 420 & 296 & 466 & 268 & 312 & 277 & 367 \\
\hline Percent reduction & $43 \%$ & $68 \%$ & $47 \%$ & $74 \%$ & $54 \%$ & $63 \%$ & $54 \%$ & $72 \%$ \\
\hline
\end{tabular}

a "Supply" and "Return" indicate where the duct pressure probe was inserted in making the measurements.

${ }^{b}$ Measurements of duct leakage to the outside were made in basement houses with the basement isolated from the rest of the house and open to the outside in all cases, whether the basement might be considered conditioned or not.

The percentage reductions for the best-practice approach (43-54\%) are consistent with the reported percentage reductions of 30-74\% for these other studies. The percentage reductions for the aerosolspray technology (63-74\%) are in the upper end of this range and consistent with a 78\% reduction obtained from another study of the aerosol-spray approach applied to non-low-income homes in Florida (Modera et al. 1996) and an $81 \%$ reduction found in a utility-based program in California (Kallett et al. 2000).

\subsection{COMPARISON BETWEEN AGENCIES}

Average pre- and post-retrofit duct leakages for each of the five agencies participating in the field test are shown in Fig. 5.8. Best-practice houses are grouped together with houses treated by the aerosol-spray technology in these graphs. The average duct leakages both before and after retrofit are fairly consistent among agencies. This points to a uniform rather than isolated problem with leaky ducts in weatherization-eligible homes in different regions of the country and indicates a similar quality of repair work among agencies. Initial duct leakages generally ranged from 400 to $600 \mathrm{cfm} 25$, with the primary exception being Agency D, where the average leakages were consistently higher (600-800 cfm25). The post-retrofit duct leakages (the level to which ducts could be tightened) were about $200 \mathrm{cfm} 25$, but only $400 \mathrm{cfm} 25$ in two cases for Agency E.

Average reductions in duct leakage were generally $200-300 \mathrm{cfm} 25$, with the notable exception being Agency D, where reductions of 400-600 cfm 25 were achieved, in part because the initial leakages were higher than for the other agencies. The average percentage reductions were usually between 40 and 60\%, as seen in Fig. 5.9.

For the total duct leakage based on supply pressure, the relation between reduction in duct leakage and initial duct leakage for each agency is shown separately in Fig. 5.10 for the conventional and aerosol houses. Similar results are obtained if outside duct leakage or measurements based on return pressure are considered. The coefficient of determination $\left(\mathrm{R}^{2}\right)$ values of the models for the best- 
Agency A

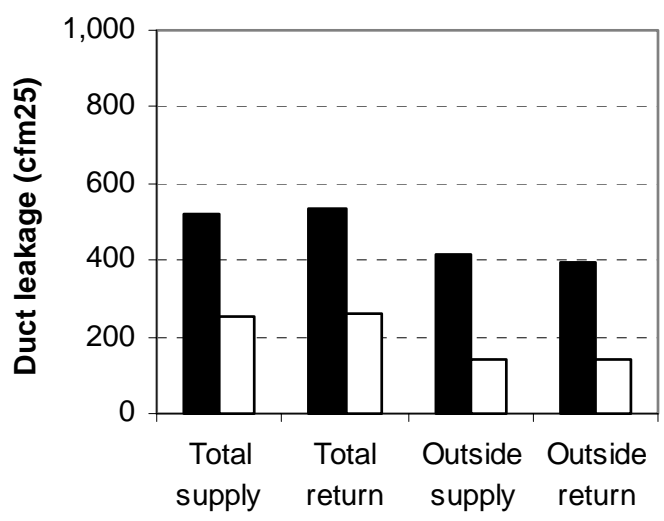

- Before duct sealing $\square$ After duct sealing

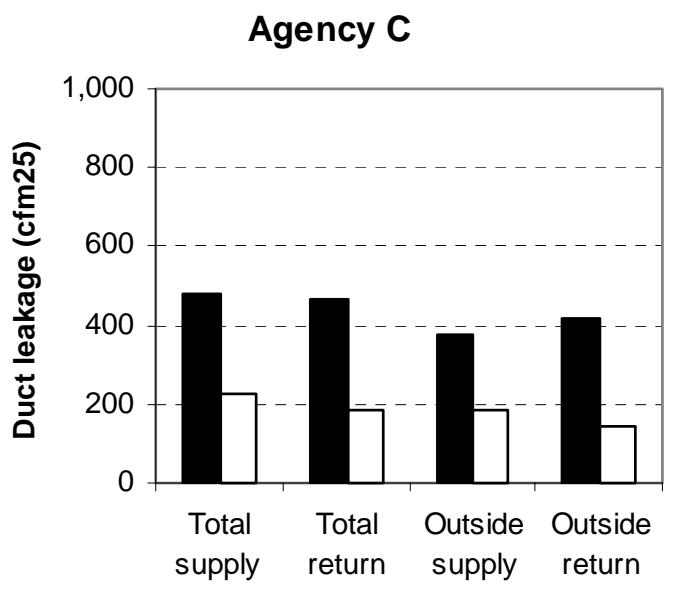

ש Before duct sealing $\quad \square$ After duct sealing

Agency E

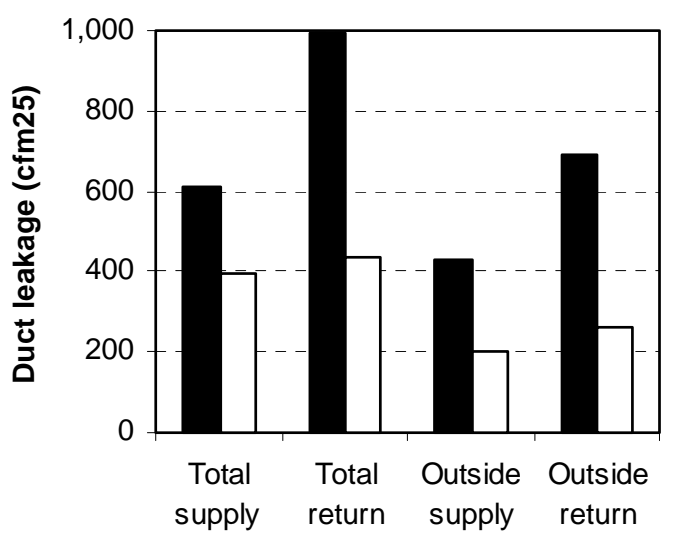

Before duct sealing $\quad \square$ After duct sealing

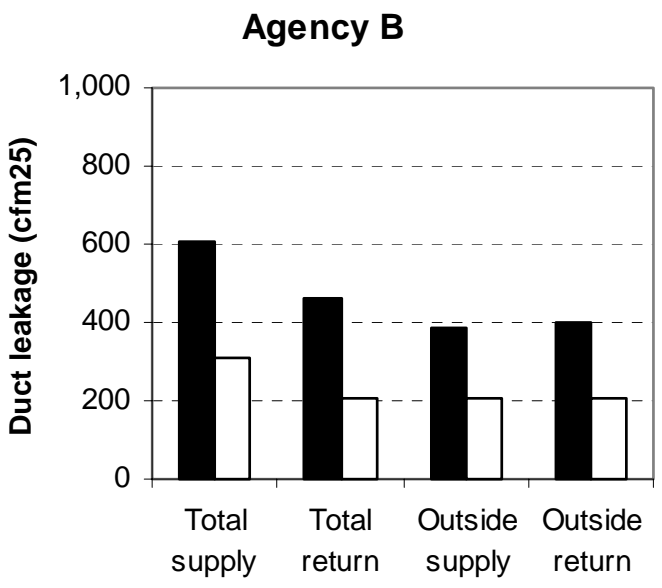

Before duct sealing $\square$ After duct sealing

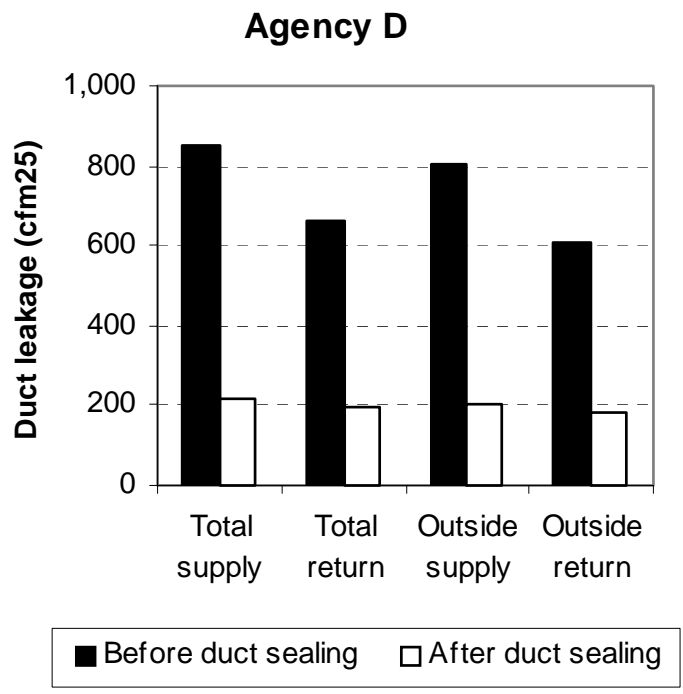

Fig. 5.8. Average pre- and post-retrofit duct leakages for each of the five weatherization agencies participating in the field test. 


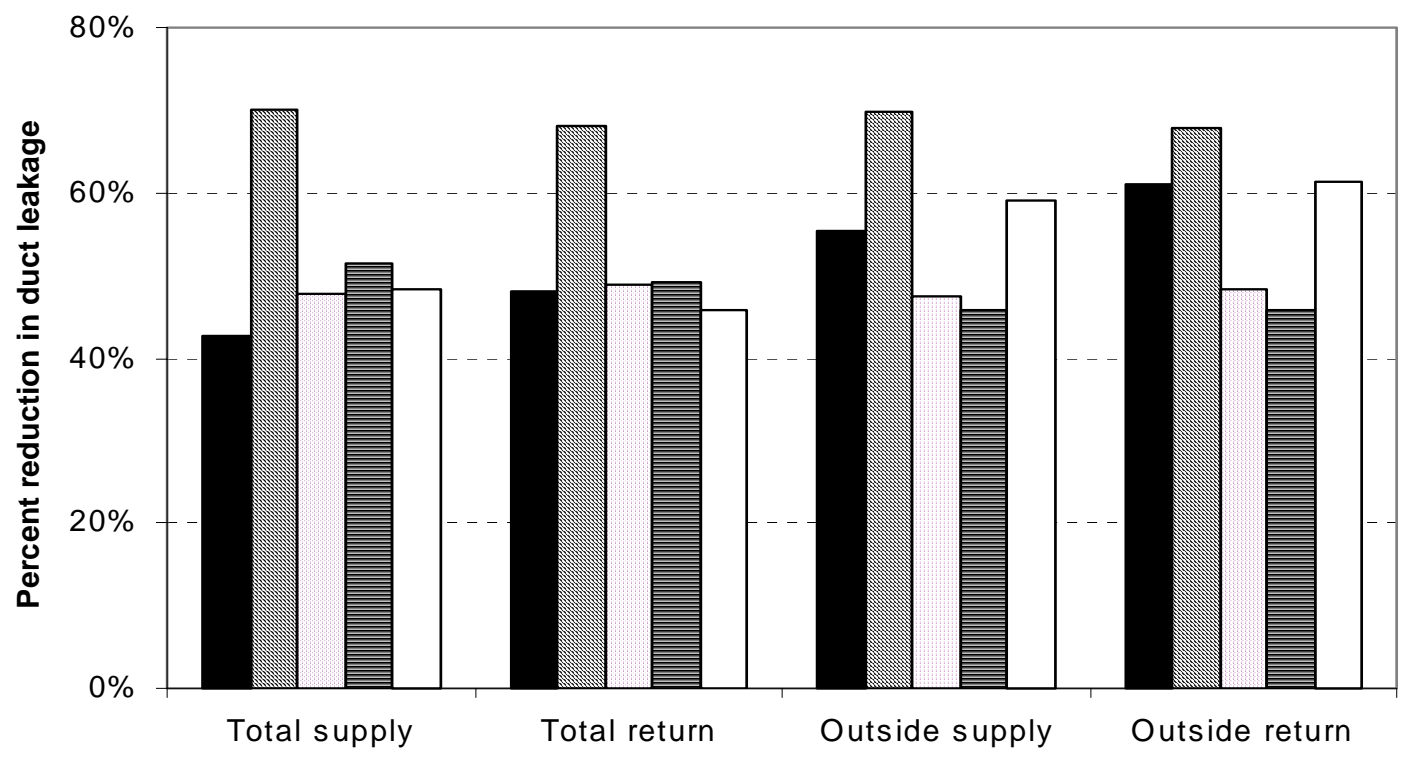

Agency E $\quad \square$ Agency D $\square$ Agency C 目Agency B $\square$ Agency A

Fig. 5.9. Average percentage reductions in duct leakage for each of the five weatherization agencies participating in the field test.

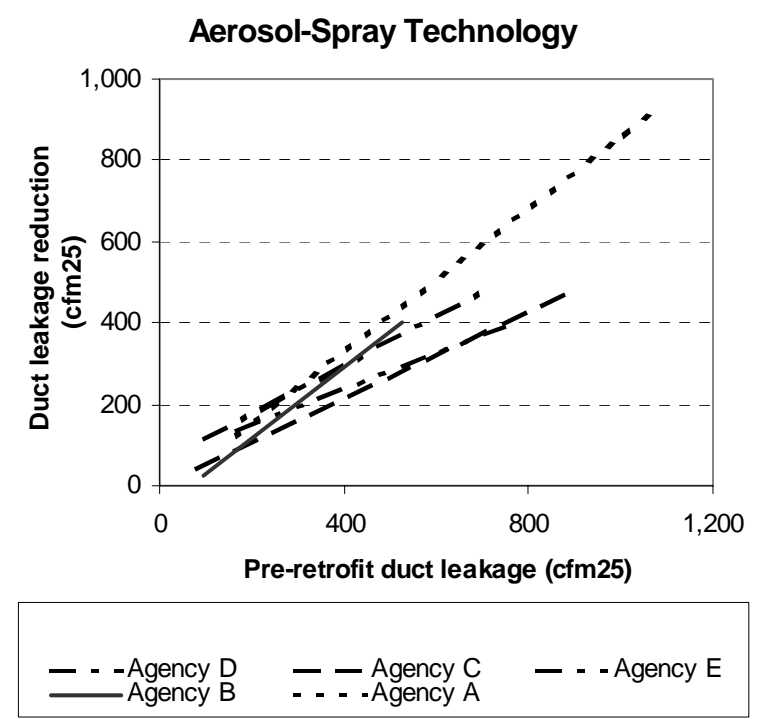

(a)

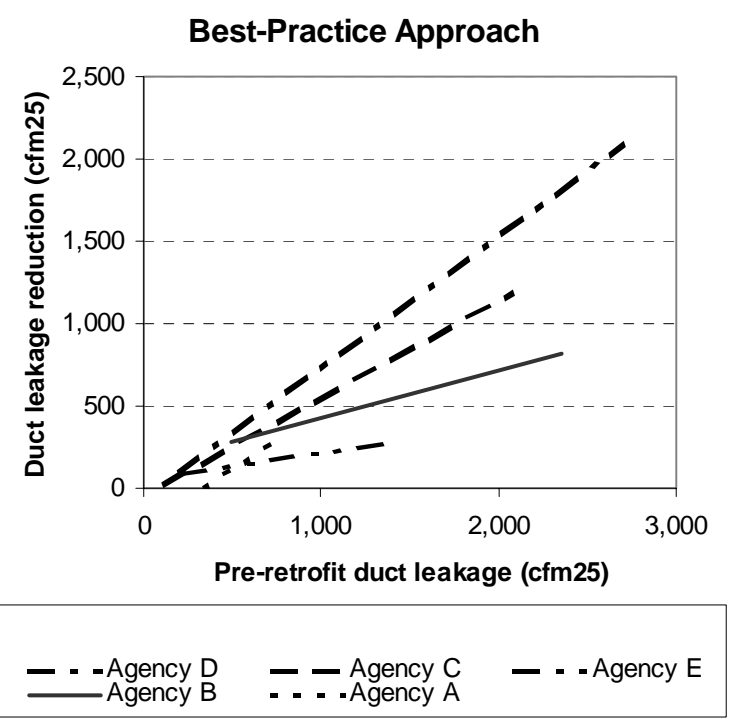

(b)

Fig. 5.10. Comparison of total duct leakage reductions (based on supply pressure) achieved by each weatherization agency, as a function of pre-retrofit total duct leakage using the aerosol-spray and best-practice technologies. 
practice houses are less than those for the aerosol houses as shown in Table 5.8. The lowest $\mathrm{R}^{2}$ value for the aerosol models is 0.68; values for three models of best-practice homes are less than this, with two being about 0.26 . This indicates that, within a given agency, the impacts of best-practice duct sealing are less consistent and predictable than when the aerosol technology is used. The models in Fig. 5.10 for the aerosol homes are closely grouped, whereas those for the best-practice houses are spread out. This indicates that consistent performance results are achieved by agencies using the aerosol-spray technology despite variations in variables such as house type and duct location, but performance results can vary more widely among agencies when best-practice approaches alone are used, possibly because of these same variations in house types and duct locations.

Although the number of houses in the best-practice and aerosol groups at each agency is too small to perform any rigorous analysis, comparison of the best-practice and aerosol models for each agency (Fig. 5.11) is enlightening. Performance using the aerosol-spray technology is clearly better than that obtained from using just best-practice methods at Agencies $\mathrm{A}$ and $\mathrm{E}$ and almost identical at Agencies C and D. The trend is not as clear for Agency B, although the aerosol approach probably outperforms the best-practice approach there as well. This comparison implies that the results obtained from the best-practice approach can equal those obtained with the aerosol approach in some cases. Whether this is due to agency skills or house characteristics is not known.

Table 5.8. Coefficient of determination $\left(\mathbf{R}^{2}\right)$ values for the models shown in Fig. 5.10

\begin{tabular}{|c|c|c|}
\hline Agency & Best-practice technology & Aerosol-spray technology \\
\hline \hline A & 0.63 & 0.99 \\
\hline B & 0.26 & 0.93 \\
\hline C & 0.94 & 0.93 \\
\hline D & 0.99 & 0.85 \\
\hline E & 0.26 & 0.68 \\
\hline
\end{tabular}




\section{Agency A}
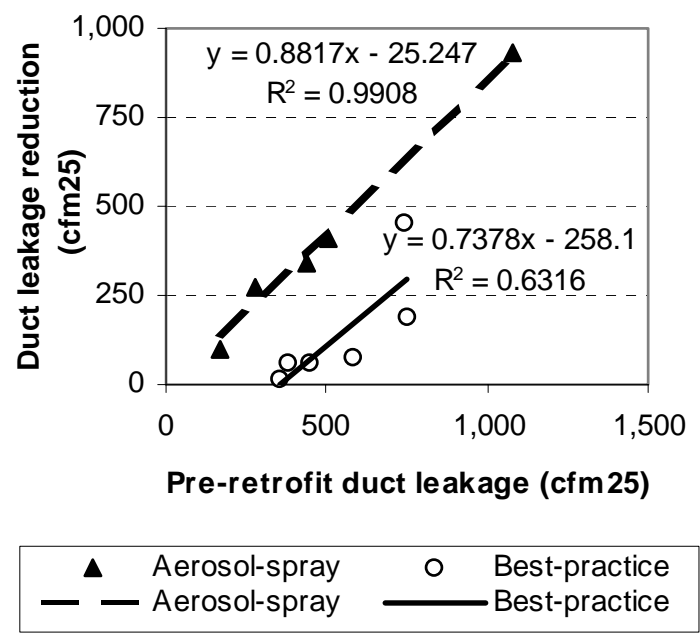

\section{Agency C}

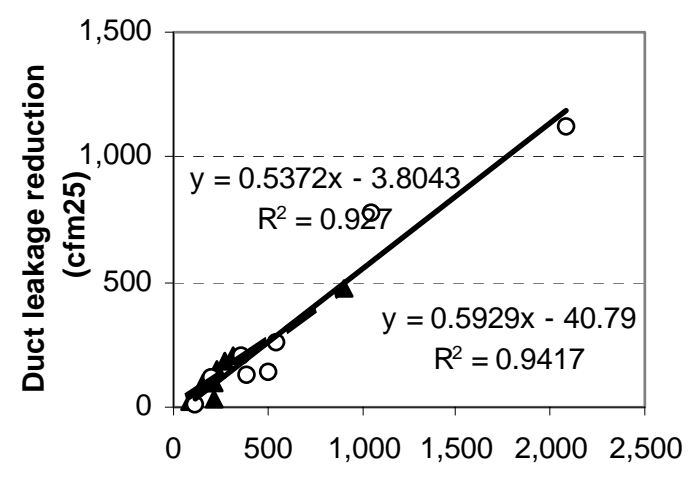

Pre-retrofit duct leakage (cfm 25)

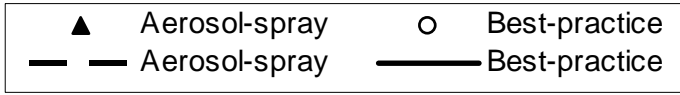

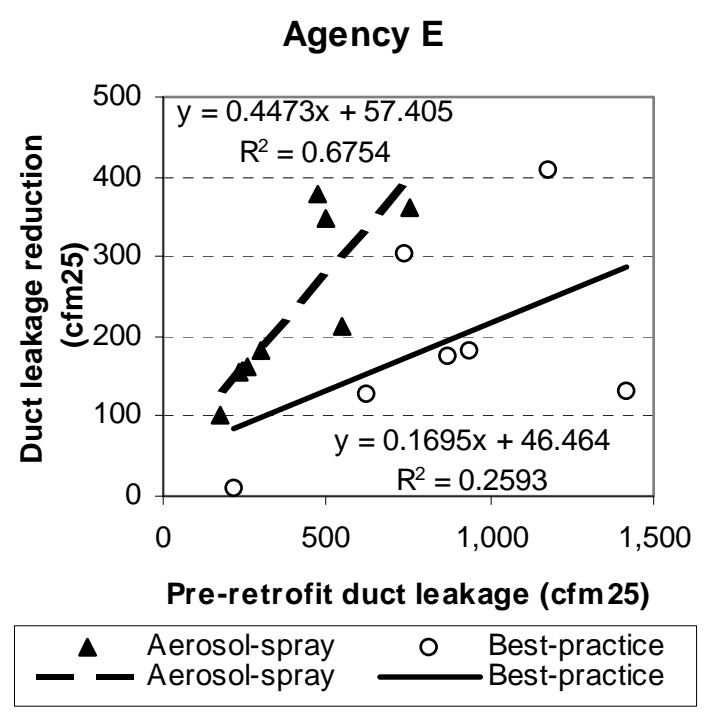

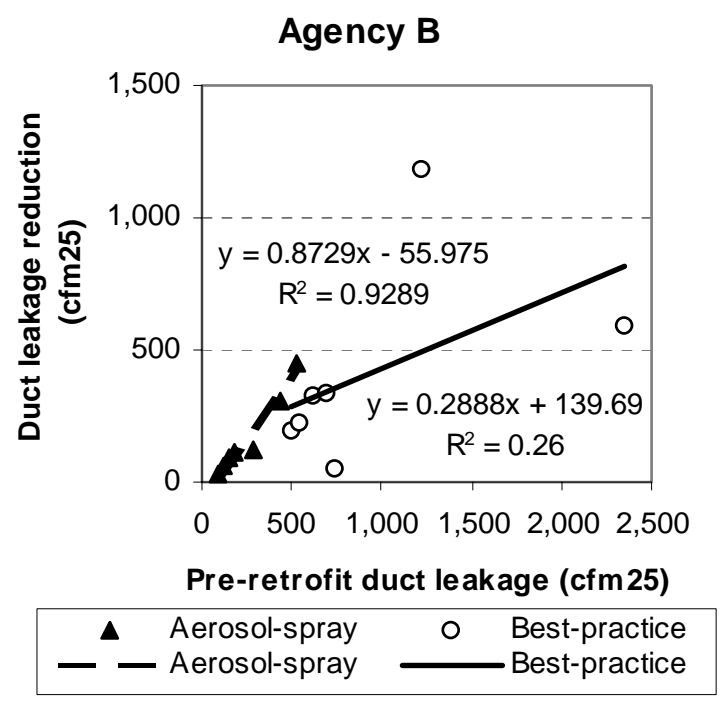

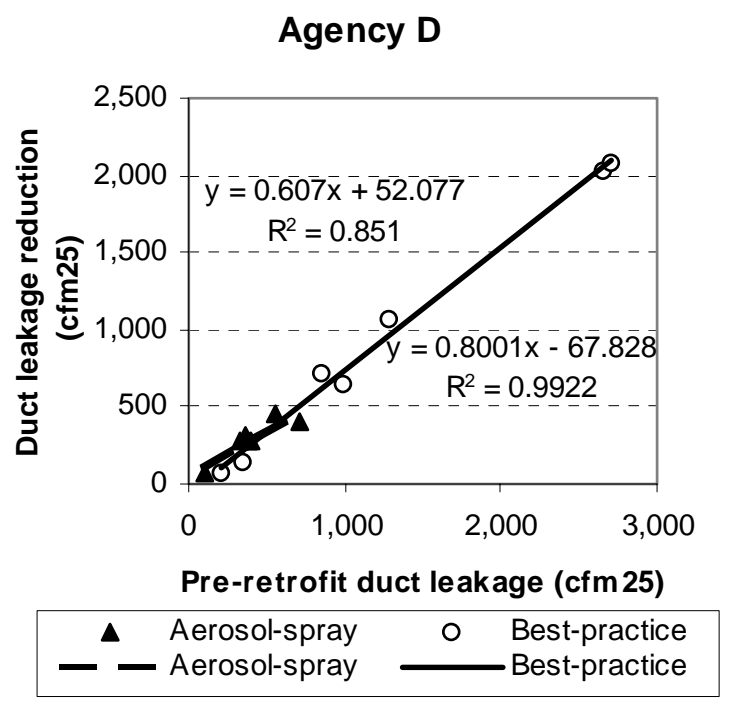

Fig. 5.11. Comparison of total duct leakage reductions (based on supply pressure) achieved by each weatherization agency using the aerosol-spray and bestpractice technologies. 



\section{PRESSURE PAN MEASUREMENTS}

Weatherization crews routinely use pressure pan measurements in implementing basic duct-sealing approaches to determine if ducts should be sealed and to locate potential leakage sites. Pressure pan measurements were made in this field test as discussed in Sect. 3.2.2. These measurements provide an indirect assessment of the impact duct sealing has had, supplementing the direct measurements of duct leakage discussed in Sect. 5. Seventy-two houses had both pre- and post-retrofit pressure pan readings that could be analyzed.

\subsection{ALL HOUSES}

In each house, the pressure pan readings (supply and returns) were added together to obtain a total value for the house. As is indicated in Table 6.1, duct sealing was effective in reducing the average pre-retrofit value of $61 \mathrm{~Pa}$ by $62 \%$. As shown in Fig. 6.1, house values were evenly distributed between 0 and $100 \mathrm{~Pa}$ before duct sealing and were predominantly less than $30 \mathrm{~Pa}$ following retrofit.

Table 6.1. Average total house pressure pan readings $(\mathbf{P a})$

\begin{tabular}{|l|c|c|c|c|}
\hline \multicolumn{1}{|c|}{ House type } & Pre-retrofit & Post-retrofit & Reduction & $\begin{array}{c}\text { Percent } \\
\text { reduction }\end{array}$ \\
\hline \hline All houses & 61 & 23 & 38 & $62 \%$ \\
\hline Aerosol group & 50 & 18 & 32 & 64 \\
\hline Best-practice group & 71 & 27 & 44 & 62 \\
\hline
\end{tabular}

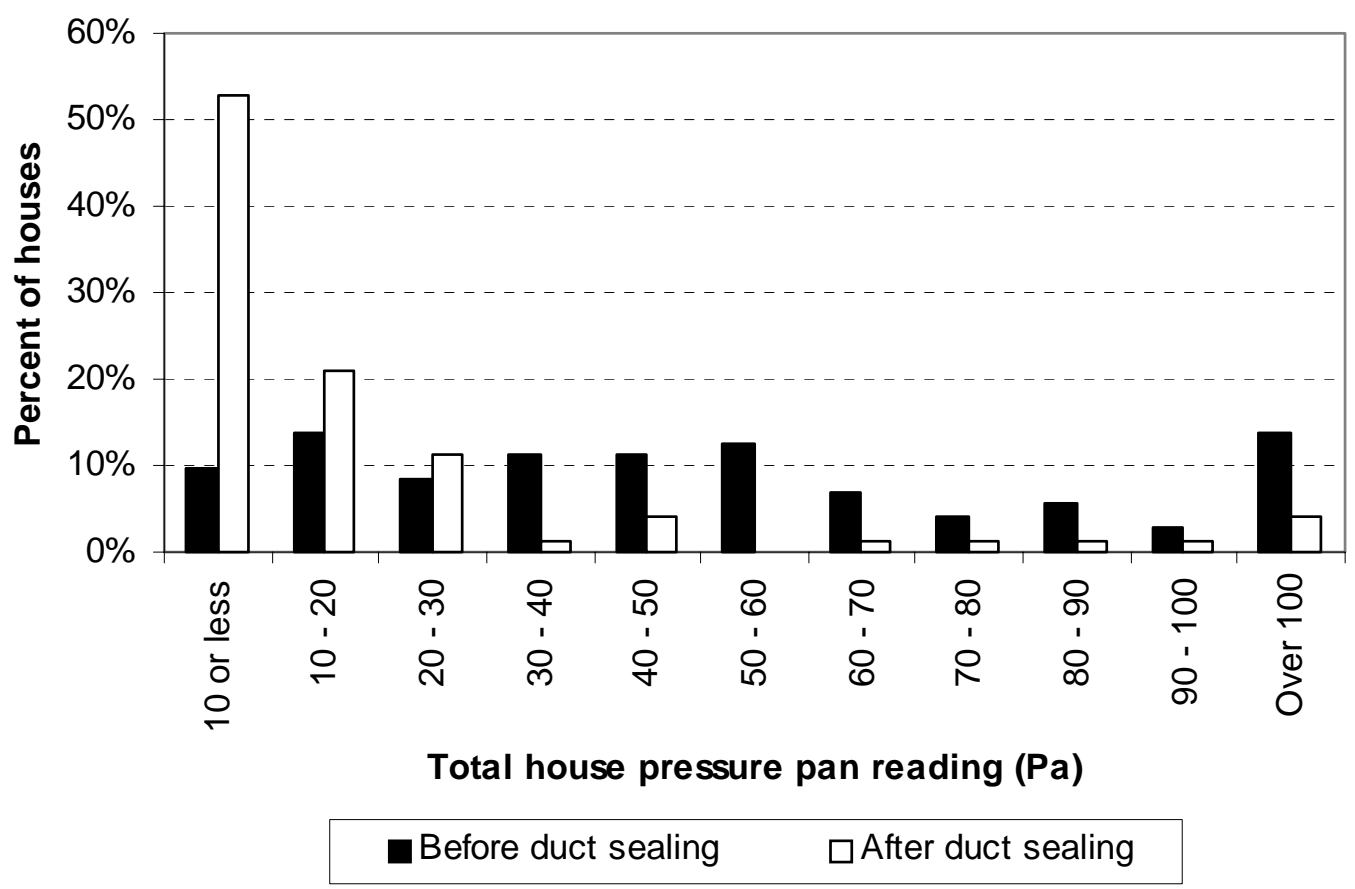

Fig. 6.1. Pre- and post-retrofit distributions of total house pressure pan readings. 
An average value was also calculated for each house to account for houses that had a different number of registers in them. The average pre-retrofit value was 7.2, and the average post-retrofit value was 3.2. This represents a reduction of $4 \mathrm{~Pa}(56 \%)$ due to duct sealing. A slightly bell-shaped distribution between 0 and 11 is shown in Fig. 6.2 for these house averages before retrofit, with average values for most houses being less than $3 \mathrm{~Pa}$ after retrofit.

Pressure pan readings of $\geq 1.0 \mathrm{~Pa}$ are often interpreted to mean that a sealable leak probably exists behind that register, whereas a value of $<1.0$ indicates that the measured portion of the duct system is relatively tight. As shown in Table $6.2,81 \%$ of all the registers had a pressure pan reading of $\geq 1.0 \mathrm{~Pa}$ before retrofit; duct sealing reduced this by about half.

Houses with three registers $\geq 1.0 \mathrm{~Pa}$ are often considered good candidates for duct sealing. Before retrofit, $89 \%$ of the houses in the field test had three or more registers with a pressure pan reading $\geq 1.0 \mathrm{~Pa}$ (see Table 6.3 and Fig. 6.3). After duct sealing, this percentage dropped to 53\%. Table 6.3 and Fig. 6.3 also show that only $10 \%$ of the houses had only one or no registers with a pressure pan reading $\geq 1.0 \mathrm{~Pa}$. Duct sealing increased this value to $36 \%$ of the houses following retrofit.

\subsection{COMPARISON BETWEEN BEST-PRACTICE AND AEROSOL HOUSES}

The average pre-retrofit value of the total pressure pan readings was $50 \mathrm{~Pa}$ in the aerosol-treated homes and $71 \mathrm{~Pa}$ in the best-practice homes (see Table 6.1). This supports the findings based on the duct leakage measurements (see Sect. 5.2) that the two groups of houses were not equivalent prior to duct sealing and makes it difficult to compare average post-retrofit values or percentage reductions for the two groups. Despite the lack of equivalency between the groups, the pressure pan readings indicate that the aerosol-spray approach provided an improved performance (Fig. 6.4). The distributions of the total pressure pan readings were about the same for the two groups of houses before duct sealing. Following duct sealing, $70 \%$ of the houses treated with the aerosol-spray technique had total readings that were less than $10 \mathrm{~Pa}$, compared with only about $30 \%$ of the houses

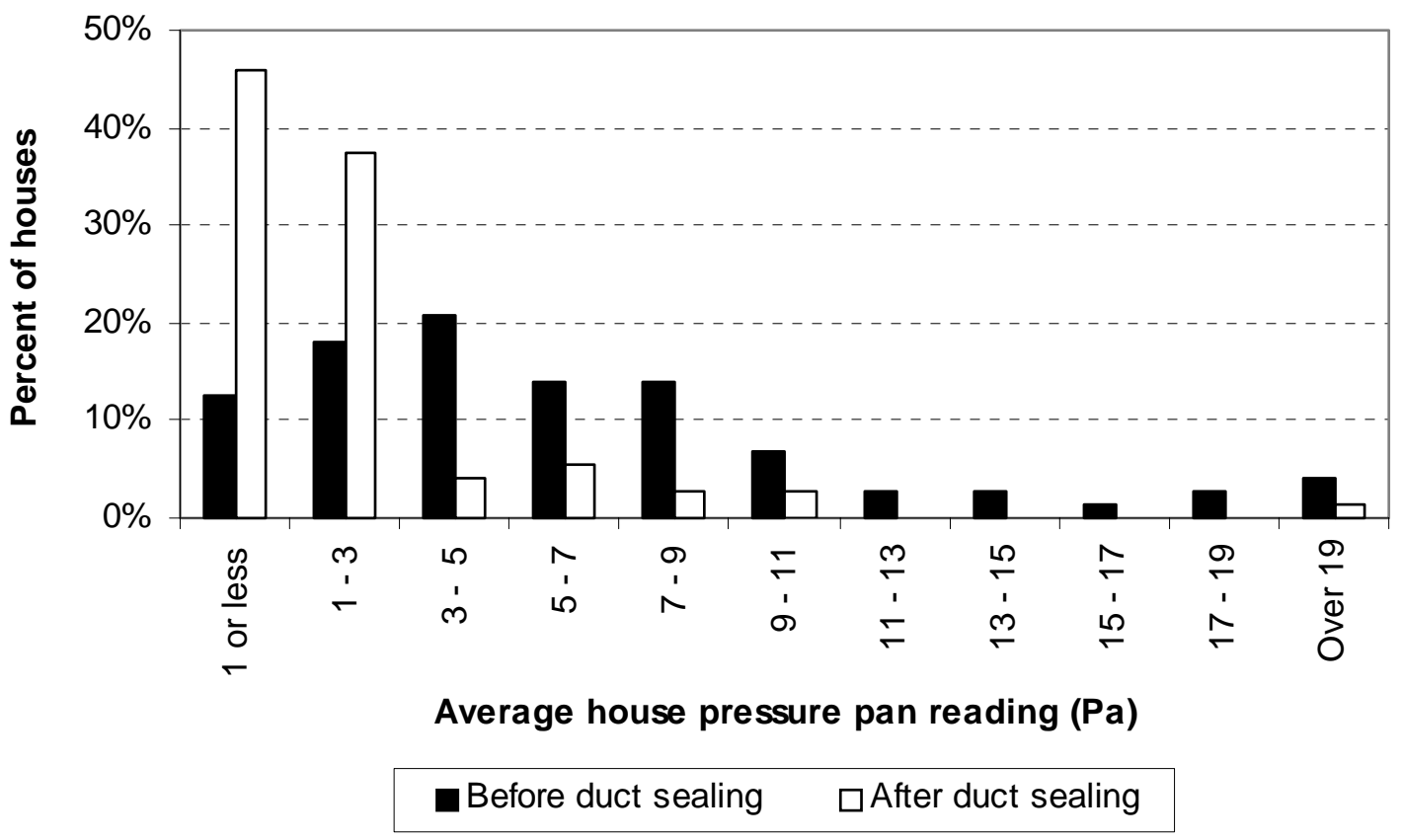

Fig. 6.2. Pre- and post-retrofit distributions of average house pressure pan readings. 
Table 6.2. Percentage of registers with pressure pan readings $\geq 1.0 \mathrm{~Pa}$

\begin{tabular}{|l|c|c|c|c|}
\hline \multicolumn{1}{|c|}{ House type } & Pre-retrofit & Post-retrofit & Reduction & $\begin{array}{c}\text { Percent } \\
\text { reduction }\end{array}$ \\
\hline \hline All houses & 81 & 45 & 36 & 44 \\
\hline Aerosol group & 74 & 33 & 41 & 55 \\
\hline Best-practice group & 89 & 57 & 32 & 36 \\
\hline
\end{tabular}

Table 6.3. Percentage of houses with registers $\geq 1.0 \mathrm{~Pa}$

\begin{tabular}{|l|c|c|c|c|}
\hline \multirow{2}{*}{ House type } & \multicolumn{2}{|c|}{ 0-1 registers $\geq \mathbf{1 . 0}$ Pa } & \multicolumn{2}{c|}{ 3 or more registers $\geq \mathbf{1 . 0}$ Pa } \\
\cline { 2 - 5 } & Pre-retrofit & Post-retrofit & Pre-retrofit & Post-retrofit \\
\hline \hline All houses & 10 & 36 & 89 & 53 \\
\hline Aerosol group & 14 & 54 & 84 & 38 \\
\hline Best-practice group & 6 & 17 & 94 & 69 \\
\hline
\end{tabular}

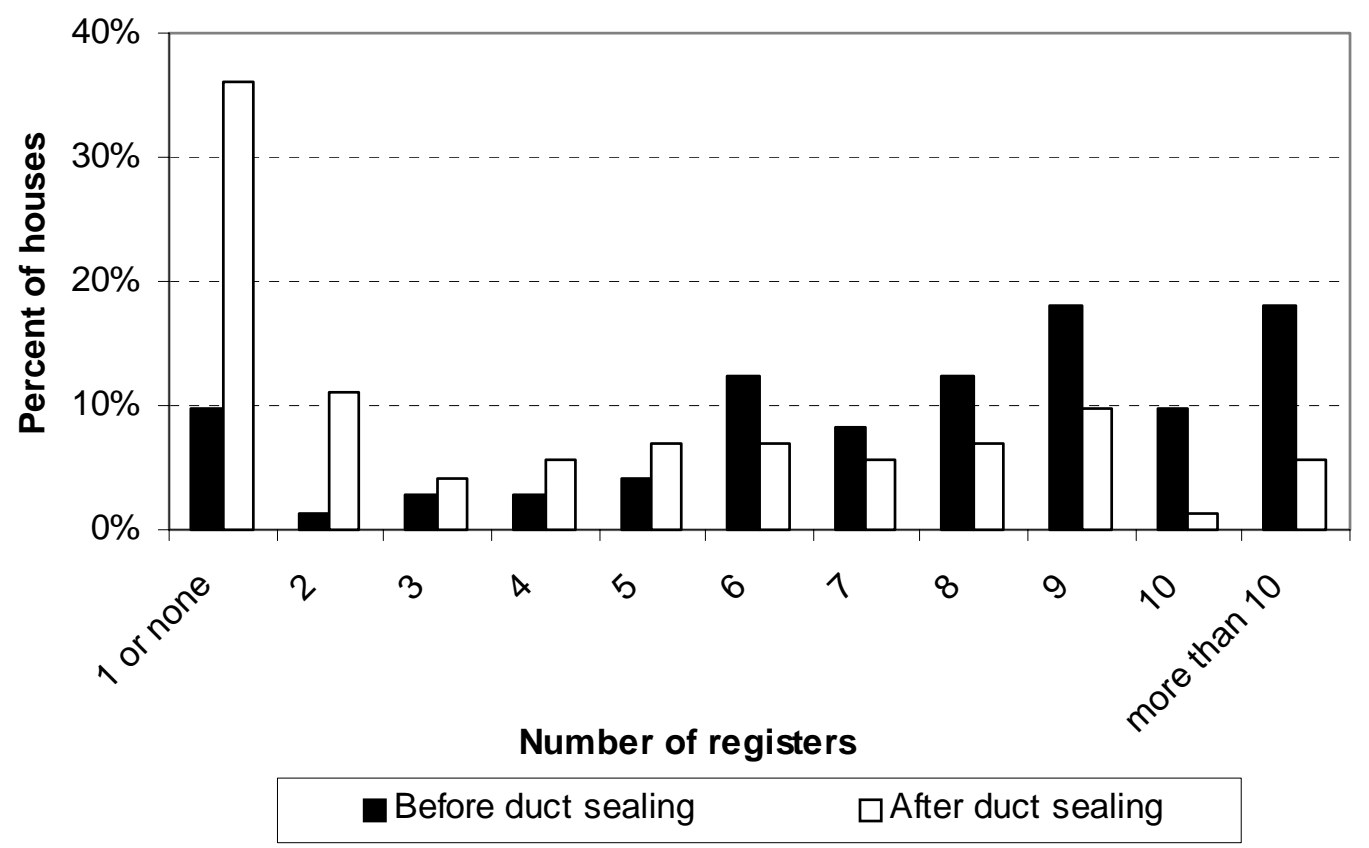

Fig. 6.3. Pre- and post-retrofit distributions of the number of registers in a house with a pressure pan reading $\geq 1.0 \mathrm{~Pa}$. 


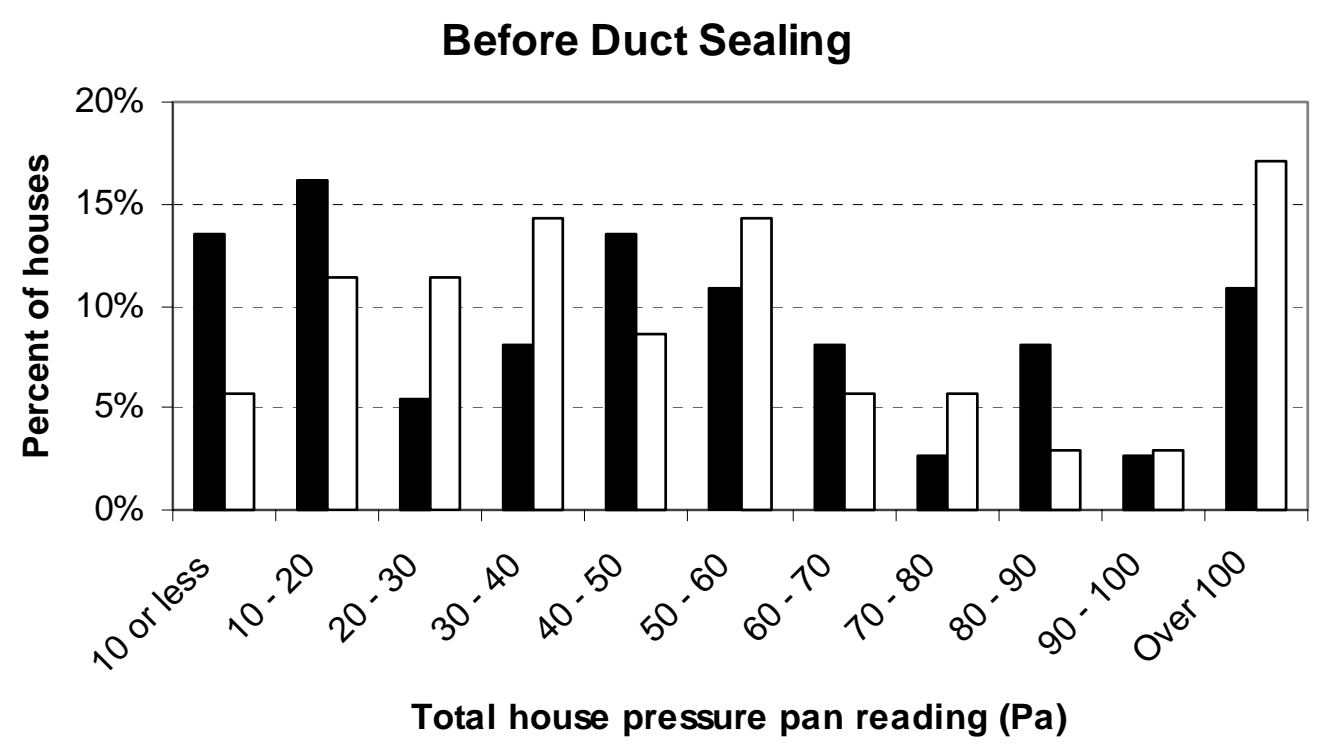

Aerosol-spray $\quad \square$ Best-practice

(a)

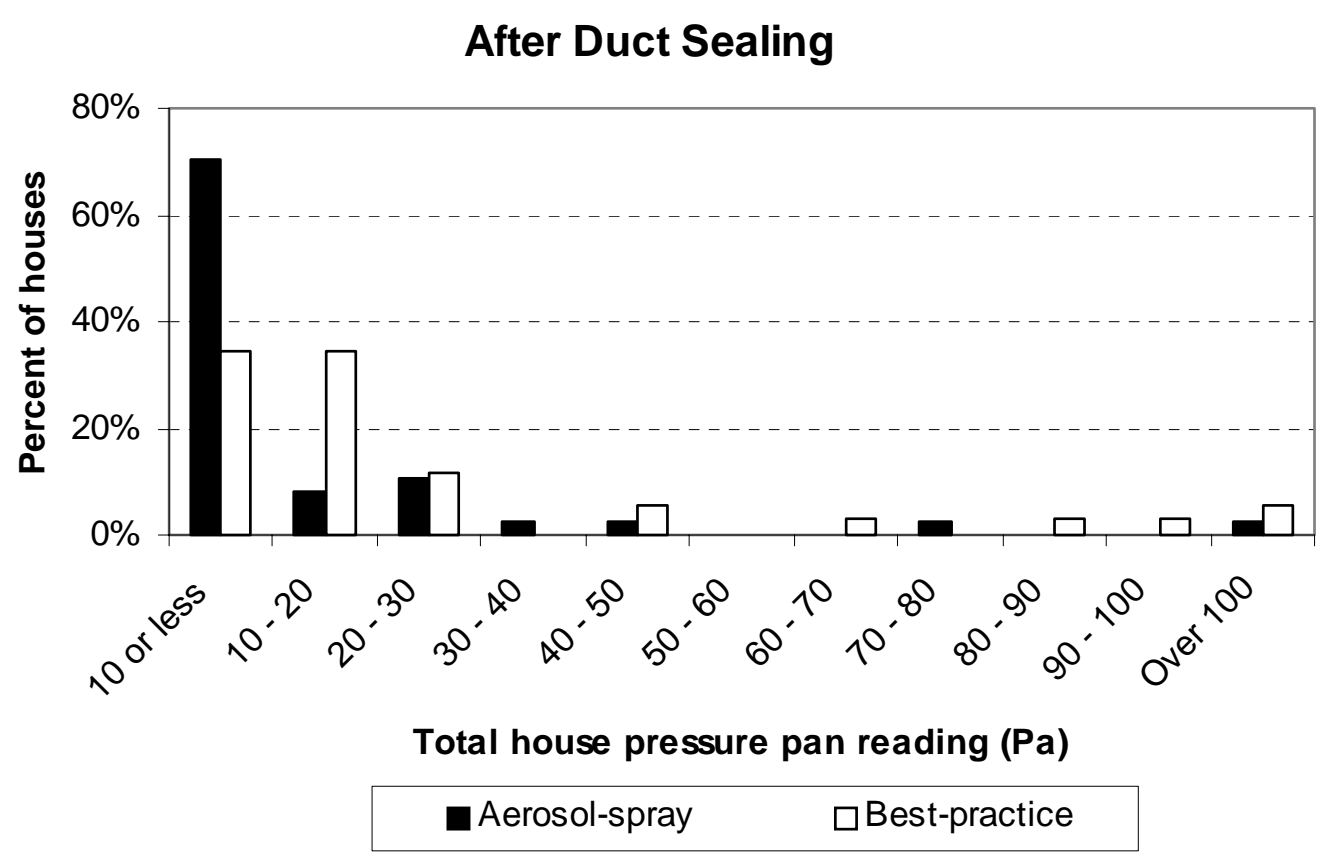

(b)

Fig. 6.4. Pre- and post-retrofit distributions of total pressure pan readings for the aerosolspray-treated and best-practice-treated houses. 
treated according to the best-practice approach. Similar results were obtained when the average pressure pan readings for each house were examined.

As shown in Table 6.2, $89 \%$ of all the registers in the best-practice group had a pressure pan reading of $\geq 1.0 \mathrm{~Pa}$, but only $74 \%$ in the aerosol group did. This again indicates that the aerosol group of houses had tighter ducts before retrofit than did the best-practice houses.

The percentage of houses with no more than one register with a pressure pan reading $\geq 1.0 \mathrm{~Pa}$ increased dramatically in the aerosol group following retrofit, from 14 to 54\% (Table 6.3), while only limited improvement was observed in the best-practice homes (from 6 to 17\%). In addition, the percentage of homes with three or more registers with a pressure pan reading $\geq 1.0 \mathrm{~Pa}$ dropped markedly in the aerosol group (from 84 to 38\%), while a much smaller drop occurred in the bestpractice group (from 94 to $69 \%$ ). 



\section{ENERGY DATA}

As discussed in Sect. 3.2.1, data were collected on each house and analyzed to estimate the energy consumption before and after duct sealing. Pre- and post-retrofit annual energy consumption could be estimated for 65 of the 80 houses in the original sample. (Some houses were dropped from the sample because of normal attrition associated with moving, illnesses, and emergency repairs required to the space-heating systems; in other cases, reliable energy-use models could not be developed.) It should be emphasized that the group statistics presented in this section were not adjusted by a control group that could account for occupant factors, such as changes in indoor temperatures, that would affect energy use before and after duct sealing.

\subsection{ALL HOUSES}

As shown in Table 7.1, the houses in the sample reduced energy use by an average of 65 therms per year, or $5.5 \%$, after the duct sealing performed in this field test. These values are significantly different from zero at the $95 \%$ confidence level. Median values presented in Table 7.2 indicate similar reductions. Median values are useful when small sample sizes are examined because they reduce the impact that a few houses with extreme values can have on the means.

Table 7.1. Estimates of house energy use (therms): mean values

\begin{tabular}{|c|c|c|c|c|}
\hline \multicolumn{1}{|c|}{ House type } & Pre-retrofit & Post-retrofit & Reduction & $\begin{array}{c}\text { Percent } \\
\text { reduction }\end{array}$ \\
\hline \hline All houses (65) & 907 & 842 & 65 & $5.5 \%$ \\
\hline Houses with all ducts inside (21) & 979 & 927 & 53 & 5.0 \\
\hline Houses with outside ducts (44) & 872 & 801 & 71 & 5.8 \\
\hline Some outside (13) & 706 & 599 & 107 & 8.8 \\
\hline Just in crawl space (15) & 1120 & 1029 & 91 & 6.5 \\
\hline Just in basement (16) & 775 & 752 & 23 & 2.6 \\
\hline
\end{tabular}

Table 7.2. Estimates of house energy use (therms): median values

\begin{tabular}{|c|c|c|c|c|}
\hline \multicolumn{1}{|c|}{ House type } & Pre-retrofit & Post-retrofit & Reduction & $\begin{array}{c}\text { Percent } \\
\text { reduction }\end{array}$ \\
\hline \hline All houses (65) & 819 & 764 & 36 & $4.7 \%$ \\
\hline Houses with all ducts inside (21) & 985 & 865 & 25 & 2.9 \\
\hline Houses with outside ducts (44) & 688 & 628 & 44 & 8.2 \\
\hline Some outside (13) & 545 & 476 & 38 & 9.4 \\
\hline Just in crawl space (15) & 819 & 824 & 70 & 9.6 \\
\hline Just in basement (16) & 669 & 600 & 30 & 4.7 \\
\hline
\end{tabular}


Savings for individual houses were quite variable. They were not dependent on any of the four duct leakage reductions measured in each house (see Fig. 7.1) nor on initial duct leakage as exemplified in Fig. 7.2, which displays total duct leakage based on supply pressure. The absence of such correlation was also found in another field test (Lerman 1998). Variability of this type and degree as observed in field tests of household energy savings is usually due to many factors, including differences in indoor temperatures among houses, indoor temperatures before and after retrofit, and the amount of retrofit work performed. Three other reasons for energy use variations that this analysis does not fully take into account are the following:

- Energy savings should be dependent only on the portion of duct leakage lost to the outside.

- Some of the energy lost from duct leakage to the outside can find its way back into the house.

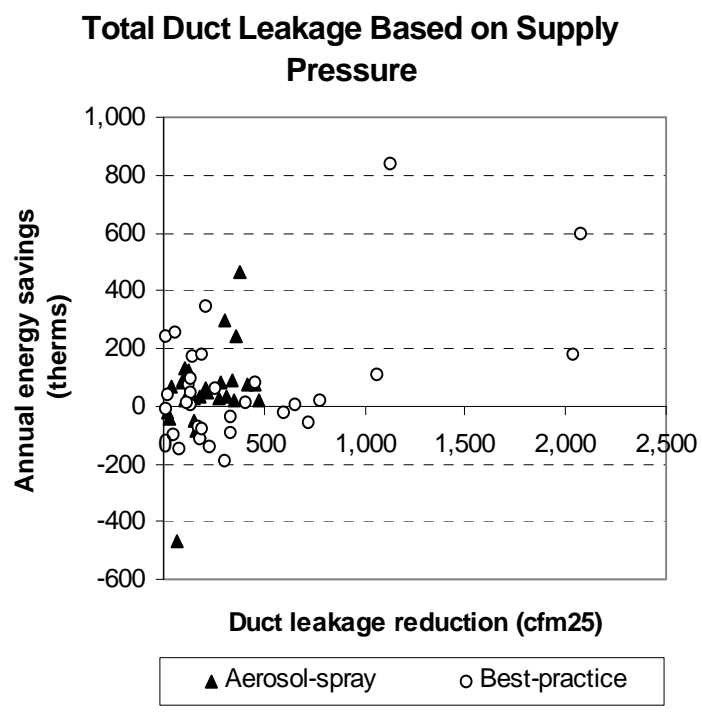

(a)

\section{Duct Leakage to the Outside Based on Supply Pressure}

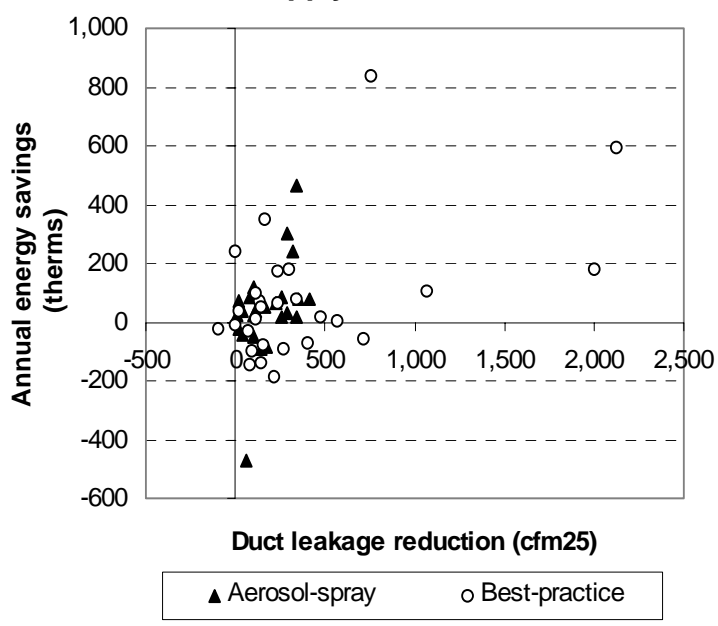

(c)

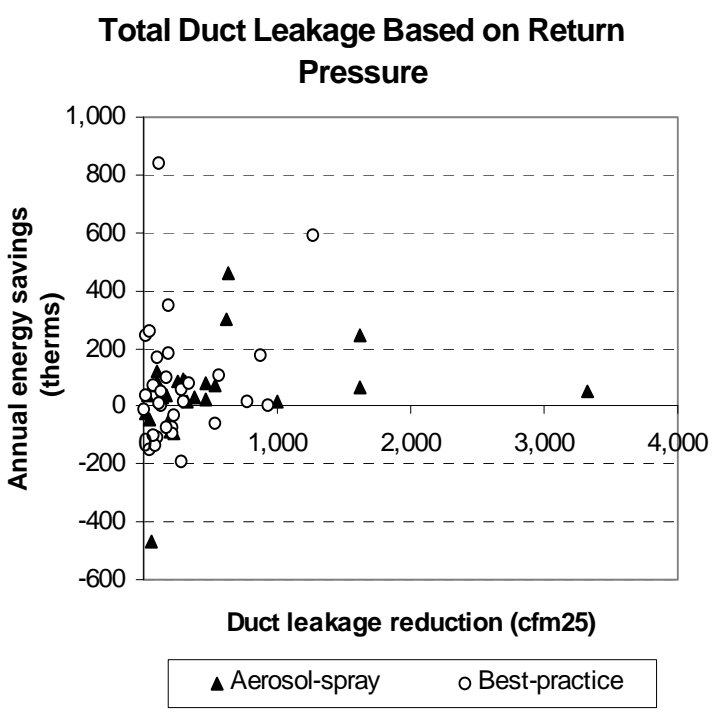

(b)

\section{Duct Leakage to the Outside Based on} Return Pressure

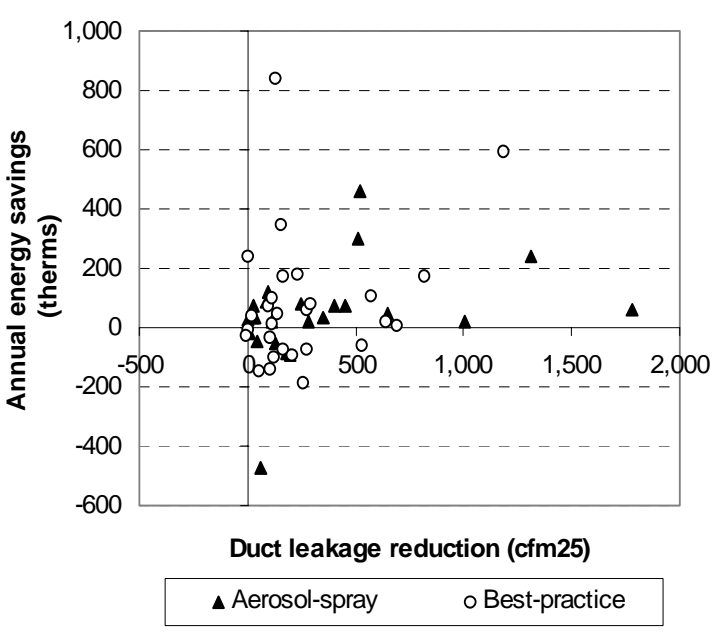

(d)

Fig. 7.1. Energy savings as a function of duct leakage reduction. 


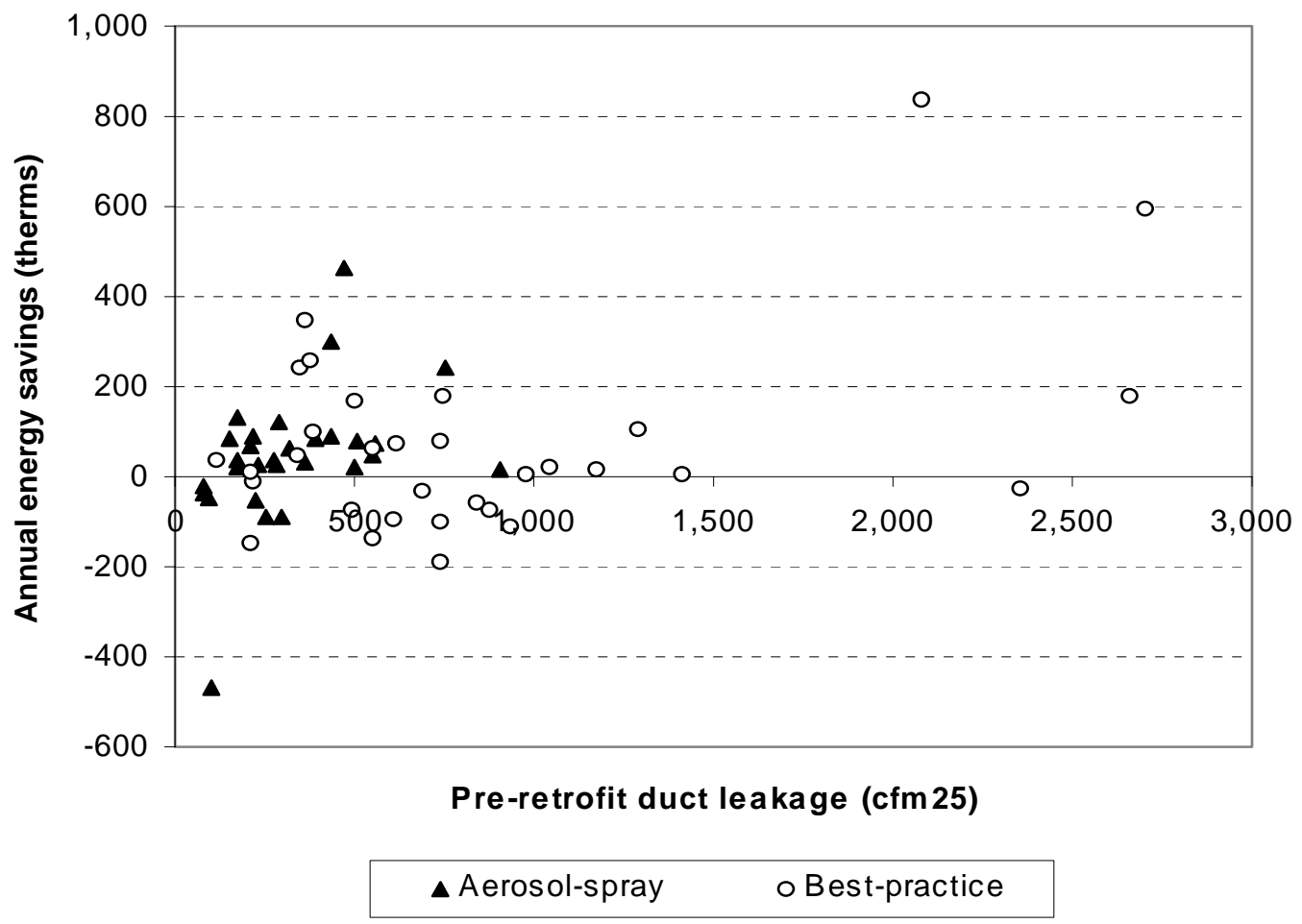

Fig. 7.2. Energy savings as a function of pre-retrofit total duct leakage based on supply pressure.

- Sealing duct leakage to the inside can improve air distribution and comfort, but it may only indirectly improve the energy efficiency of the heating system.

In houses with crawl spaces, researchers have estimated that about half of the heat lost from duct leakage occurring in an uninsulated crawl space makes its way back into the house (ASHRAE 2001). This occurs because the crawl space is warmer than it would be if no leaks were present. As a result, there is less heat loss through the uninsulated floor, and air infiltrating the house through holes in the floor is now warmer than it would have been. Because the field test houses were not weatherized until after the field test, it is likely that many houses with crawl spaces had uninsulated floors.

In houses with basements, field test measurements of duct leakage to the outside were made by isolating the basement from the house regardless of whether the basement and ducts located in the basement were "inside" or "outside" the conditioned volume of the house (see Sect. 3.2.2). In houses where the basement is truly part of the conditioned volume (as evidenced by having supply and/or return registers in the basement), the actual duct leakage to the outside would normally be zero (assuming that ducts were not located in other locations connected to the outside). In houses where the basement is outside the conditioned volume of the structure, researchers again have estimated that about half of the heat lost from duct leakage occurring in such a basement makes its way back into the house as described above for crawl spaces (ASHRAE 2001).

Thus, to study the variability in energy savings among houses, the houses were divided into two groups: those with ducts completely inside the house and those with at least some ducts located outside the conditioned volume of the house. Houses with basements were assumed to have ducts completely inside the house only if supply and/or return registers were in the basement and no ducts 
were located in crawl spaces, attics, carports, garages, or other outside locations. Other houses in the "inside" group were those identified as having all interior duct work (although it was recognized that even these houses can have outside duct leakage because, for example, return plenums inside the house are connected to the attic through interior walls). All other houses were assigned to the "outside"group.

The "outside" group was further divided into three subgroups: basement homes with ducts located only in the basements or inside the houses, crawl space homes with ducts located only in the crawl space or inside the house, and all remaining homes with some ducts located in attics, garages, carports, and other outside locations. Researchers estimate that most of the heat lost from ducts located in attics, garages, and other outside locations is completely lost and does not make its way back into the house.

Tables 7.1 and 7.2 also provide summary data for these groups and subgroups. Although there are no statistical differences between groups because of the scatter in individual house savings (Fig. 7.3) and the small number of houses in each group, some expected trends are indicated. First, houses with ducts completely inside the conditioned volume had lower savings than the other houses. Second, houses with ducts that were clearly located outside the conditioned space of the home (the "some outside" group, where heat losses do not make it back to the house) had larger savings (9\%) than houses with ducts only in basements and only in uninsulated crawl spaces (where some of the heat loss makes its way back into the house).

As shown in Fig. 7.3, annual savings for houses with ducts located completely inside the house generally ranged from -200 to 200 therms, the same range observed for most of the houses with ducts located outside the conditioned volume of the house. [The data are plotted in Fig. 7.3(b) as a function of outside duct leakage as measured in the field test to show the scatter present, even though the actual outside duct leakage is probably zero.] There is no strong correlation between reduction in duct leakage and savings $\left(\mathrm{R}^{2}=0.25\right)$ for just those houses with ducts located outside the conditioned space where the outside duct leakage measurements are correct [Fig. 7.3(a)].
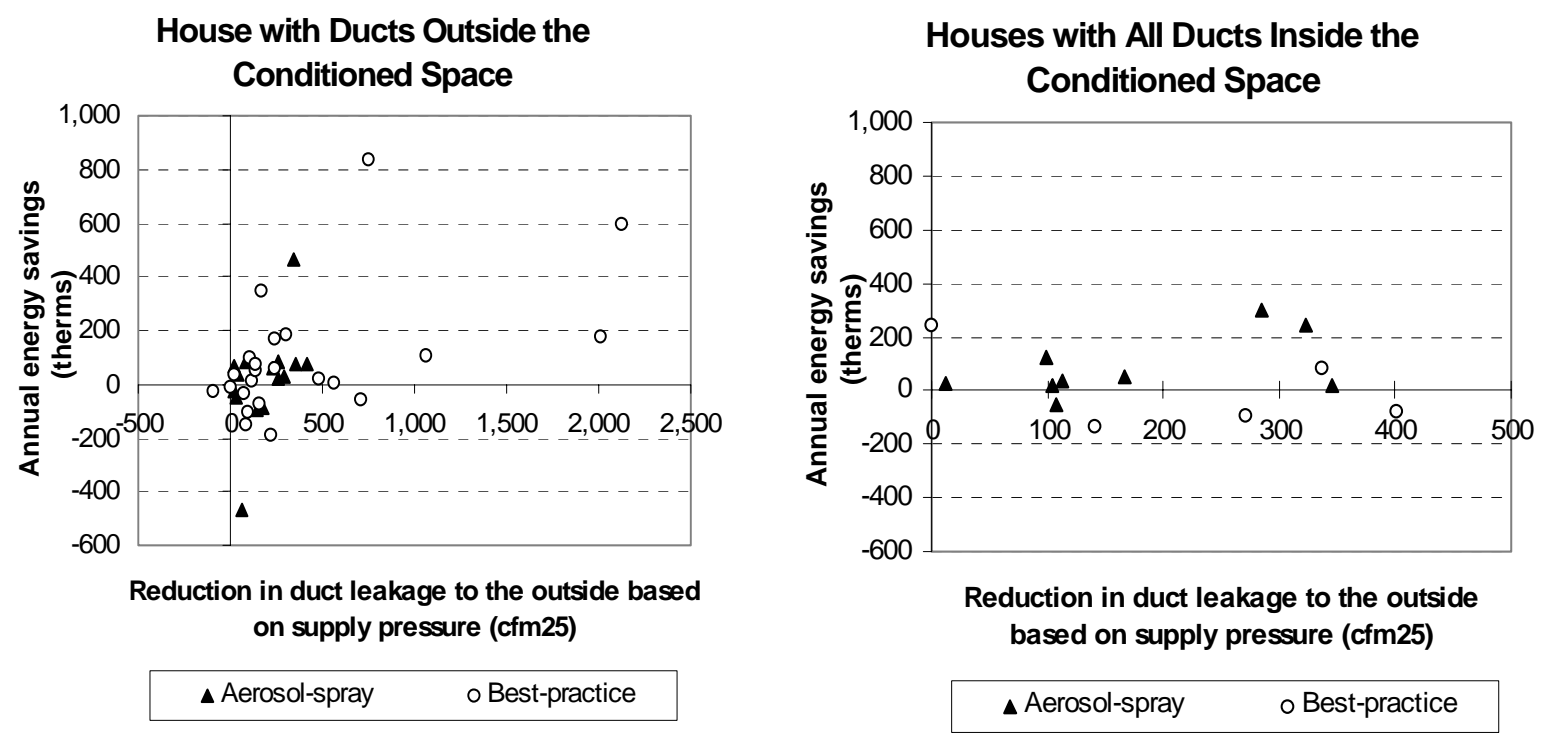

Fig. 7.3. Annual savings for houses with ducts located completely inside the conditioned space of the house and for those with some ducts located outside the conditioned space. 


\subsection{COMPARISON BETWEEN BEST-PRACTICE AND AEROSOL HOUSES}

No conclusions could be drawn concerning energy saving differences between the two duct-sealing methods used in this study because the scatter observed in the savings for individual homes was too great, the two groups were not equivalent to begin with (initial duct leakages in the two groups of houses differed), and no correlation could be established between the reduction in duct leakage and energy savings. However, the larger reductions in duct leakage measured in the homes using the aerosol-spray technology would be expected to translate into higher energy savings compared with the homes using just the best-practice approach.

\subsection{COMPARISON AMONG WEATHERIZATION AGENCIES}

As shown in Tables 7.3 and 7.4, average savings for individual agencies were variable. Savings for Agencies $\mathrm{A}$ and $\mathrm{C}$ were fairly high; for the other three agencies savings were just slightly greater than zero. Some of this variation is due to the house types and duct locations encountered by each agency. As observed before, there is no correlation between the average duct leakages achieved by the agency and its average energy savings.

Table 7.3. Estimates of house energy use (therms) by weatherization agency: mean values

\begin{tabular}{|c|c|c|c|c|}
\hline Agency & Pre-retrofit & Post-retrofit & Reduction & $\begin{array}{c}\text { Percent } \\
\text { reduction }\end{array}$ \\
\hline \hline A & 837 & 721 & 116 & $13.9 \%$ \\
\hline B & 1022 & 999 & 23 & 2.3 \\
\hline C & 665 & 543 & 122 & 18.4 \\
\hline D & 1209 & 1169 & 40 & 3.3 \\
\hline E & 902 & 883 & 18 & 2.0 \\
\hline
\end{tabular}

Table 7.4. Estimates of house energy use (therms) by weatherization agency: median values

\begin{tabular}{|c|c|c|c|c|}
\hline Agency & Pre-retrofit & Post-retrofit & Reduction & $\begin{array}{c}\text { Percent } \\
\text { reduction }\end{array}$ \\
\hline \hline A & 833 & 754 & 87 & $15.4 \%$ \\
\hline B & 968 & 951 & -30 & -2.6 \\
\hline C & 560 & 492 & 62 & 11.6 \\
\hline D & 798 & 832 & 50 & 4.7 \\
\hline E & 727 & 781 & 5 & 0.5 \\
\hline
\end{tabular}





\section{ECONOMICS AND SAFETY}

\subsection{REPAIR TIMES AND COSTS}

Information was collected on 76 houses (37 best-practice houses and 39 aerosol houses) on the elapsed time required to duct-seal each house and the crew-time spent performing manual duct sealing. The elapsed time was defined as the time from the start of duct sealing (after all diagnostics were performed) until all duct sealing work was completed (before equipment was packed up). The crew-time spent performing manual duct sealing was defined as total crew time. In the best-practice houses, crew-time was typically the number of crew members at the house times the elapsed time spent duct sealing. In the houses treated with the aerosol-spray technique, this value was just the total crew-time spent manually sealing the ducts and does not include any time spent working with the aerosol equipment.

Using these definitions, average repair times and costs for the two techniques are shown in Table 8.1 Only data on 59 houses are reported in the table. Agency A did not record elapsed times for 7 aerosol houses, and Agency E did not properly report crew-times for 8 aerosol houses (all crew-time was reported as two times the elapsed time even though work descriptions noted that little or no manual sealing was performed). Thus, these 15 houses are not included in the group statistics for the aerosolspray treated houses. (The group statistics for the best-practice homes in Table 8.1 include houses from Agencies A and E, but no significant change occurs if the best-practice houses from these two agencies are dropped.) In addition, both elapsed times and crew-times were not available for two best-practice houses from two different agencies.

As seen in Table 8.1, the average elapsed time to perform repairs in the aerosol-spray houses was 98 min, an average time that was also reported in another study of the aerosol-spray system (Modera et al. 1996). This elapsed time was about $67 \%$ less than the elapsed time needed to seal ducts in the best-practice houses (147 $\mathrm{min}$ ).

Furthermore, significant labor savings are indicated from use of the aerosol technology. The average crew-time needed to perform manual air sealing in the aerosol houses was $66 \mathrm{~min}$, which again is very consistent with an average time of 65 min reported by Modera et al. (1996). This time to perform manual sealing in the aerosol houses was $20 \%$ of the average crew-time needed in the bestpractice houses (330 min), or 264 crew-minutes ( 4.4 crew-hours) less. The crew-minutes spent manually sealing ducts in the best-practice houses was greater than 720 minutes (12 crew-hours) in

Table 8.1. Average repair times and costs for the best-practice and aerosol-spray approaches

\begin{tabular}{|c|c|c|c|c|c|}
\hline House type & $\begin{array}{c}\text { Number of } \\
\text { houses }^{a}\end{array}$ & $\begin{array}{c}\text { Elapsed } \\
\text { repair time } \\
(\mathbf{m i n})\end{array}$ & $\begin{array}{c}\text { Crew-time for } \\
\text { manual } \\
\text { sealing } \\
(\mathbf{m i n})\end{array}$ & $\begin{array}{c}\text { Crew-time per } \\
\text { elapsed time }\end{array}$ & $\begin{array}{c}\text { Material costs } \\
\text { for manual } \\
\text { repair }\end{array}$ \\
\hline \hline Best-practice & 35 & 147 & 330 & 2.2 & $\$ 50$ \\
\hline Aerosol-spray & 24 & 98 & 66 & 0.7 & $\$ 19$ \\
\hline
\end{tabular}

${ }^{a}$ Data was unavailable or improperly recorded for 17 houses in the sample; hence, the averages include only 59 houses. 
about $15 \%$ of the homes (spread across three weatherization agencies). For comparison, the greatest amount of labor spent manually sealing ducts in the aerosol houses was 360 crew-minutes (6 crewhours).

A value for the crew-time spent manually sealing ducts per elapsed time was calculated for each group of houses. In the best-practice houses, more than 2 crew members worked on average for the duration of the time spent air-sealing the ducts, whereas in the aerosol houses, less than one person worked on average to manually seal ducts. These data suggest that, once the aerosol-spray equipment is set up, a total of 98 minutes would be required for one person to operate the aerosol-spray equipment to seal leaks automatically and perform the necessary manual duct sealing. By contrast, 330 crew-minutes could be required to seal ducts manually — or 232 crew-minutes (3.9 crew-hours) more than would be necessary with the aerosol approach.

As Table 8.2 indicates, labor savings are likely to be agency-dependent. Average repair times using the aerosol approach are fairly consistent among the agencies, although Agency B spent proportionally less time performing manual repairs than the other agencies. Two agencies (A and D) spent twice as much time as the other three agencies, and considerably more crew-time, to seal ducts using best-practice approaches, although all agencies dedicated between two and three people on average to seal the ducts during the repair period.

Setup, tear-down, and diagnostic times must also be considered in determining the overall or total labor costs associated with a particular duct-sealing technology. These times could not be determined from the field test because crew members were performing these tasks while other diagnostics were performed. Two agencies reported setup times of $1 \frac{1}{2}$ to 2 hours by multi-member crews on the first houses where they used the equipment, with one agency saying that setup times decreased to 30 min on the last houses once they had become familiar with the equipment (see Sect. 9.1). Assuming a two-person crew, these times are consistent with times reported by Modera et al. (1996) in another study of the aerosol-spray technology; these researchers found that 3 person-hours were required for setup for the first 21 houses used in their study and 1.9 person-hours for the next 17 systems. The crew-hours required to perform setup, diagnostics, and teardown are probably greater for the aerosol-

Table 8.2. Average repair times (minutes) for each weatherization agency

\begin{tabular}{|c|c|c|c|c|c|c|}
\hline \multirow[b]{2}{*}{ Agency } & \multicolumn{3}{|c|}{ Best-practice approach } & \multicolumn{3}{|c|}{ Aerosol-spray approach ${ }^{a}$} \\
\hline & $\begin{array}{c}\text { Elapsed } \\
\text { repair time }\end{array}$ & Crew-time & $\begin{array}{c}\text { Crew-time } \\
\text { to elapsed } \\
\text { time }\end{array}$ & $\begin{array}{c}\text { Elapsed } \\
\text { repair time }\end{array}$ & Crew-time & $\begin{array}{c}\text { Crew-time } \\
\text { to elapsed } \\
\text { time }\end{array}$ \\
\hline A & 238 & 483 & 3.0 & - & - & - \\
\hline B & 110 & 251 & 2.3 & 111 & 45 & 0.4 \\
\hline $\mathrm{C}$ & 113 & 333 & 3.0 & 60 & 64 & 1.1 \\
\hline $\mathrm{D}$ & 216 & 454 & 2.1 & 90 & 94 & 1.0 \\
\hline E & 77 & 163 & 2.1 & 101 & - & - \\
\hline
\end{tabular}

${ }^{a}$ Blanks represent aerosol-spray-treated houses for which elapsed time or crew-time was unrecorded or improperly recorded. 
spray technology than for the conventional, best-practice technology. However, the additional time for these activities is probably much less than the four additional crew-hours needed to seal the ducts under the best-practice approach.

As shown in Table 8.1, average material costs associated with the manual portion of duct sealing were greater for the best-practice houses than for the aerosol houses ( $\$ 50$ and $\$ 19$, respectively). However, assuming a material cost of $\$ 15$ to $\$ 20$ per house for the aerosol-spray sealant, the total material costs associated with both methods are about the same.

\subsection{EQUIPMENT COSTS}

The aerosol-spray technology was developed by Lawrence Berkeley National Laboratory (LBNL) with funding from DOE, the Environmental Protection Agency, and others. The University of California (which manages LBNL) was granted a patent in 1999 on this technology. Aeroseal now holds an exclusive license to use this technology on residential and small commercial buildings.

Although the technology itself was developed by LBNL, Aeroseal developed the current version of the equipment and software used in the field test to apply the technology in the field. Aeroseal began licensing the technology in January 1999 to a limited number of experienced HVAC contractors in different geographic and market areas through a franchise arrangement. The cost of a franchise is about $\$ 20,000$. This cost includes the equipment, software, and training on how to implement the technology. Under the franchise agreement, the franchisee must meet minimum production quotas set by Aeroseal, provide Aeroseal with data collected on each house sealed using the technology for quality control purposes, and pay Aeroseal a royalty fee for each house sealed using the technology.

For the conventional, best-practice approach, several national manufacturers produce duct blowers and related equipment to duplicate the diagnostics performed in this field test. The cost of duct blowers are about \$2000. Training on the conventional, best-practice approaches used in this field test using a duct blower can probably be obtained from the manufacturer for a fee and is also often provided at national energy conferences.

\subsection{ECONOMICS}

The economics of duct sealing, as with most conservation measures, are usually highly housespecific. For duct sealing, economics depend on many variables, such as the initial energy use of the house, fuel costs, the location and extent of duct leaks, the degree of duct sealing achieved, and the costs incurred in sealing the ducts in the house. Because of the large variability in energy savings measured in each house, as discussed in Sect. 7.1, house-specific economics were not investigated. Rather, we performed calculations for various groups of houses to provide some indication of the overall, average economic viability of the duct sealing performed.

Table 8.3 summarizes the potential economics of duct sealing for three groups of houses treated in the field test:

- all houses (representing sealing ducts in all homes encountered in a weatherization program),

- houses with some ducts outside the conditioned space of the house (representing sealing ducts just in those homes that might most benefit from this work), and 
Table 8.3. Average economics for the best-practice and aerosol approaches

\begin{tabular}{|c|c|c|c|c|c|c|c|c|}
\hline \multirow[b]{3}{*}{ House type } & \multirow{2}{*}{\multicolumn{2}{|c|}{$\begin{array}{l}\text { Energy } \\
\text { savings }\end{array}$}} & \multicolumn{3}{|c|}{$\begin{array}{c}\text { Conventional, best-practice } \\
\text { approach }\end{array}$} & \multicolumn{3}{|c|}{ Aerosol-spray technology } \\
\hline & & & \multirow{2}{*}{$\begin{array}{l}\text { Installation } \\
\text { costs } \\
(\$)\end{array}$} & \multirow{2}{*}{$\begin{array}{c}\text { Simple- } \\
\text { payback } \\
\text { period }\end{array}$} & \multirow{2}{*}{$\begin{array}{l}\text { Savings-to- } \\
\text { investment } \\
\text { ratio }\end{array}$} & \multirow{2}{*}{$\begin{array}{c}\text { Installation } \\
\text { costs } \\
(\$)\end{array}$} & \multirow{2}{*}{$\begin{array}{l}\text { Simple- } \\
\text { payback } \\
\text { period }\end{array}$} & \multirow{2}{*}{$\begin{array}{l}\text { Savings-to- } \\
\text { investment } \\
\text { ratio }\end{array}$} \\
\hline & Therms & $\$$ & & & & & & \\
\hline All houses & 65 & 47 & 260 & 5.5 & 2.1 & 189 & 4.0 & 2.9 \\
\hline $\begin{array}{l}\text { Some ducts } \\
\text { outside }\end{array}$ & 107 & 77 & 260 & 3.4 & 3.4 & 189 & 2.5 & 4.7 \\
\hline $\begin{array}{l}\text { Ducts just in } \\
\text { basement }\end{array}$ & 23 & 17 & 260 & 15.3 & 0.8 & 189 & 11.1 & 1.0 \\
\hline
\end{tabular}

- houses with all ducts in the basement (representing a class of homes with perhaps the least potential for energy savings from duct sealing).

These three groups are consistent with groups as defined in Table 7.1.

The energy savings for each group were assumed to be equal to the energy savings measured in the field test and reported in Table 7.1. These savings were converted into cost savings by assuming $\$ 0.72$ per therm, which was the average cost for natural gas in the year 2000 . The same energy savings were assumed for sealing ducts using the aerosol-spray technology and the conventional, best-practice approach because no difference between methods was measured in the field test houses (see Sect. 7.2). However, the larger reductions in air leakage measured in the homes using the aerosol-spray technology would be expected to translate into higher energy savings compared with the homes using just the best-practice approach.

Installation costs for the conventional, best-practice approach were estimated by assuming $330 \mathrm{~min}$ (5.5 hours) of labor to make repairs (based on Table 8.1); 1.5 hours of labor to set up, tear down, and perform diagnostics; $\$ 50$ in material costs (based on Table 8.1); and a labor rate of $\$ 30$ per hour. The total estimated cost of $\$ 260$ is consistent with an average cost of \$293 (\$41 for materials and \$252 for labor) reported by Jump, Walker, and Modera (1996) in another field test. The total estimated crew-time of 7 hours is also consistent with an average crew-time of 10.3 hours reported by Modera et al. (1996) for conventional duct sealing in a Florida field test.

Similarly, installation costs for using the aerosol-spray technology were estimated assuming 98 min (1.6 hours) of labor to operate the aerosol-spray equipment and manually seal major leaks during operation of the equipment (see Sect. 8.1); 3 hours of labor to set up, tear down, and perform diagnostics; $\$ 50$ in material costs (see Sect. 8.1); and a labor rate of $\$ 30$ per hour. Costs to purchase necessary equipment were not included for either method. The total estimated crew-time of 4.6 hours is consistent with an average crew-time of 4.4 hours reported by Modera et al. (1996) to perform aerosol-spray duct sealing in another field test once crews became familiar with the duct-sealing equipment.

Finally, Table 8.3 provides both the simple-payback period and the savings-to-investment ratio (SIR). The SIR was calculated following DOE Weatherization Assistance Program guidelines. A uniform present value of 11.59 was used in the SIR calculations based on a discount rate of $3.4 \%$ for the year 
2000 and assuming a 15-year life, natural gas as the fuel, and a U.S. average (Fuller and Boyles 2000).

The results shown in Table 8.3 confirm that, on average, duct sealing as performed in the field test can be a very economical energy conservation measure if the assumptions made in the calculations are reasonable. For example, if average costs for sealing ducts with the aerosol-spray technology are $\$ 1,009$, as reported by Kallett et al. (2000) for a utility-based program in California, then the duct sealing performed with this technique would not be economical. The economics are especially favorable in houses that can most benefit from duct sealing (e.g., houses with ducts located outside the conditioned space rather than in a conditioned basement), suggesting that weatherization programs might want to target the types of houses to receive duct-sealing measures. Higher SIRs and lower simple-payback periods result for the aerosol-spray technology because of its lower estimated installation cost, even without considering its potentially higher energy savings.

\subsection{MANUAL REPAIR DESCRIPTIONS}

When the aerosol-spray technology is used, major leaks such as disconnected ducts must still be sealed manually. Manual sealing is also recommended for larger holes to speed the aerosol-sealing process. Descriptions of the manual duct sealing performed in the 39 aerosol houses, as recorded by the crews, shed some light on the type and extent of manual duct sealing required. These descriptions are summarized as follows:

- Little manual duct sealing was performed in 9 homes.

- Supply and return boots were reported as having been sealed in 9 houses, although this repair was probably performed routinely in all houses. Manual sealing is recommended in this case because the solid foam used to seal off the supply and return registers during the aerosol sealing process are placed inside the ducts, preventing these leakage sites from being sealed automatically.

- Major leaks were sealed in the returns of 8 houses. This task included redesigning the return, replacing a missing "pan" in a panned floor joist return, installing an end-cap at the end of a panned floor joist return (2 houses), and patching a large hole in the return (4 houses).

- Returns were sealed manually in 22 homes. Manual sealing is recommended in using the aerosol approach when the length of the return is short and the leaks are accessible because of the time required to connect the aerosol equipment to a second location (from the supply trunk to the return).

- Major work was performed on the supply ducts of 10 houses. This work included reconnecting a supply line (3 houses), installing rigid duct inside a torn flex duct, and sealing holes and performing other sealing work (6 houses).

The manual duct repairs performed in the 37 best-practice houses were also examined to identify major repairs that would have been performed manually if the aerosol-spray approach had been used. These included

- installing a new 16-in. elbow in a return duct that had rusted out,

- replacing or rebuilding a panned floor joist return that had disintegrated (3 houses),

- rebuilding a return that had used open wall cavities,

- reconnecting a return duct to the return register,

- installing a block at the end of a panned floor joist return,

- sealing off a return duct that was open to an unused room in a garage,

- resupporting a collapsed supply trunk and reconnecting supply lines in the process (2 houses), 
- installing supply boots on a system that had none, and

- sealing a hole where a supply duct used to be.

One advantage of the aerosol-spray technology is that it has the potential for sealing leaks that cannot be accessed for manual repair. Crews reported a number of these cases in the best-practice houses:

- ducts in dropped or finished ceilings (2 houses),

- ducts in interior wall cavities or chaseways (4 houses),

- ducts with asbestos tape on the joints (2 houses),

- inaccessible return (4 houses), and

- $\quad$ inaccessible supply duct (3 houses).

\subsection{SAFETY}

Safety concerns with backdrafting, carbon monoxide production, and other problems with combustion appliances were assessed before and after duct repair using the normal procedures employed by each agency. Some such problems were found by the agencies as the houses were being selected for the study; in these cases the problems were either corrected or the houses were not included in the study.

During the pre-duct-sealing diagnostics, five houses were found to have safety problems which were subsequently corrected. No safety problems were created because of the duct-sealing work performed under this study. 


\section{WEATHERIZATION AGENCY INPUT}

Weatherization staff from four of the five agencies participating in the field test provided input on the performance of the aerosol-spray equipment and advanced diagnostic procedures and recommendations for their use within the Weatherization Assistance Program through the questionnaire provided in Appendix B. Agencies responded to this questionnaire before knowing what the field test results were.

The purpose of the questionnaire was to gain insight into how advanced duct-sealing technologies should be incorporated into the Weatherization Assistance Program, if at all. Putting this issue into its proper context, one agency pointed out that "duct sealing is just one of dozens of different tasks performed under weatherization and should not be singled out as more important or requiring so much more resources than other measures."

\subsection{AEROSOL-SPRAY TECHNOLOGY}

In general, all four responding weatherization agencies were impressed with the aerosol-spray technology, its hardware, and the duct sealing that could be achieved from its use. One agency summarized this by stating: "I feel it is far superior to the standard approach." Although impressed, the agencies were also quick to point out that the aerosol-spray method is not a practical tool for all applications, such as simple, small, and accessible duct systems that could be sealed easily by hand.

Without knowing the field test results, two agencies felt that the aerosol-spray technology sealed ducts better and achieved better reductions in leakage than use of best-practice approaches alone. One agency stated: "It does a fantastic job! There is simply no way that a crew of three could seal ducts as well or as efficiently as this machine does." One agency pointed out that the aerosol-spray technology is able to seal otherwise inaccessible leaks, can be used to seal smaller holes that cannot be sealed cost-effectively by hand, and can seal wrapped (i.e., insulated) ductwork. Faster sealing times and, hence, reduced labor were mentioned by two agencies, although one of these agencies recognized that the aerosol-spray technique is not always the fastest (e.g., with small, accessible systems that may be easier to do by hand).

Three agencies cited the computerized documentation of leakage and a printout documenting the reduction achieved as other advantages of the aerosol-spray technology, since this documentation can be given to clients, although one of these agencies felt that clients don't know ducts are being sealed and don't care. Three agencies also mentioned lower material costs as another benefit offered by the aerosol-spray technology. Two agencies said that the aerosol-spray technology is cleaner and less messy. Other benefits mentioned by the agencies are that the aerosol-spray equipment serves as a duct blower as well, charts progress as it seals, and allows one to find bigger leaks to seal by hand more easily by feeling for air flow while the sealing process is under way.

The primary problem encountered in using the aerosol-spray technology in the field test was the software program used to operate the machine and collect data. As explained in Sect. 2, the software program was designed for private-sector HVAC contractors to market, diagnose, and perform duct sealing using the aerosol-spray technology. In addition to having "windows" that measure the preretrofit duct leakage, control the duct-sealing, measure the post-retrofit duct leakage, and transfer collected data, the program has many other windows that are used to collect household information and perform a variety of duct and safety diagnostics. For the field test, only the first four windows mentioned were used, as well as one other to collect pre-retrofit dominant duct leakage data. Nevertheless, data still had to be entered in some of these other windows in order for the program to 
work. In addition, to collect all of the data desired (e.g., to measure total and outside duct leakages based on supply and return duct pressures instead of just one measurement of duct leakage), the program had to be run multiple times and in ways not intended by the software designers.

All four weatherization agencies responding to the questionnaire reported difficulty in learning how to use the software. Entering unnecessary data was tedious and slowed work progress. The agencies recognized that the software and its related diagnostics required too much information in its present form because it is designed for private-sector HVAC work rather than for use in the Weatherization Assistance Program. Two agencies reported that using the software did become easier after the first few houses were sealed and initial problems were resolved. For use in the Weatherization Assistance Program, these same two agencies recommended that the software be considerably retooled and simplified. They recommended that the new software focus just on pre- and post-retrofit duct leakage testing and on controlling the sealing operation because other information is routinely collected during initial weatherization audits.

Two agencies generally felt that the hardware worked very well. One agency said that the "equipment is well designed and did more than an adequate job on all the ducts we used it on." The agencies did identify some possible problems with the hardware:

- One agency said that the size of the equipment could have some impacts on program implementation. The equipment is large and requires a lot of storage space in the shop and especially on the truck. This can pose practical problems in light of the other equipment and weatherization materials that must be hauled to the job site.

- One agency found that pulling the furnace to connect the equipment to the ducts is not as hard as first thought, although it felt this step could still be time consuming and can lead to finding problems that then need to be fixed (e.g., improper wiring).

- One agency reported that setup times were initially $90 \mathrm{~min}$, but dropped to $30 \mathrm{~min}$ after the crew became more familiar with the equipment. Another agency, though, reported typical setup times of two hours.

- Two agencies identified the need to keep the furnace off while sealing the ducts and the need to pressurize the house to 5 to $10 \mathrm{~Pa}$ while sealing to prevent the aerosol-spray from entering the house as problems. This reduced indoor temperatures considerably on cold days in some houses, which some occupants found objectionable.

- Other problems identified by one or another agency included finding electrical connections in houses with marginal electrical systems, the need for numerous electrical cords to run the equipment, the time needed for equipment to cool down, and the need for a portable computer, which increases equipment costs.

Three of the agencies felt that the aerosol-spray technology would be a useful tool for use in their agency and would recommend its adoption within the Weatherization Assistance Program. These agencies felt that a primary obstacle to overcome would be the cost of the equipment needed for each agency and crew (based on their perception of this cost). Two agencies recommended using regular weatherization crews rather than a special crew to implement the technology - perhaps using one trained person per crew. Another thought a specialized crew would be preferable, so that a house could be tested and sealed, if necessary, all in one day. Three weatherization agencies felt that other weatherization work could be performed while the duct sealing was performed, with the possible exception of furnace work and safety diagnostics. Moreover, one agency believed that crew members performing the duct sealing would be free to do other work while the ducts were being sealed because the aerosol-spray technology is fairly automated once the equipment is set up; this would improve efficiency considerably. 
Another agency, however, disagreed. It stated: "Most technicians that work in the programs do not have a very high skill level and would need a good understanding of whole house pressure diagnostics in order to be successful in operating the machine. . . A well-trained weatherization technician can achieve reasonable duct-sealing results with a blower door and pressure pan; therefore, I don't believe it would be a cost savings or time savings to use the machine." This agency felt that use of the aerosol equipment still requires manual sealing because big holes cannot be automatically sealed, that the equipment would not be useful for mobile homes (the bulk of the agency's work), and that its use would require a change in the flow of other weatherization work in the house because a special duct-sealing crew would be needed.

Three agencies recognized that extended training would be required to implement the technology and that the training could be crew-specific depending on individual backgrounds in computer use and other diagnostic techniques. One agency felt that the aerosol-spray approach is sufficiently complex that it could not be turned over to a crew member with lower skill levels - that it does require some competence and skill to operate, especially on the computer and software side. The training recommended by these three agencies was similar to that provided for the field test (see Sect. 3.3), which was sufficient to implement the technology in this project. They recommended classroom training followed immediately by a field training component; suggestions ranged from three days in the classroom and two days in the field to as much as one week in the classroom and one week in the field. These three agencies also suggested that this training be followed by a field-monitoring component on the first several production houses sealed by the newly trained crews. One agency recommended smaller class sizes with no more than three to five people per machine and emphasized the importance of thorough training on the software used to operate the machine.

\subsection{BEST-PRACTICE TECHNOLOGY}

Two weatherization agencies felt that measuring duct leakages with a duct blower supplemented the information they normally collect using pressure pans. They felt that the duct blower measurements

- gave them a much more comprehensive look at the overall condition of the duct system,

- gave good information on whether ducts need to be sealed,

- gave them feedback on whether ducts were sealed sufficiently, and

- improved crew understanding of duct leakage, impact on the house and heating system, and whether supply or return ducts needed more attention.

These two agencies felt that these measurements are worth the time and money spent, especially when combined with pressure pan readings, and recommended that they become a more regular part of the Weatherization Assistance Program. Because duct blower measurements are somewhat timeconsuming, one agency recommended that field measurements focus on the most important elements to minimize the time to make the measurements and that they be used only when practical. For example, the measurement may not be needed in a mobile home if the belly is going to be blown anyway. One agency thought that training of crews may not be very difficult because the concepts for using a duct blower are similar to those for a blower door. Classroom, field training, and follow-up components were again recommended. Recommended training times ranged from three days to two weeks.

One agency disagreed, however. This agency felt that a well-trained technician can do cost-effective work with a visual inspection, a good procedure, a blower door, and a pressure pan. They believed that a crew can get a lot of work done in the time it takes to make duct leakage measurements. Because these measurements do not help indicate where the leaks are, the agency did not think the 
measurements help with production mode sealing. The agency also thought that a duct blower is too expensive to have on every crew truck.

Two agencies recommended measuring the dominant duct leakage in the house during productionmode duct sealing because the time and cost of doing the measurement is minimal, the equipment is on hand, it does not interfere with weatherization work, and the information is useful in telling crews which system (supply or return) to concentrate on and when the ducts have been sealed sufficiently. A third agency with two responders was split on this subject, with the detractor feeling that measurement of dominant duct leakage does not tell a crew member where the leaks are and that the measurement is an unnecessary expense, especially if the ducts were going to be sealed tightly anyway (a point mentioned even by one of the proponents of this measure). 


\section{CONCLUSIONS AND RECOMMENDATIONS}

\subsection{CONCLUSIONS}

Duct leakage problems in homes eligible for the Weatherization Assistance Program are prevalent and perhaps worse than in the general population of homes. The average duct leakage of 500-600 $\mathrm{cfm} 25$ measured in the field test homes from five weatherization agencies spread across the northern part of the United States is larger than the average leakages found in many other studies of non-lowincome homes.

Although both the best-practice and the aerosol-spray technologies are successful at sealing leaks in ducts, the aerosol-spray technology combined with manual sealing of large leaks is more effective at sealing duct leaks by $50 \%$ or more compared with just the best-practice approach. Between 60 and $70 \%$ of the duct leakage, on average, could be sealed when the aerosol-spray technology was used to seal small leaks while major leaks were sealed manually. The average reduction in duct leakage was only about 40 to $50 \%$ when manual methods alone were employed. Duct leakage reductions were also more consistent and more predictable in the houses receiving the aerosol-spray treatment than in those receiving best-practice duct sealing alone. Pressure pan readings further support these findings.

An average savings of 5\% was measured in space-heating energy use from the duct sealing performed in this field test. However, in homes where the ducts were clearly located outside the conditioned space of the home (i.e., in insulated attics or carports) rather than inside the home or in spaces partially connected to the conditioned space of the house (i.e., basements and uninsulated crawlspaces), the measured space-heating energy savings is nearly twice the average value, or about $9 \%$. Scatter in the energy usage data are too great to measure the difference in energy savings between the two duct-sealing methods. However, the larger air leakage reductions measured in the homes using the aerosol-spray technology would be expected to translate into higher energy savings compared with the homes using just the best-practice approach.

The aerosol-spray technology has the potential to reduce labor time associated with just sealing the ducts by $70 \%$, or almost 4 crew-hours. The average time to seal ducts using the aerosol-spray technology was 98 minutes, and it is possible that one person could operate the equipment and perform the necessary manual sealing during this time period. The best-practice approach took an average of $147 \mathrm{~min}$ and required $330 \mathrm{crew}$-minutes. The material costs associated with both methods are about the same. Setup, tear-down, and diagnostic times must also be considered in determining the overall or total labor costs associated with a particular duct-sealing method. These times could not be determined from the field test. Although times to perform these tasks are probably greater for the aerosol technology than for the conventional, best-practice technology, the difference is not likely to offset the additional 4 crew-hours needed to seal the ducts under the best-practice approach.

Three of the four responding agencies felt that the aerosol-spray technology was superior to the bestpractice approach, although they recognized that it was not the correct tool for all applications. Implementation issues raised by the agencies included equipment costs, equipment size, and the existing software used to operate the equipment. The agencies also generally saw some value in making duct leakage measurements in addition to just pressure pan readings as part of the bestpractice approach, although a strong consensus was not reached. 


\subsection{RECOMMENDATIONS}

Duct sealing using the best available method should continue to be a recommended weatherization measure. Continued training on conventional approaches is needed to achieve better duct leakage reductions and lower post-retrofit duct-leakage rates than those observed in this field test. Postretrofit duct leakages greater than $600 \mathrm{cfm} 25$, as observed in this field test, indicate that major leaks are not being identified and sealed. Training should also promote more consistent results among agencies and perhaps faster installation times.

Based on the benefits observed in this field test (better and more consistent air leakage reductions and shorter repair times compared with best-practice technologies alone), as well as the positive input received from the participating weatherization agencies, we recommend further study to encourage and promote use of the aerosol-spray technology within the Weatherization Assistance Program. The aerosol-spray technology could make duct sealing a more viable measure within the Weatherization Assistance Program by improving the cost-effectiveness of the measure and keeping total weatherization costs below program guidelines.

We recommend a pilot test of the aerosol-spray technology in conjunction with full-scale weatherization to develop approaches for integrating this technology with other energy conservation measures and minimizing impacts on weatherization agency logistics. Implementation approaches that allow aerosol-spray duct sealing to be performed while other measures such as air sealing and side-wall insulation are installed must be established. The potential time-saving benefits of the automated aerosol-spray technology, which could allow crews to work on other tasks while the sealing takes place, need to be verified. The need for speciality crews to perform duct sealing because of required skill levels and considerations of equipment cost and hauling must be determined. The five agencies used in this field test should be considered for this follow-up activity because they are already familiar with the technology and could provide this feedback in the quickest time for the least cost.

In order to allow or improve adoption of the aerosol-spray technology within the Weatherization Assistance Program, four issues identified during the field test and raised by the participating weatherization agencies need to be addressed. These issues are discussed below.

- Equipment cost and franchise structure. The current costs associated with the equipment and Aeroseal's franchise approach to distributing the technology (see Sect. 8.2) are likely to prohibit widespread adoption within the Weatherization Assistance Program. At present, each weatherization agency across the country would face a cost of $\$ 20,000$ plus royalty fees in order to become a separate franchisee. The requirement to provide Aeroseal with data on each house might breach confidentiality guidelines that weatherization agencies must adhere to. In addition, the need to meet monthly quotas imposed by Aeroseal may overly restrict and dictate the work performed by weatherization agencies.

DOE should discuss with Aeroseal how equipment and franchise costs could be reduced and the franchise approach and requirements altered to speed adoption of this technology in the Weatherization Assistance Program. Weatherization agencies primarily want access to the equipment, software, and training without other restrictive requirements so that they can implement the technology into their unique programs in the best possible way. The magnitude of purchases possible throughout the weatherization program network would suggest bulk purchases that could considerably reduce costs. DOE should consider state, regional, and national agreements to move the technology into programs. 
In the meantime, DOE should investigate to what extent it is bound by Aeroseal's exclusive licensing agreement, since DOE and the U.S. government helped fund the initial development of the technology at one of the national laboratories and now want to use it. DOE should also determine how much of the equipment and software development was performed with government funding and how much was performed by Aeroseal itself.

- Software. The software used in the field test to control the equipment was developed by Aeroseal for use by HVAC contractors in its franchise approach. This software was designed for two separate visits by the HVAC contractor (one to market the job and the second to seal the house), collected considerable house and occupant information, performed a variety of diagnostics, and facilitated the transfer of data collected on each house to Aeroseal as required under the franchise agreement. The field test found that this software was unwieldy. For use within the Weatherization Assistance Program, agency staff would need a considerably scaleddown and simplified version of this software that measures duct leakage before and after duct sealing and operates the equipment during the sealing process. DOE should discuss the development of such software with Aeroseal.

- Safety. Aeroseal states that aerosol sealing "has been tested by Underwriters Laboratories, Inc. (UL) and the Indoor Environment program at Lawrence Berkeley National Laboratory." However, DOE should further investigate and document the safety of this product and its components before recommending full-scale implementation within the weatherization program. In basement houses that have especially leaky ducts, for example, a fog of aerosol spray often develops in the basement at the commencement of duct sealing. Although Aeroseal recommends use of a scrubber fan (a box fan with a filter on the suction side of the fan) and a dust mask to mitigate the danger that workers and occupants could inhale the sealant or solvent suspended in this fog, the need for such mitigation and the effectiveness of the recommendations should be determined. In addition, the effect of the aerosol spray on animals (especially exotic pets that are sometimes found in homes) or occupants with poor health should be investigated.

- Training. The training provided to the weatherization crews for this field test of the aerosolspray technology consisted of one day in the classroom and two days in the field sealing two houses. This training was sufficient to implement the new technology successfully, although more training on the software would have improved the agencies' performances. However, the agencies used in the field test were experienced in basic duct diagnostics (primarily pressure pans) and manual duct sealing and, in some cases, were state trainers themselves. As less experienced crews are trained in the new technology, the training program should be more extensive and should include a field monitoring component to provide immediate feedback to the newly trained crews.

Finally, application testing of the aerosol-spray technology in mobile homes is recommended. The Weatherization Assistance Program is serving more and more mobile homes each year, and mobile homes are the predominant house type served by many weatherization agencies. The aerosol-spray technology has been tested in mobile homes only on a very limited basis, and this field test addressed application of this technology to site-built, single-family homes only. 



\section{REFERENCES}

ASHRAE (American Society of Heating, Refrigerating, and Air-Conditioning Engineers). 2001. Method of Test for Determining the Design and Seasonal Efficiencies of Residential Thermal Distribution Systems. ASHRAE Standard 152P (Proposed) — Draft 01/1. Atlanta: American Society of Heating, Refrigerating, and Air-Conditioning Engineers.

Bohac, David, Karen Linner, and Tim Dunsworth. 1996. "Weatherization Program Short-Term Evaluation Methods." Pp. 3.23-3.31 in Proceedings of the 1996 ACEEE Summer Study on Energy Efficiency in Buildings, vol. 3. Washington, D.C.: American Council for an EnergyEfficient Economy.

Cummings, J. B., J. J. Tooley, N. Moyer, and R. Dunsmore. 1990. "Impacts of Duct Leakage on Infiltration Rates, Space Conditioning Energy Use, and Peak Electrical Demand in Florida Houses." Pp. 9.65-9.76 in Proceedings of the ACEEE 1990 Summer Study on Energy Efficiency in Buildings, vol. 9. Washington, D.C.: American Council for an Energy-Efficient Economy.

Davis, B., David Baylon, and Aaron Houseknecht. 1998. "Developing a Market-Based Utility Duct Sealing Program.” Pp. 2.21-2.31 in Proceedings of the ACEEE 1998 Summer Study on Energy Efficiency in Buildings, vol. 2. Washington, D.C.: American Council for an Energy-Efficient Economy.

Davis, B. E., and M. Robinson. 1993. "Using the Pressure Pan Technique to Prioritize Duct Sealing Efforts: A Study of 18 Arkansas Homes." Energy and Buildings 20:57-63.

Fuller, Sieglinde K., and Amy S. Boyles. 2000. Energy Pride Indices and Discount Factors for Lifecycle Cost Analysis - April 2000: Annual Supplement to NIST Handbook 135 and NBS Special Publication 709. NISTIR 85-3273-15 (Rev. 4/00). Washington, D.C.: U.S. Department of Commerce, April.

Jump, David A., Iain S. Walker, and Mark P. Modera. 1996. "Field Measurements of Efficiency and Duct Retrofit Effectiveness in Residential Forced Air Distribution Systems.” Pp. 1.147- 1.155 in Proceedings of the ACEEE 1996 Summer Study on Energy Efficiency in Buildings, vol. 1. Washington, D.C.: American Council for an Energy-Efficient Economy.

Kallett, Rick, Ed Hamzawi, Craig Sherman, and Janis Erickson. 2000. "SMUD's New Residential Duct-Improvement Program Using an Aerosol-Based Sealant.” Pp. 2.163-2.174 in Proceedings of the ACEEE 2000 Summer Study on Energy Efficiency in Buildings, vol. 2. Washington, D.C.: American Council for an Energy-Efficient Economy.

Kinert, R. C., D. C. Engel, J. P. Proctor, and R. K. Pernick. 1992. "The PG\&E Model Energy Communities Program: Offsetting Localized T\&D Expenditures with Targeted OSM." Pp. 5.131-5.136 in Proceedings of the ACEEE 1992 Summer Study on Energy Efficiency in Buildings, vol. 5. Washington, D.C.: American Council for an Energy-Efficient Economy. 
Kolb, James O., and Mark P. Ternes. 1995. "Investigation of Air Distribution System Deficiencies and Repair Benefits in Phoenix, Arizona." Pp. 379-87 in Proceedings of the Thermal Performance of the Exterior Envelopes of Buildings VI, Clearwater Beach, Fla., December 4-8. Atlanta: ASHRAE Special Publication.

Lerman, David. 1998. "Getting Our Ducts in a Row: Evaluation of the Tacoma Duct Sealing Program." Pp. 2.115-2.126 in Proceedings of the ACEEE 1998 Summer Study on Energy Efficiency in Buildings, vol. 2. Washington, D.C.: American Council for an Energy-Efficient Economy.

Minnesota Office of Low-Income Energy Programs. 1998. User's Manual for Achieved Savings Assessment Program (ASAP), Featuring DESLog. St. Paul, Minn., September.

Modera, Mark P., Darryl Dickerhoff, Oddbjorn Nilssen, Holly Duquette, and Jan Geyselaers. 1996. "Residential Field Testing of an Aerosol-Based Technology for Sealing Ductwork." Pp. 1.169-1.175 in Proceedings of the ACEEE 1996 Summer Study on Energy Efficiency in Buildings, vol. 1. Washington, D.C.: American Council for an Energy-Efficient Economy.

Nadel, Steven, Leo Rainer, Michael Shepard, Margaret Suozzo, and Jennifer Thorne.1998. Emerging Energy-Savings Technologies and Practices for the Buildings Sector. Washington, D.C.: American Council for an Energy-Efficient Economy, December.

Vigil, F. 1993. “Duke Power's Success.” Home Energy 10, no. 5: 45-47. 


\section{APPENDIX A}

\section{FIELD DATA COLLECTION FORMS AND PROCEDURES}

Data were collected before and after duct sealing using the data collection forms and procedures provided in this appendix. Information collected included house air leakage, pressure pan measurements, house and dominant duct leakages, combustion safety, duct operating pressures, and duct leakage. The first set of forms and procedures provided here was used for the houses receiving conventional, best-practice duct sealing and the second set for houses receiving aerosol-spray duct sealing. The two sets of forms and procedures collected the same information. The forms and procedures are slightly different because a pressure meter and duct blower were used to collect the house and dominant duct leakage data and the leakage rates of the ducts in the conventional, bestpractice houses, whereas in the aerosol-spray houses the aerosol-spray equipment itself was used for this purpose. 



\section{FIELD TEST DATA COLLECTION FORM: CONVENTIONALLY TREATED HOMES}

Revised: December 30, 1999

Date:

Arrival time:

House code:

House address:

(or occupant name)

\section{HOUSE AIR LEAKAGE MEASUREMENTS}

Install the blower door and set up the house to make a blower-door measurement:

$\square$ open interior doors

$\square$ close exterior doors, windows, and doors to semi-conditioned areas

$\square$ close or seal pet doors

$\square$ close attic accesses

$\square$ close fireplace dampers

$\square$ turn off the space-heating system, water heater (to pilot), and exhaust fans (bathroom, kitchen, etc.)

$\square$ turn off powered attic fans

Depressurize the house to $50 \mathrm{~Pa}$ (house pressure WRT outside is -50 Pa) and measure the house air leakage. Make two measurements in houses with basements:

- the first measurement with the basement door to the house open and all basement windows, basement doors to the outside, etc. closed

- the second measurement with the basement door to the house closed (basement windows still closed)

\begin{tabular}{|c|c|c|c|c|}
\hline & \multicolumn{2}{|c|}{ PRE } & \multicolumn{2}{|c|}{ POST } \\
\hline & Test 1 & Test $2^{a}$ & Test 1 & Test $2^{a}$ \\
\hline \multicolumn{5}{|l|}{ Time } \\
\hline $\begin{array}{l}\text { House pressure } \\
\text { WRT outside }\end{array}$ & $\mathrm{Pa}$ & $\mathrm{Pa}$ & $\mathrm{Pa}$ & $\mathrm{Pa}$ \\
\hline \multicolumn{5}{|l|}{ Ring $^{\mathrm{b}}$} \\
\hline $\begin{array}{l}\text { Fan pressure } \\
\text { WRT house }\end{array}$ & $\mathrm{Pa}$ & $\mathrm{Pa}$ & $\mathrm{Pa}$ & $\mathrm{Pa}$ \\
\hline Flow rate & $\mathrm{cfm}$ & $\mathrm{cfm}$ & $\mathrm{cfm}$ & $\mathrm{cfm}$ \\
\hline Time & & & & \\
\hline
\end{tabular}

Notes: ${ }^{a}$ Use this second column only in houses with a basement to record measurements with the basement door closed.

${ }^{\mathrm{b}} \underline{\mathrm{O}}$ - Open, $\underline{\mathrm{A}}$ - Ring A, $\underline{\mathrm{B}}$ - Ring B, $\underline{\mathrm{C}}$ - Ring C 


\section{PRESSURE PAN MEASUREMENTS}

Set-up the house to make pressure pan readings:

$\square$ remove the filter from the duct system

$\square$ make sure all duct registers, grills, and dampers are fully open

$\square$ temporarily seal outside combustion air inlets or ventilation system connections which are hard ducted into the duct system

$\square$ seal supply registers in semi-conditioned spaces such as garages, etc.

$\square$ in basement houses, close the basement door to the house, open a window in the basement, and seal all basement supply and return registers

$\square$ in crawl space houses, open crawl space vents

Use the blower door to depressurize the house to $50 \mathrm{~Pa}$ (house pressure WRT outside is $-50 \mathrm{~Pa}$ ) and record the actual value achieved in the table below.

\begin{tabular}{|l|r|r|}
\hline & PRE & POST \\
\hline House pressure WRT the outside & $\mathrm{Pa}$ & $\mathrm{Pa}$ \\
\hline
\end{tabular}

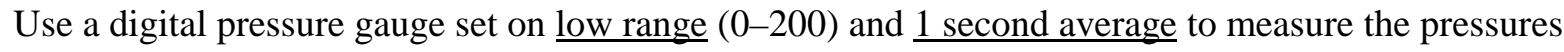
of zones with ducts located in them WRT the house. The hose measuring the zone pressure should typically be on the "input" port of the pressure gauge, and the "reference" port should be open to the house.

\begin{tabular}{|l|r|r|}
\hline \multirow{2}{*}{ Zones with ducts } & \multicolumn{2}{|c|}{ Zonal pressure WRT the house } \\
\cline { 2 - 4 } & PRE & POST \\
\hline Time & & $\mathrm{Pa}$ \\
\hline Attic & $\mathrm{Pa}$ & $\mathrm{Pa}$ \\
\hline Basement & $\mathrm{Pa}$ & $\mathrm{Pa}$ \\
\hline Crawl space & $\mathrm{Pa}$ & $\mathrm{Pa}$ \\
\hline Garage & $\mathrm{Pa}$ & $\mathrm{Pa}$ \\
\hline Other: & $\mathrm{Pa}$ & $\mathrm{Pa}$ \\
\hline Other: & & \\
\hline Time & & \\
\hline
\end{tabular}


Measure the pressure pan readings for all supply and return registers in the house, starting at the front door and working clockwise through the house. Use a digital pressure gauge set on low range (0-200) and 1 second average. The hose measuring the zone pressure should typically be on the "input" port of the pressure gauge, and the "reference" port should be open to the house.

\begin{tabular}{|c|c|c|c|c|}
\hline \multirow{2}{*}{$\begin{array}{l}\text { Register } \\
\text { number }\end{array}$} & \multirow[b]{2}{*}{ Supply or return } & \multirow[b]{2}{*}{ Zone } & \multicolumn{2}{|c|}{ Pressure WRT the house } \\
\hline & & & PRE & POST \\
\hline Time & & & & \\
\hline 1 & & & $\mathrm{~Pa}$ & $\mathrm{~Pa}$ \\
\hline 2 & & & $\mathrm{~Pa}$ & $\mathrm{~Pa}$ \\
\hline 3 & & & $\mathrm{~Pa}$ & $\mathrm{~Pa}$ \\
\hline 4 & & & $\mathrm{~Pa}$ & $\mathrm{~Pa}$ \\
\hline 5 & & & $\mathrm{~Pa}$ & $\mathrm{~Pa}$ \\
\hline 6 & & & $\mathrm{~Pa}$ & $\mathrm{~Pa}$ \\
\hline 7 & & & $\mathrm{~Pa}$ & $\mathrm{~Pa}$ \\
\hline 8 & & & $\mathrm{~Pa}$ & $\mathrm{~Pa}$ \\
\hline 9 & & & $\mathrm{~Pa}$ & $\mathrm{~Pa}$ \\
\hline 10 & & & $\mathrm{~Pa}$ & $\mathrm{~Pa}$ \\
\hline 11 & & & $\mathrm{~Pa}$ & $\mathrm{~Pa}$ \\
\hline 12 & & & $\mathrm{~Pa}$ & $\mathrm{~Pa}$ \\
\hline 13 & & & $\mathrm{~Pa}$ & $\mathrm{~Pa}$ \\
\hline 14 & & & $\mathrm{~Pa}$ & $\mathrm{~Pa}$ \\
\hline 15 & & & $\mathrm{~Pa}$ & $\mathrm{~Pa}$ \\
\hline 16 & & & $\mathrm{~Pa}$ & $\mathrm{~Pa}$ \\
\hline 17 & & & $\mathrm{~Pa}$ & $\mathrm{~Pa}$ \\
\hline 18 & & & $\mathrm{~Pa}$ & $\mathrm{~Pa}$ \\
\hline 19 & & & $\mathrm{~Pa}$ & $\mathrm{~Pa}$ \\
\hline Time & & & & \\
\hline
\end{tabular}




\section{HOUSE PRESSURE/DOMINANT DUCT LEAKAGE TESTS}

Set up the house to make house pressure/dominant duct leakage measurements:

seal off the blower door fan

reinstall the air filter

keep supply registers in semi-conditioned spaces such as garages, etc. sealed as done for the pressure pan measurements

$\square$ keep basement supply and return registers sealed as done for the pressure pan measurements

$\square$ in basement houses, keep the basement door to the house closed and a window in the basement opened as done for the pressure pan measurements

Measure the pressure of the main part of the house WRT a well-ventilated attic (preferred) or crawl space (both representing outside) with

- the air handler fan off

- the air handler fan on

- the air handler fan on and the return registers blocked $80 \%$

- the air handler fan off.

Make these measurements using a digital gauge set on low range $(0-200)$ and 5 second average. The hose (usually green) measuring the attic pressure should typically be on the "reference" port of the pressure gauge, and the "input" port should be open to the house. Make 10 consecutive

measurements at each condition and average the 10 readings (add them up and move the decimal one place to the left). Be careful to properly record the sign (+/-) of the pressure reading (negative should indicate supply leaks and positive return leaks) and to consider the sign in averaging the numbers.

NOTE:

The first and last measurements with the air handler fan off should be nearly the same since they are taken with the house set up under identical conditions. The third measurement, with the return registers blocked, should always be greater than the second measurement (e.g., 4 Pa compared with 2 $\mathrm{Pa},-1 \mathrm{~Pa}$ compared with $-3 \mathrm{~Pa}, 1 \mathrm{~Pa}$ compared with $-3 \mathrm{~Pa}$ ). 
PRE Measurements

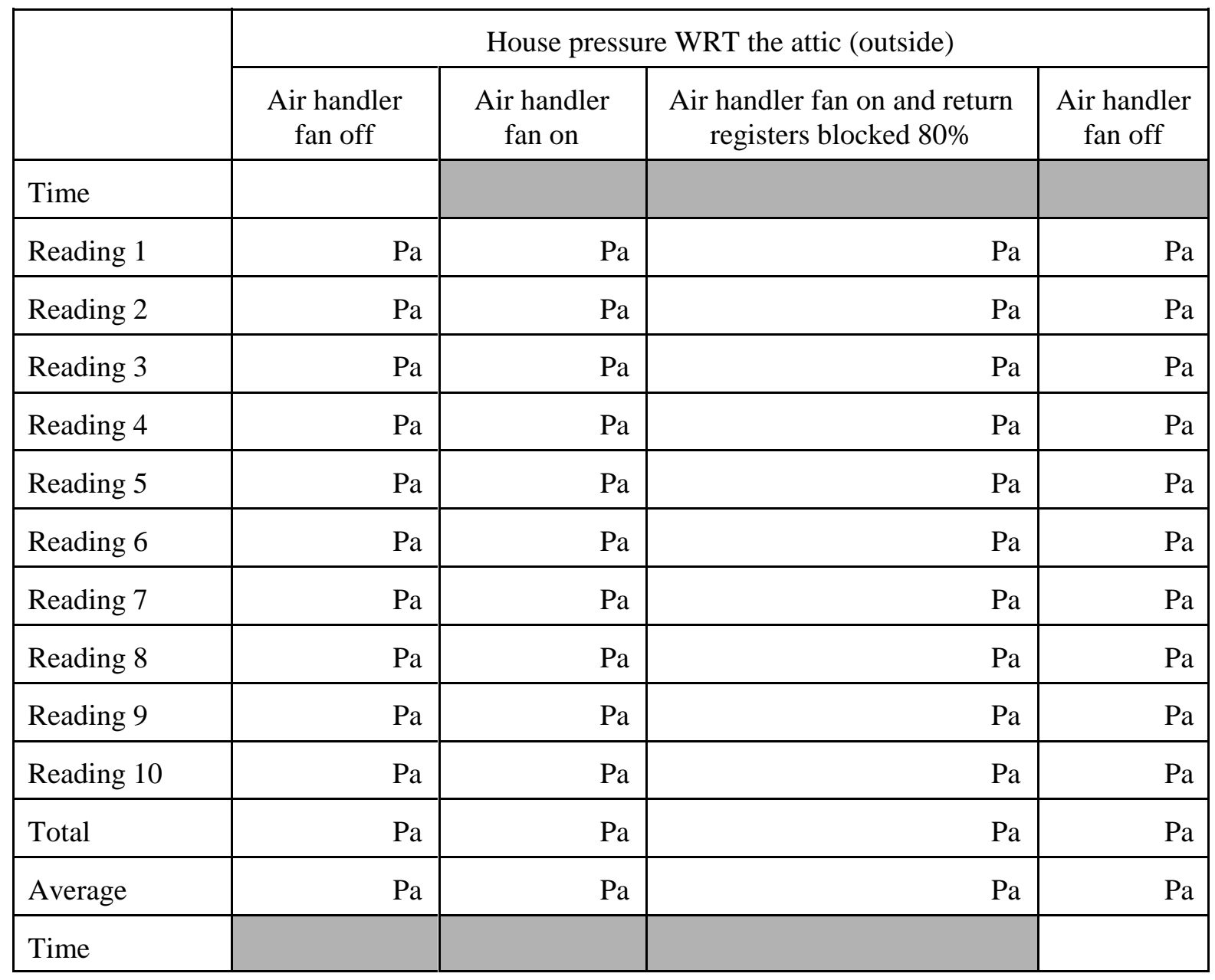


POST Measurements

\begin{tabular}{|l|r|r|r|r|}
\hline & \multicolumn{5}{|c|}{ House pressure WRT the attic (outside) } \\
\cline { 2 - 5 } & $\begin{array}{c}\text { Air handler } \\
\text { fan off }\end{array}$ & $\begin{array}{c}\text { Air handler } \\
\text { fan on }\end{array}$ & $\begin{array}{c}\text { Air handler fan on and return } \\
\text { registers blocked } 80 \%\end{array}$ & $\begin{array}{c}\text { Air handler } \\
\text { fan off }\end{array}$ \\
\hline Time & & & & $\mathrm{Pa}$ \\
\hline Reading 1 & $\mathrm{Pa}$ & $\mathrm{Pa}$ & $\mathrm{Pa}$ & $\mathrm{Pa}$ \\
\hline Reading 2 & $\mathrm{Pa}$ & $\mathrm{Pa}$ & $\mathrm{Pa}$ & $\mathrm{Pa}$ \\
\hline Reading 3 & $\mathrm{Pa}$ & $\mathrm{Pa}$ & $\mathrm{Pa}$ & $\mathrm{Pa}$ \\
\hline Reading 4 & $\mathrm{Pa}$ & $\mathrm{Pa}$ & $\mathrm{Pa}$ & $\mathrm{Pa}$ \\
\hline Reading 5 & $\mathrm{Pa}$ & $\mathrm{Pa}$ & $\mathrm{Pa}$ & $\mathrm{Pa}$ \\
\hline Reading 6 & $\mathrm{Pa}$ & $\mathrm{Pa}$ & $\mathrm{Pa}$ & $\mathrm{Pa}$ \\
\hline Reading 7 & $\mathrm{Pa}$ & $\mathrm{Pa}$ & $\mathrm{Pa}$ & $\mathrm{Pa}$ \\
\hline Reading 8 & $\mathrm{Pa}$ & $\mathrm{Pa}$ & $\mathrm{Pa}$ & $\mathrm{Pa}$ \\
\hline Reading 9 & $\mathrm{Pa}$ & $\mathrm{Pa}$ & $\mathrm{Pa}$ & $\mathrm{Pa}$ \\
\hline Reading 10 & $\mathrm{Pa}$ & $\mathrm{Pa}$ & $\mathrm{Pa}$ & $\mathrm{Pa}$ \\
\hline Total & $\mathrm{Pa}$ & $\mathrm{Pa}$ & & \\
\hline Average & $\mathrm{Pa}$ & $\mathrm{Pa}$ & & $\mathrm{Pa}$ \\
\hline Time & & & & $\mathrm{Pa}$ \\
\hline
\end{tabular}




\section{COMBUSTION SAFETY TESTS}

Set up the house to make combustion safety tests:

$\square$ unblock the return registers

$\square$ in basement houses, close the basement windows

$\square$ unseal any registers in the basement or in semi-conditioned spaces such as garages that may have been sealed to make pressure pan and dominant duct leakage measurements

In each combustion zone:

- Use procedures and approaches established by your agency to set up the house in a "worst case" scenario to test for combustion safety. Record the combustion appliances in the combustion zone as well as information on operation of the air handler fan, interior and basement door closures, and operation of exhaust fans to produce this worst case.

- Measure the pressure in the combustion zone WRT a well-ventilated attic (preferred) or crawl space (both representing outside) using a digital gauge set on low range (0-200) and 5 second average. The hose (usually green) measuring the attic pressure should typically be on the "reference" port of the pressure gauge, and the "input" port should be open to the combustion zone.

- Measure the draft of the combustion appliance and visually observe if spillage is occurring (if these are part of your normal inspection procedures).

- Based on your interpretation of these measurements and other measurements you have made, determine if there is a safety problem in this combustion zone.

- If a safety problem is indicated in the combustion zone after making the post safety inspections, perform any additional repairs necessary to mitigate the safety concern. Record the work performed and collect a final set of measurements. 


\section{Combustion Zone 1}

Combustion Appliances Present: $\quad \square$ Space-heating system

$\square$ Water-heating system

$\square$ Fireplace

$\square$ Gas dryer

$\square$ Other:

Worst Case Conditions:

\begin{tabular}{|l|l|l|l|}
\hline & PRE & POST & FINAL \\
\hline Time & & & \\
\hline Air handler fan (on, off) & & & \\
\hline Number of interior doors closed & & & \\
\hline Basement door (open, closed, NA) & & & \\
\hline Number of bathroom fans on & & & \\
\hline Kitchen range hood fan (on, off, NA) & & & \\
\hline Dryer (on, off, NA) & & & \\
\hline Other exhaust fan (on, off, NA): & & & \\
\hline
\end{tabular}

Combustion safety measurements:

\begin{tabular}{|l|r|r|r|}
\hline & PRE & POST & FINAL \\
\hline Combustion zone pressure WRT the attic (outside) & $\mathrm{Pa}$ & $\mathrm{Pa}$ & $\mathrm{Pa}$ \\
\hline Draft & in. w.c. & in. w.c. & in. w.c. \\
\hline Visual spillage (yes, no, NA) & & & \\
\hline Time & & & \\
\hline
\end{tabular}

Is there a combustion safety problem in this zone?
PRE: $\square$ Yes
POST: $\square$ Yes
FINAL: $\square$ Yes
$\square$ No
$\square$ No
$\square$ No

Repairs performed to mitigate safety problems found in this combustion zone following post inspections were: 


\section{Combustion Zone 2}

Combustion Appliances Present: $\square$ Space-heating system

$\square \quad$ Water-heating system

$\square$ Fireplace

$\square$ Gas dryer

$\square$ Other:

Worst Case Conditions:

\begin{tabular}{|l|l|l|l|}
\hline & PRE & POST & FINAL \\
\hline Time & & & \\
\hline Air handler fan (on, off) & & & \\
\hline Number of interior doors closed & & & \\
\hline Basement door (open, closed, NA) & & & \\
\hline Number of bathroom fans on & & & \\
\hline Kitchen range hood fan (on, off, NA) & & & \\
\hline Dryer (on, off, NA) & & & \\
\hline Other exhaust fan (on, off, NA): & & & \\
\hline
\end{tabular}

Combustion safety measurements:

\begin{tabular}{|l|r|r|r|}
\hline & \multicolumn{1}{|c|}{ PRE } & POST & FINAL \\
\hline Combustion zone pressure WRT the attic (outside) & $\mathrm{Pa}$ & $\mathrm{Pa}$ & $\mathrm{Pa}$ \\
\hline Draft & in. w.c. & in. w.c. & in. w.c. \\
\hline Visual spillage (yes, no, NA) & & & \\
\hline Time & & & \\
\hline
\end{tabular}

Is there a combustion safety problem in this zone?
PRE: $\square$ Yes
POST: $\square$ Yes
FINAL: $\square$ Yes
$\square$ No
$\square$ No
$\square$ No

Repairs performed to mitigate safety problems found in this combustion zone following post inspections were: 


\section{DUCT OPERATING PRESSURE MEASUREMENTS}

Drill a small hole in the supply plenum near the air handler fan and two small holes in the return plenum - one upstream and one downstream of the air filter.

Measure the pressures in the supply and return plenums WRT the room or the part of the house where the plenums are located with the air handler fan operating. Use a digital gauge set on low range (0-200) and 1 second average.

\begin{tabular}{|l|r|r|}
\hline & PRE & POST \\
\hline Time & & $\mathrm{Pa}$ \\
\hline Supply plenum pressure WRT the house & $\mathrm{Pa}$ & $\mathrm{Pa}$ \\
\hline $\begin{array}{l}\text { Return plenum pressure upstream of the } \\
\text { air filter WRT the house }\end{array}$ & $\mathrm{Pa}$ & \\
\hline $\begin{array}{l}\text { Return plenum pressure downstream of the } \\
\text { air filter WRT the house }\end{array}$ & & \\
\hline Time & & \\
\hline
\end{tabular}




\section{DUCT LEAKAGE MEASUREMENTS}

Install the duct blaster directly to the air handler or on the return grill closest to the air handler of sufficient size to make the connection.

Follow these guidelines in using the digital gauge to make the necessary measurements:

- The hose (usually green) measuring the outside (or well-ventilated attic) pressure should typically be on the "reference" port on the " $A$ " channel of the pressure gauge, and a blue hose should typically be connected to the "input" port of the "A" channel to measure the duct pressures.

- A red hose should typically be connected between the "input" port of channel "B" and the duct blaster, with the "reference" port of channel "B" left open to the house.

- The holes drilled previously in the return and supply ducts should be used, if possible, to make the required supply and return duct pressure measurements.

- Set the gauge on low range (0-200) and 1 second average while adjusting the fan speed to get the duct pressure to the desired value. Then switch over to a 5 second average to make the measurements.

- Set the digital gauge to the blower door setting with the proper ring selection in making the fan flow measurement (typically $8-0,1,2$, or 3 ).

Set up the house for the duct leakage measurements:

remove the air filter

$\square$ seal off all other supply and return registers with masking tape or ductmask

$\square$ unseal the blower door fan so that outside air can enter the house through the fan opening

$\square$ in basement houses, close the basement door to the house and open a basement window

Make two measurements of the total duct leakage using the duct blaster:

- Pressurize the supply ducts to 25 Pa WRT the outside using the duct blaster. Record the supply pressure actually achieved and the total duct leakage. Also measure the pressure in the return duct WRT the outside under this set-up.

- Pressurize the return ducts to 25 Pa WRT the outside using the duct blaster. Record the return pressure actually achieved and the total duct leakage. Also measure the pressure in the supply duct WRT the outside under this set-up. 
Pressurize the house to $25 \mathrm{~Pa}$ using the blower door. Make two measurements of the duct leakage to outside using the duct blaster:

- Pressurize the supply ducts to 25 Pa WRT the outside using the duct blaster. Some iteration between blower door and duct blaster fan speed adjustments may be needed. Record the supply pressure actually achieved and the outside duct leakage. Also measure the pressure in the return duct WRT the outside under this set-up.

- Pressurize the return ducts to $25 \mathrm{~Pa}$ WRT the outside using the duct blaster. Some iteration between blower door and duct blaster fan speed adjustments may be needed. Record the return pressure actually achieved and the outside duct leakage. Also measure the pressure in the supply duct WRT the outside under this set-up.

\section{NOTES:}

- The duct leakage to outside measurements should be equal to or less than their respective total duct leakage measurements. A common error is to depressurize the house rather than pressurize the house.

- The guidelines provided above for use of the digital gauge assumes the duct pressures are measured WRT the outside and, hence, a green hose with one end outside or in a wellventilated attic is connected to the "reference" port of channel "A." As an alternative, the duct pressures can be measured WRT the house. This is convenient when the duct blaster is being set up inside the house, usually on a return register, and the digital gauge is being used inside the house. In this case, all connections are the same except that the "reference" port for channel " $\mathrm{A}$ " is left open to the house. For the total duct leakage measurements, the supply and return ducts are again pressurized to $25 \mathrm{~Pa}$ since the house pressure is the same as the outside (the blower door fan cover was taken off in setting up this test, so the house is open to the outside). For the outside duct leakage measurements, the supply and return ducts are brought to a pressure of $0 \mathrm{~Pa}$ WRT the house, not $25 \mathrm{~Pa}$. This is because the house is pressurized to $25 \mathrm{~Pa}$ WRT the outside, so ducts that are pressurized $0 \mathrm{~Pa}$ WRT the house are also pressurized to $25 \mathrm{~Pa}$ WRT the outside. 
PRE Measurements

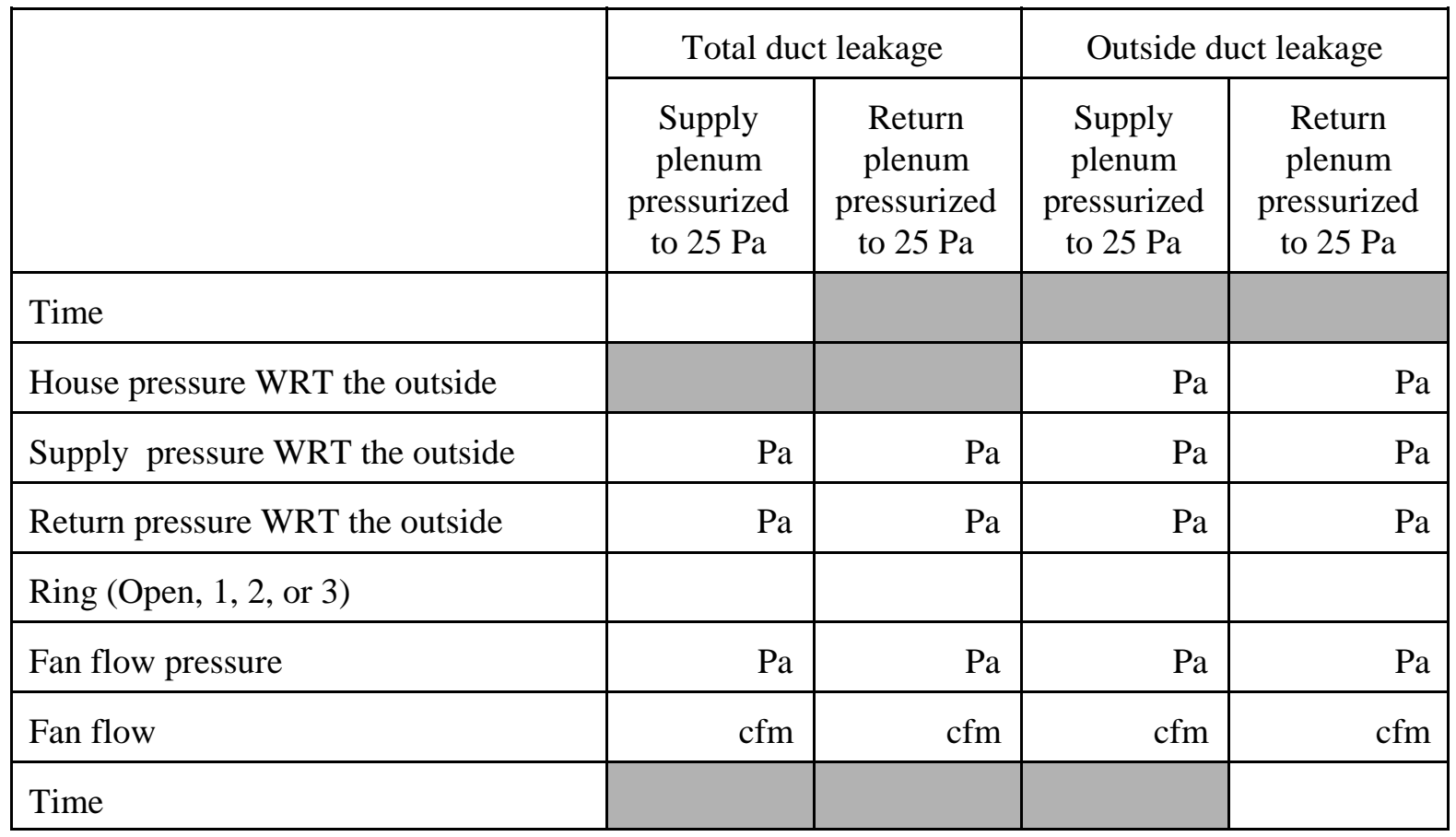

POST Measurements

\begin{tabular}{|c|c|c|c|c|}
\hline & \multicolumn{2}{|c|}{ Total duct leakage } & \multicolumn{2}{|c|}{ Outside duct leakage } \\
\hline & $\begin{array}{l}\text { Supply } \\
\text { plenum } \\
\text { pressurized } \\
\text { to } 25 \mathrm{~Pa}\end{array}$ & $\begin{array}{l}\text { Return } \\
\text { plenum } \\
\text { pressurized } \\
\text { to } 25 \mathrm{~Pa}\end{array}$ & $\begin{array}{l}\text { Supply } \\
\text { plenum } \\
\text { pressurized } \\
\text { to } 25 \mathrm{~Pa}\end{array}$ & $\begin{array}{l}\text { Return } \\
\text { plenum } \\
\text { pressurized } \\
\text { to } 25 \mathrm{~Pa}\end{array}$ \\
\hline \multicolumn{5}{|l|}{ Time } \\
\hline House pressure WRT the outside & & & $\mathrm{Pa}$ & $\mathrm{Pa}$ \\
\hline Supply pressure WRT the outside & $\mathrm{Pa}$ & $\mathrm{Pa}$ & $\mathrm{Pa}$ & $\mathrm{Pa}$ \\
\hline Return pressure WRT the outside & $\mathrm{Pa}$ & $\mathrm{Pa}$ & $\mathrm{Pa}$ & $\mathrm{Pa}$ \\
\hline \multicolumn{5}{|l|}{ Ring (Open, 1, 2, or 3) } \\
\hline Fan flow pressure & $\mathrm{Pa}$ & $\mathrm{Pa}$ & $\mathrm{Pa}$ & $\mathrm{Pa}$ \\
\hline Fan flow & $\mathrm{cfm}$ & $\mathrm{cfm}$ & $\mathrm{cfm}$ & $\mathrm{cfm}$ \\
\hline Time & & & & \\
\hline
\end{tabular}




\section{REPAIR INFORMATION}

Start time:

End time:

Estimated person-hours to perform manual repairs:

(Consider recorded start and stop times, number of people working during this time period, lunch breaks, and time spent doing tasks other than performing repairs such as collecting house information or taking photos. Typically, these person-hours should be close to the end time minus the start time times the number of people working on the house.)

Estimated material costs: $\$$

Describe the type and extent of major repairs made on this house. Identify if disconnected ducts were found and how many. Identify if sheet goods such as plywood, sheet metal, etc. were used to seal over large holes. List any unusual materials used to make repairs other than standard sealant materials such as mastic, foam, and caulk. Describe any ducts that you could not get to that you thought had major leaks in them. 
HOUSE INFORMATION

\begin{tabular}{|l|r|}
\hline Number of stories above grade & (basement, crawl space, slab) \\
\hline Types of foundation & square feet \\
\hline House area (excluding basement) & cubic feet \\
\hline House volume (excluding basement) & years \\
\hline Estimated age of house & (basement, inside house, other) \\
\hline Furnace location & \\
\hline
\end{tabular}

\section{BASEMENT INFORMATION (if present)}

\begin{tabular}{|l|r|}
\hline Basement area & square feet \\
\hline Basement volume & cubic feet \\
\hline Status & (fully finished, partially finished, unfinished) \\
\hline Presence of duct registers & (supply, return, both, none) \\
\hline Floor insulation & (installed, none) \\
\hline Banjoist insulation & (installed, none) \\
\hline Wall insulation & (installed, none) \\
\hline
\end{tabular}

\section{DUCT INFORMATION}

\begin{tabular}{|c|c|c|c|c|c|}
\hline Duct location & Supply & Return & Duct type & Supply & Return \\
\hline Attic & & & Duct board & & \\
\hline Basement & & & Flex duct & & \\
\hline Crawl space & & & Panned joist & & \\
\hline Exterior wall & & & Sheet metal & & \\
\hline Garage & & & Total & $100 \%$ & $100 \%$ \\
\hline \multicolumn{3}{|l|}{ Inside house } & & & \\
\hline \multicolumn{3}{|l|}{ Other } & & & \\
\hline Total & $100 \%$ & $100 \%$ & & & \\
\hline
\end{tabular}

\section{PHOTOS}
$\square$ House
$\square$ Air handler
$\square$ Supply duct
$\square$ Typical supply register
Duct blaster or Aeroseal set-up 



\section{FIELD TEST DATA COLLECTION FORM: AEROSEAL-TREATED HOMES}

Revised: December 30, 1999

Date:

Arrival time:

House code:

House address:

(or occupant name)

\section{HOUSE AIR LEAKAGE MEASUREMENTS}

Install the blower door and set up the house to make a blower-door measurement:

$\square$ open interior doors

$\square$ close exterior doors, windows, and doors to semi-conditioned areas

$\square$ close or seal pet doors

$\square$ close attic accesses

$\square$ close fireplace dampers

$\square$ turn off the space-heating system, water heater (to pilot), and exhaust fans (bathroom, kitchen, etc.)

$\square$ turn off powered attic fans

Depressurize the house to $50 \mathrm{~Pa}$ (house pressure WRT outside is $-50 \mathrm{~Pa}$ ) and measure the house air leakage. Make two measurements in houses with basements:

- the first measurement with the basement door to the house open and all basement windows, basement doors to the outside, etc. closed

- the second measurement with the basement door to the house closed (basement windows still closed)

\begin{tabular}{|c|c|c|c|c|}
\hline & \multicolumn{2}{|c|}{ PRE } & \multicolumn{2}{|c|}{ POST } \\
\hline & Test 1 & Test $2^{\mathrm{a}}$ & Test 1 & Test $2^{\mathrm{a}}$ \\
\hline \multicolumn{5}{|l|}{ Time } \\
\hline $\begin{array}{l}\text { House pressure } \\
\text { WRT outside }\end{array}$ & $\mathrm{Pa}$ & $\mathrm{Pa}$ & $\mathrm{Pa}$ & $\mathrm{Pa}$ \\
\hline \multicolumn{5}{|l|}{ Ring $^{\mathrm{b}}$} \\
\hline $\begin{array}{l}\text { Fan pressure } \\
\text { WRT house }\end{array}$ & $\mathrm{Pa}$ & $\mathrm{Pa}$ & $\mathrm{Pa}$ & $\mathrm{Pa}$ \\
\hline Flow rate & $\mathrm{cfm}$ & $\mathrm{cfm}$ & $\mathrm{cfm}$ & $\mathrm{cfm}$ \\
\hline Time & & & & \\
\hline
\end{tabular}

Notes: ${ }^{a}$ Use this second column only in houses with a basement to record measurements with the basement door closed.

${ }^{\mathrm{b}} \underline{\mathrm{O}}$ - Open, $\underline{\mathrm{A}}$ - Ring A, $\underline{\mathrm{B}}$ - Ring B, $\underline{\mathrm{C}}$ - Ring C 


\section{PRESSURE PAN MEASUREMENTS}

Set-up the house to make pressure pan readings:

$\square$ remove the filter from the duct system

$\square$ make sure all duct registers, grills, and dampers are fully open

$\square$ temporarily seal outside combustion air inlets or ventilation system connections which are hard ducted into the duct system

$\square$ seal supply registers in semi-conditioned spaces such as garages, etc.

$\square$ in basement houses, close the basement door to the house, open a window in the basement, and seal all basement supply and return registers

$\square$ in crawl space houses, open crawl space vents

Use the blower door to depressurize the house to $50 \mathrm{~Pa}$ (house pressure WRT outside is $-50 \mathrm{~Pa}$ ) and record the actual value achieved in the table below.

\begin{tabular}{|l|r|r|}
\hline & PRE & POST \\
\hline House pressure WRT the outside & $\mathrm{Pa}$ & $\mathrm{Pa}$ \\
\hline
\end{tabular}

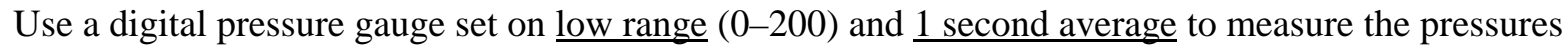
of zones with ducts located in them WRT the house. The hose measuring the zone pressure should typically be on the "input" port of the pressure gauge, and the "reference" port should be open to the house.

\begin{tabular}{|l|r|r|}
\hline \multirow{2}{*}{ Zones with ducts } & \multicolumn{2}{|c|}{ Zonal pressure WRT the house } \\
\cline { 2 - 4 } & PRE & POST \\
\hline Time & & $\mathrm{Pa}$ \\
\hline Attic & $\mathrm{Pa}$ & $\mathrm{Pa}$ \\
\hline Basement & $\mathrm{Pa}$ & $\mathrm{Pa}$ \\
\hline Crawl space & $\mathrm{Pa}$ & $\mathrm{Pa}$ \\
\hline Garage & $\mathrm{Pa}$ & $\mathrm{Pa}$ \\
\hline Other: & $\mathrm{Pa}$ & $\mathrm{Pa}$ \\
\hline Other: & & \\
\hline Time & & \\
\hline
\end{tabular}


Measure the pressure pan readings for all supply and return registers in the house, starting at the front door and working clockwise through the house. Use a digital pressure gauge set on low range (0-200) and 1 second average. The hose measuring the zone pressure should typically be on the "input" port of the pressure gauge, and the "reference" port should be open to the house.

\begin{tabular}{|c|c|c|c|c|}
\hline \multirow{2}{*}{$\begin{array}{l}\text { Register } \\
\text { number }\end{array}$} & \multirow[b]{2}{*}{ Supply or return } & \multirow[b]{2}{*}{ Zone } & \multicolumn{2}{|c|}{ Pressure WRT the house } \\
\hline & & & PRE & POST \\
\hline Time & & & & \\
\hline 1 & & & $\mathrm{~Pa}$ & $\mathrm{~Pa}$ \\
\hline 2 & & & $\mathrm{~Pa}$ & $\mathrm{~Pa}$ \\
\hline 3 & & & $\mathrm{~Pa}$ & $\mathrm{~Pa}$ \\
\hline 4 & & & $\mathrm{~Pa}$ & $\mathrm{~Pa}$ \\
\hline 5 & & & $\mathrm{~Pa}$ & $\mathrm{~Pa}$ \\
\hline 6 & & & $\mathrm{~Pa}$ & $\mathrm{~Pa}$ \\
\hline 7 & & & $\mathrm{~Pa}$ & $\mathrm{~Pa}$ \\
\hline 8 & & & $\mathrm{~Pa}$ & $\mathrm{~Pa}$ \\
\hline 9 & & & $\mathrm{~Pa}$ & $\mathrm{~Pa}$ \\
\hline 10 & & & $\mathrm{~Pa}$ & $\mathrm{~Pa}$ \\
\hline 11 & & & $\mathrm{~Pa}$ & $\mathrm{~Pa}$ \\
\hline 12 & & & $\mathrm{~Pa}$ & $\mathrm{~Pa}$ \\
\hline 13 & & & $\mathrm{~Pa}$ & $\mathrm{~Pa}$ \\
\hline 14 & & & $\mathrm{~Pa}$ & $\mathrm{~Pa}$ \\
\hline 15 & & & $\mathrm{~Pa}$ & $\mathrm{~Pa}$ \\
\hline 16 & & & $\mathrm{~Pa}$ & $\mathrm{~Pa}$ \\
\hline 17 & & & $\mathrm{~Pa}$ & $\mathrm{~Pa}$ \\
\hline 18 & & & $\mathrm{~Pa}$ & $\mathrm{~Pa}$ \\
\hline 19 & & & $\mathrm{~Pa}$ & $\mathrm{~Pa}$ \\
\hline Time & & & & \\
\hline
\end{tabular}




\section{HOUSE PRESSURE/DOMINANT DUCT LEAKAGE TESTS}

Set up the house to make house pressure/dominant duct leakage measurements: seal off the blower door fan reinstall the air filter keep supply registers in semi-conditioned spaces such as garages, etc. sealed as done for the pressure pan measurements

keep basement supply and return registers sealed as done for the pressure pan measurements in basement houses, keep the basement door to the house closed and a window in the basement opened as done for the pressure pan measurements

Use the Aeroseal software to measure the pressure of the main part of the house WRT a wellventilated attic (preferred) or crawl space (both representing outside) with

- the air handler fan off

- the air handler fan on

- the air handler fan on and the return registers blocked $80 \%$

- the air handler fan off.

To make the PRE measurements:

- Place the Aeroseal suitcase in the main part of the house.

- Start the Aeroseal program (double-click on the Aeroseal ICON).

- Select NEW customer and enter the customer information for this house into the program (occupant name, address, etc.). If possible, enter the field test house code as well.

- Step through the screens until you reach the DUCT LEAKAGE ANALYSIS page with the gauge on it. Use the "TAB" key in stepping through these pages and insert the numeral "1" for all entries except the "Last Service Date" on the AC UNIT page, which should be entered as $11 / 11$.

- Follow the directions on the DUCT LEAKAGE ANALYSIS page to set the equipment up for the test. For example, connect the blue hose measuring the attic pressure to the blue nipple on the suitcase.

- Run through the four DUCT LEAKAGE ANALYSIS measurements. The measured data are automatically stored for you on the computer (you do not need to manually record any values).

- The first and last measurements with the air handler fan off should be nearly the same since they are taken with the house set up under identical conditions. The third measurement, with the return registers blocked, should always be greater than the second measurement (e.g., 4 Pa compared with $2 \mathrm{~Pa},-1 \mathrm{~Pa}$ compared with $-3 \mathrm{~Pa}, 1 \mathrm{~Pa}$ compared with $-3 \mathrm{~Pa}$ ). The Aeroseal software automatically checks to see if the measured values are reasonable and, if not, the software will indicate that a retest is needed. 
To make the POST measurements:

- Place the Aeroseal suitcase in the main part of the house. The software should already be running from previous tests.

- Go to the ORNL TEST customer in the software - click on RETURN TO WELCOME, click on EXISTING, and select ORNL TEST customer. Use VIEW to skip directly to the HOUSE-PRESSURE test. (NOTE: The ORNL TEST customer may need to be created the first time you ever run the program. After it has been created, you can use the procedure above to skip directly to the HOUSE-PRESSURE test.)

- Follow the directions on the DUCT LEAKAGE ANALYSIS page to set the equipment up for the test. For example, connect the blue hose measuring the attic pressure to the blue nipple on the suitcase.

- $\quad$ Run through the four DUCT LEAKAGE ANALYSIS measurements. After each test, record the measured value in the table below.

- The first and last measurements with the air handler fan off should be nearly the same since they are taken with the house set up under identical conditions. The third measurement, with the return registers blocked, should always be greater than the second measurement (e.g., 4 $\mathrm{Pa}$ compared with $2 \mathrm{~Pa},-1 \mathrm{~Pa}$ compared with $-3 \mathrm{~Pa}, 1 \mathrm{~Pa}$ compared with $-3 \mathrm{~Pa}$ ). The Aeroseal software automatically checks to see if the measured values are reasonable and, if not, the software will indicate that a retest is needed.

\begin{tabular}{|l|r|r|r|r|}
\hline & $\begin{array}{c}\text { Air handler } \\
\text { fan off }\end{array}$ & $\begin{array}{c}\text { Air handler } \\
\text { fan on }\end{array}$ & $\begin{array}{c}\text { Air handler fan on } \\
\text { and return registers } \\
\text { blocked 80\% }\end{array}$ & $\begin{array}{c}\text { Air handler } \\
\text { fan off }\end{array}$ \\
\hline $\begin{array}{l}\text { House pressure WRT the } \\
\text { attic (outside) }\end{array}$ & $\mathrm{Pa}$ & $\mathrm{Pa}$ & $\mathrm{Pa}$ & $\mathrm{Pa}$ \\
\hline
\end{tabular}




\section{COMBUSTION SAFETY TESTS}

Set up the house to make combustion safety tests:

unblock the return registers

in basement houses, close the basement windows

unseal any registers in the basement or in semi-conditioned spaces such as garages that may have been sealed to make pressure pan and dominant duct leakage measurements

In each combustion zone:

- Use procedures and approaches established by your agency to set up the house in a "worst case" scenario to test for combustion safety. Record the combustion appliances in the combustion zone as well as information on operation of the air handler fan, interior and basement door closures, and operation of exhaust fans to produce this worst case.

- Measure the pressure in the combustion zone WRT a well-ventilated attic (preferred) or crawl space (both representing outside) using a digital gauge set on low range (0-200) and 5 second average. The hose (usually green) measuring the attic pressure should typically be on the "reference" port of the pressure gauge, and the "input" port should be open to the combustion zone.

- Measure the draft of the combustion appliance and visually observe if spillage is occurring (if these are part of your normal inspection procedures).

- Based on your interpretation of these measurements and other measurements you have made, determine if there is a safety problem in this combustion zone.

- If a safety problem is indicated in the combustion zone after making the post safety inspections, perform any additional repairs necessary to mitigate the safety concern. Record the work performed and collect a final set of measurements. 


\section{Combustion Zone 1}

Combustion Appliances Present: $\square$ Space-heating system

$\square$ Water-heating system

$\square$ Fireplace

$\square$ Gas dryer

$\square$ Other:

Worst Case Conditions:

\begin{tabular}{|l|l|l|l|}
\hline & PRE & POST & FINAL \\
\hline Time & & & \\
\hline Air handler fan (on, off) & & & \\
\hline Number of interior doors closed & & & \\
\hline Basement door (open, closed, NA) & & & \\
\hline Number of bathroom fans on & & & \\
\hline Kitchen range hood fan (on, off, NA) & & & \\
\hline Dryer (on, off, NA) & & & \\
\hline Other exhaust fan (on, off, NA): & & & \\
\hline
\end{tabular}

Combustion safety measurements:

\begin{tabular}{|l|r|r|r|}
\hline & PRE & POST & FINAL \\
\hline Combustion zone pressure WRT the attic (outside) & $\mathrm{Pa}$ & $\mathrm{Pa}$ & $\mathrm{Pa}$ \\
\hline Draft & in. w.c. & in.w.c. & in. w.c. \\
\hline Visual spillage (yes, no, NA) & & & \\
\hline Time & & & \\
\hline
\end{tabular}

Is there a combustion safety problem in this zone?
PRE: $\square$ Yes
POST: $\square$ Yes
FINAL: $\square$ Yes
$\square$ No
$\square$ No
$\square$ No

Repairs performed to mitigate safety problems found in this combustion zone following post inspections were: 


\section{Combustion Zone 2}

Combustion Appliances Present: $\quad \square$ Space-heating system

$\square$ Water-heating system

$\square$ Fireplace

$\square$ Gas dryer

$\square$ Other:

Worst Case Conditions:

\begin{tabular}{|l|l|l|l|}
\hline & PRE & POST & FINAL \\
\hline Time & & & \\
\hline Air handler fan (on, off) & & & \\
\hline Number of interior doors closed & & & \\
\hline Basement door (open, closed, NA) & & & \\
\hline Number of bathroom fans on & & & \\
\hline Kitchen range hood fan (on, off, NA) & & & \\
\hline Dryer (on, off, NA) & & & \\
\hline Other exhaust fan (on, off, NA): & & & \\
\hline
\end{tabular}

Combustion safety measurements:

\begin{tabular}{|l|r|r|r|}
\hline & PRE & POST & FINAL \\
\hline Combustion zone pressure WRT the attic (outside) & $\mathrm{Pa}$ & $\mathrm{Pa}$ & $\mathrm{Pa}$ \\
\hline Draft & in. w.c. & in. w.c. & in. w.c. \\
\hline Visual spillage (yes, no, NA) & & & \\
\hline Time & & & \\
\hline
\end{tabular}

Is there a combustion safety problem in this zone?
PRE: $\square$ Yes
POST: $\square$ Yes
FINAL: $\square$ Yes
$\square$ No
$\square$ No
$\square$ No

Repairs performed to mitigate safety problems found in this combustion zone following post inspections were: 


\section{DUCT OPERATING PRESSURE MEASUREMENTS}

Drill a small hole in the supply plenum near the air handler fan and two small holes in the return plenum - one upstream and one downstream of the air filter.

Measure the pressures in the supply and return plenums WRT the room or the part of the house where the plenums are located with the air handler fan operating. Use a digital gauge set on low range $(0-200)$ and 1 second average.

\begin{tabular}{|l|r|r|}
\hline & PRE & POST \\
\hline Time & & Pa \\
\hline Supply plenum pressure WRT the house & $\mathrm{Pa}$ & $\mathrm{Pa}$ \\
\hline $\begin{array}{l}\text { Return plenum pressure upstream of the } \\
\text { air filter WRT the house }\end{array}$ & $\mathrm{Pa}$ & $\mathrm{Pa}$ \\
\hline $\begin{array}{l}\text { Return plenum pressure downstream of the } \\
\text { air filter WRT the house }\end{array}$ & & \\
\hline Time & & \\
\hline
\end{tabular}




\section{DUCT LEAKAGE MEASUREMENTS}

Install the Aeroseal machine to the supply side of the air handler via the flange or use two registers with the "Y" connector if need be.

Connect the Aeroseal suitcase to the Aeroseal machine. Locate the Aeroseal suitcase in the same zone as the ducts and the sealing machine, or use tubing to connect the nipple opposite the red nipple on the suitcase to the zone where the Aeroseal machine is located and the nipple opposite the blue nipple to the zone where the ducts are located.

Set up the house for the duct leakage measurements:

remove the air filter

seal off all supply and return registers with masking tape or ductmask

$\square$ unseal the blower door fan so that outside air can enter the house through the fan opening

$\square$ in basement houses, close the basement door to the house and open a basement window

Go to the ORNL TEST customer in the Aeroseal software (the software should already be running from the house pressure test) - click on RETURN TO WELCOME, click on EXISTING, and select ORNL TEST customer. Use VIEW to skip directly to the PRE-SEAL test.

Make two measurements of the total duct leakage using the Aeroseal equipment while on the ORNL TEST customer, and write the results in the tables that follow:

- Pressurize the supply ducts to 25 Pa WRT the outside using the PRE-SEAL test. (NOTE: If you accidently ever go on the sealing process for the ORNL TEST customer, you will not be able to use the PRE-TEST. In this case, you will have to use the POST-SEAL test or enter another DUMMY customer).

- Pressurize the return ducts to 25 Pa WRT the outside using the PRE-SEAL test. (i.e. the same as the previous test, except using the pressure in the return plenum instead of the supply plenum)

Pressurize the house to $25 \mathrm{~Pa}$ using the blower door. Make two measurements of the duct leakage to outside using the Aeroseal equipment while on the ORNL Test customer, and write the results in the tables that follow:

- Pressurize the supply ducts to 25 Pa WRT the outside using the PRE-SEAL test.

- Pressurize the return ducts to 25 Pa WRT the outside using the PRE-SEAL test. (i.e. the same as the previous test, except using the pressure in the return plenum instead of the supply plenum) 
NOTES: - The duct leakage to outside measurements should be equal to or less than their respective total duct leakage measurements. A common error is to depressurize the house rather than pressurize the house.

PRE Measurements

\begin{tabular}{|c|c|c|c|c|}
\hline & \multicolumn{2}{|c|}{ Total duct leakage } & \multicolumn{2}{|c|}{ Outside duct leakage } \\
\hline & $\begin{array}{l}\text { Supply } \\
\text { plenum } \\
\text { pressurized } \\
\text { to } 25 \mathrm{~Pa}\end{array}$ & $\begin{array}{l}\text { Return } \\
\text { plenum } \\
\text { pressurized } \\
\text { to } 25 \mathrm{~Pa}\end{array}$ & $\begin{array}{l}\text { Supply } \\
\text { plenum } \\
\text { pressurized } \\
\text { to } 25 \mathrm{~Pa}\end{array}$ & $\begin{array}{l}\text { Return } \\
\text { plenum } \\
\text { pressurized } \\
\text { to } 25 \mathrm{~Pa}\end{array}$ \\
\hline \multicolumn{5}{|l|}{ Time } \\
\hline House pressure WRT the outside & & & $\mathrm{Pa}$ & $\mathrm{Pa}$ \\
\hline Supply pressure WRT the outside & $25 \mathrm{~Pa}$ & & $25 \mathrm{~Pa}$ & \\
\hline Return pressure WRT the outside & & $25 \mathrm{~Pa}$ & & $25 \mathrm{~Pa}$ \\
\hline \multicolumn{5}{|l|}{ Gate $(1,2,3$, or 4$)$} \\
\hline Fan flow & $\mathrm{cfm}$ & $\mathrm{cfm}$ & $\mathrm{cfm}$ & $\mathrm{cfm}$ \\
\hline Time & & & & \\
\hline
\end{tabular}

POST Measurements

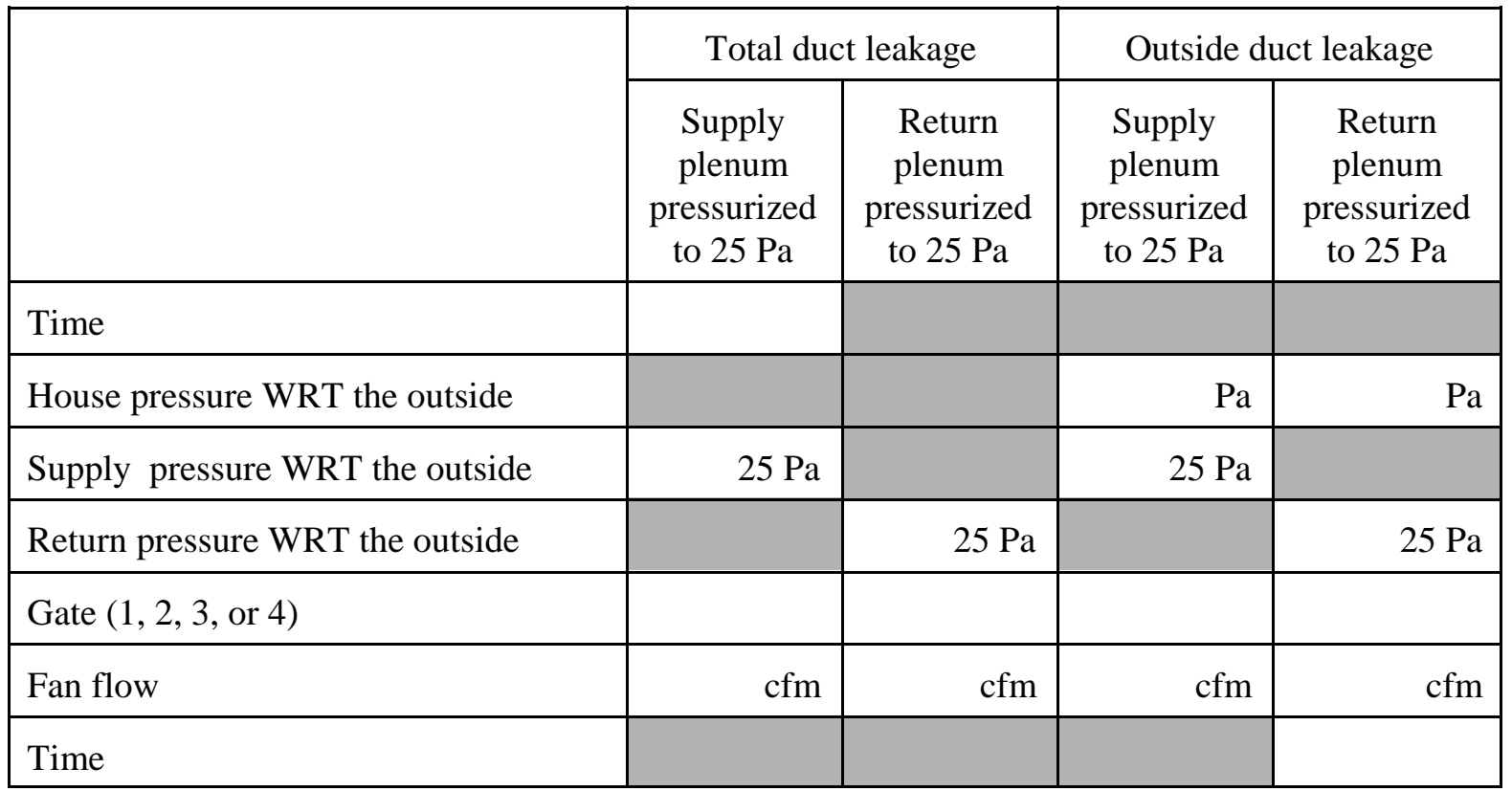




\section{SEALING DUCTS WITH THE AEROSEAL MACHINE}

- Turn off the blower door.

- Go to the CUSTOMER BEING TESTED/SEALED customer in the Aeroseal software (the software should already be running from the duct leakage test) - click on RETURN TO WELCOME, click on EXISTING, and select CUSTOMER BEING TESTED/SEALED customer.

- Select SEAL IT! and step through to the PRE-SEAL test. With the blue tube in the supply duct and the blower door off, make one measurement of the total duct leakage.

- BLOCK THE HEAT EXCHANGER AND BLOCK THE REGISTERS WITH FOAM BEFORE INJECTING AEROSOL.

- Begin the injection process. PRESSURIZE THE HOUSE (5-10 PA) WITH THE BLOWER DOOR DURING INJECTION.

- When the sealing is completed, remove the heat exchanger block and turn off the blower door fan before performing the POST-SEAL test with the blue tube in supply duct. 


\section{REPAIR INFORMATION}

Start time:

End time:

Estimated person-hours to perform manual repairs:

(Consider recorded start and stop times, number of people working during this time period, lunch breaks, and time spent doing tasks other than performing repairs such as collecting house information or taking photos. Typically in the aerosol-treated houses, these person-hours should be much less than the end time minus the start time times the number of people working on the house since manual sealing is performed only for a part of the time the aerosol machine is working.)

Estimated material costs: \$ (Do not include the cost of the aerosol spray.)

Describe the type and extent of major repairs made on this house, especially those made manually. Identify if disconnected ducts were found and how many. Identify if sheet goods such as plywood, sheet metal, etc. were used to seal over large holes. List any unusual materials used to make repairs other than standard sealant materials such as mastic, foam, and caulk. Describe any ducts that you could not get to that you thought had major leaks in them. 
HOUSE INFORMATION

\begin{tabular}{|l|r|}
\hline Number of stories above grade & (basement, crawl space, slab) \\
\hline Types of foundation & square feet \\
\hline House area (excluding basement) & cubic feet \\
\hline House volume (excluding basement) & years \\
\hline Estimated age of house & (basement, inside house, other) \\
\hline Furnace location & \\
\hline
\end{tabular}

\section{BASEMENT INFORMATION (if present)}

\begin{tabular}{|l|r|}
\hline Basement area & square feet \\
\hline Basement volume & cubic feet \\
\hline Status & (fully finished, partially finished, unfinished) \\
\hline Presence of duct registers & (supply, return, both, none) \\
\hline Floor insulation & (installed, none) \\
\hline Banjoist insulation & (installed, none) \\
\hline Wall insulation & (installed, none) \\
\hline
\end{tabular}

\section{DUCT INFORMATION}

\begin{tabular}{|c|c|c|c|c|c|}
\hline Duct location & Supply & Return & Duct type & Supply & Return \\
\hline Attic & & & Duct board & & \\
\hline Basement & & & Flex duct & & \\
\hline Crawl space & & & Panned joist & & \\
\hline Exterior wall & & & Sheet metal & & \\
\hline Garage & & & Total & $100 \%$ & $100 \%$ \\
\hline \multicolumn{3}{|l|}{ Inside house } & & & \\
\hline \multicolumn{3}{|l|}{ Other } & & & \\
\hline Total & $100 \%$ & $100 \%$ & & & \\
\hline
\end{tabular}

\section{PHOTOS}

$\square$ House

$\square$ Air handler $\square$ Supply duct

$\square$ Return duct $\square$ Typical supply register

$\square$ Typical return register
Duct blaster or Aeroseal set-up 


\section{APPENDIX B}

\section{WEATHERIZATION AGENCY QUESTIONNAIRE}

The following questionnaire was provided to each of the five participating weatherization agencies to gain their feedback on the aerosol-spray and conventional, best-practice duct sealing technologies as implemented under this field test. 



\section{DUCT LEAKAGE FIELD TEST QUESTIONNAIRE}

\section{AEROSOL TECHNOLOGY}

1. Was the training you received on the aerosol technology sufficient to implement the technology in the field test? Please comment on both the software (running the program, collecting the field data using the aerosol software, and data transfer) and hardware aspects of the technology. Please address training areas that were emphasized too much or too little, adequacy of the classroom training, and adequacy of the field portion of the training.

2. What problems did you encounter in using the aerosol technology during the field test? Please comment on both software and hardware issues. Please address data collection, set-up (including connection to the ducts), sealing, and data downloading.

3. How could the aerosol technology be improved to make it easier to use or to obtain better duct leakage reductions? Consider both software and hardware changes.

4. Based on your experience, what are the advantages and disadvantages in using the aerosol technology versus just current duct-sealing techniques? Please address diagnostics, duct leakage reductions, documentation and recording, labor time, materials, costs, ease of sealing, and customer satisfaction.

5. The aerosol technology has a software package that steps a person through duct diagnostics and automatically documents audit data and results. We used only one piece of the software in the field test - measuring the dominant duct leakage in the aerosol houses. Would this type of software be useful in your day-to-day activities if it were tailored more to the diagnostic approaches you perform for ducts or the house?

6. Forgetting about equipment costs, do you think the aerosol technology would be a useful tool for YOUR agency? Please explain why or why not.

7. Based on your experience, would you recommend that the aerosol technology be adopted within the Weatherization Assistance Program with your state or region, or at the national level? Please address which aspects of the aerosol technology fit well within the weatherization program, and which aspects limit its implementation. Please consider cost of the equipment, skill level required to implement the technology, integration into current agency programs, potential for time and cost savings and better duct leakage reductions, training needs, and impact on auditing and work write-up approaches.

8. How would you recommend an agency and/or state implement the aerosol technology into their Weatherization Assistance Program? Please comment on whether the technology is best implemented by a separate, specialized crew or by the regular weatherization crews, and how auditing and work write-ups might be impacted.. If a regular weatherization crew were to implement the aerosol technology, please identify what other work could be performed during duct sealing and what work could not be performed during duct sealing.

9. How much training would be required by Weatherization Assistance Program agencies to implement the aerosol technology? Please address the number and lengths of training sessions needed by a crew to become competent in the new technology, the mix of classroom and field training needed, and the forum for these trainings. 


\section{CONVENTIONAL DUCT SEALING TECHNOLOGY}

1. As part of the field test, duct leakage measurements were made before and after duct sealing to document the reductions achieved. These measurements were made with the Minneapolis duct blaster in the conventional houses and with the aerosol equipment in the aerosol houses. Such measurements are not routinely made by weatherization agencies in performing duct sealing. Based on your experience:

A.. Do you think these measurements provide useful information to assist in production-mode duct sealing. Please consider if the measurements help diagnose if ducts need sealing, where leaks are, and if ducts have been sufficiently sealed. Please address how this information supplements information already collected, such as pressure-pan measurements.

B. Would you recommend that these measurements be incorporated into a weatherization program agency's duct sealing program? Please consider equipment costs, labor and time to make the measurements, and useful information obtained.

C. How much training is required to get agency personnel competent in this technology?

2. As part of the field test, dominant duct leakage measurements were made before and after duct sealing. Such measurements are not routinely made by weatherization agencies in performing duct sealing. Based on your experience:

A.. Do you think these measurements provide useful information to assist in production-mode duct sealing. Please consider if the measurements help diagnose if ducts need sealing, where leaks are, and if ducts have been sufficiently sealed. Please address how this information supplements information already collected, such as pressure-pan measurements.

B. Would you recommend that these measurements be incorporated into a weatherization program agency's duct sealing program? Please consider equipment costs, labor and time to make the measurements, and useful information obtained.

C. How much training is required to get agency personnel competent in this technology?

3. As part of the field test, zonal measurements were made before and after duct sealing to supplement the pressure-pan measurements. Such measurements are not routinely made by weatherization agencies in performing duct sealing. Based on your experience: 
A. Do you think these measurements provide useful information to assist in production-mode duct sealing. Please consider if the measurements help diagnose if ducts need sealing, where leaks are, and if ducts have been sufficiently sealed. Please address how this information supplements information already collected, such as pressure-pan measurements.

B. Would you recommend that these measurements be incorporated into a weatherization program agency's duct sealing program? Please consider equipment costs, labor and time to make the measurements, and useful information obtained.

C. How much training is required to get agency personnel competent in this technology? 

ORNL/CON-480

\section{DISTRIBUTION}

1. V. D. Baxter

2. L. G. Berry

3. M. A. Brown

4. P. W. Childs

5. J. E. Christian

6. W. G. Craddick

7. A. O. Desjarlais

8-37. M. T. Eady

38. E. C. Fox

39. M. B. Gettings
40. H. L. Hwang

41-42. B. J. Kirby

43. P. M. Love

44. C. I. Moser

45. J. R. Sand

46. T. K. Stovall

47-93. M. P. Ternes

94. R. L. Wendt

95. Central Research Library

96. ORNL Laboratory Records-RC

\section{EXTERNAL DISTRIBUTION}

97. Chris Baker, Wyoming Energy Council, P.O. Box 972, Laramie, WY 82073

98. Bill Beachy, Virginia Mountain Housing, 930 Cambria Street, Christiansburg, VA 24073

99. Dana Bres, U.S. Department of Housing and Urban Development, 451 7th Street, S.W., Room 8134, Washington, DC 20410

100. Elizabeth Cahall, U.S. Department of Energy, Philadelphia Regional Office (PRO), 1880 John F. Kennedy Boulevard, Suite 501, Philadelphia, PA 19103-7483

101. Chris Clay, The Opportunity Council, 314 East Holly Street, Bellingham, WA 98225

102. Anthony Cox, Virginia Mountain Housing, 930 Cambria Street, Christiansburg, VA 24073

103. John Davies, The Opportunity Council, 1701 Ellis Street, Bellingham, WA 98225

104. Robert Desoto, U.S. Department of Energy, Denver Regional Office (DRO), 1617 Cole Boulevard, MS-1721, Golden, CO 80401

105-109. Jean Diggs, U.S. Department of Energy, Office of Building Technology Assistance (EE-42), Room 5E-080, 1000 Independence Avenue, S.W., Washington, DC 20585

110. Robert Doherty, Wyoming Energy Council, P.O. Box 972, Laramie, WY 82073

111. Chris Early, U.S. Department of Energy, Office of Building Research and Standards (EE-41), Room 1J-018, 1000 Independence Avenue, S.W., Washington, DC 20585

112-116. Joel Eisenberg, Oak Ridge National Laboratory, 901 D Street, S.W., Suite 910, Washington, DC 20024

117. David Engel, U.S. Department of Housing and Urban Development, 451 7th Street, S.W., Room 8134, Washington, DC 20410

118-122. Denis Feck, U.S. Department of Energy, Office of Building Technology Assistance (EE-42), Room 5E-098, 1000 Independence Avenue, S.W., Washington, DC 20585

123. Dave Finet, The Opportunity Council, 314 East Holly Street, Bellingham, WA 98225

124. Carole Gates, U.S. Department of Energy, Seattle Regional Office (SRO), 800 Fifth Avenue, Suite 3950, Seattle, WA 98104

125. Ed Gerardot, Indiana Community Action Association, 1845 West 18th Street, Indianapolis, IN 46202-1015

126. Mark Ginsberg, U.S. Department of Energy, Office of Building Technology, State and Community Programs (EE-40), Room 5E-052, 1000 Independence Avenue, S.W., Washington, DC 20585 
127-131. Bob Groberg, U.S. Department of Housing and Urban Development, 451 7th Street, S.W., Room 7250, Washington, DC 20410

132. Esher Kweller, U.S. Department of Energy, Office of Building Research and Standards (EE-41), Room 1J-018, 1000 Independence Avenue, S.W., Washington, DC 20585

133. Tim Lenaham, Ohio Office of Energy Efficiency, Department of Development, 77 South High Street, Columbus, OH 43215-1001

134. Karen Linner, Builders Association of Minnesota, 570 Asbury Street, Suite 301, St. Paul, MN 55104

135. Terry Logee, U.S. Department of Energy, Office of Building Research and Standards (EE-41), Room 1J-018, 1000 Independence Avenue, S.W., Washington, DC 20585

136. Mike Loos, Iowa East Central TRAIN, 2804 Eastern Avenue, Davenport, IA 52803

137. Emiliano Lopez, Wyoming Energy Council, P.O. Box 972, Laramie, WY 82073

138. David Mark, U.S. Department of Energy, Boston Regional Office (BRO), John F. Kennedy Federal Building, Room 675, Boston, MA 02203-0002

139. Gail McKinley, U.S. Department of Energy, Office of Building Technology Assistance (EE-42), Room 5E-080, 1000 Independence Avenue, S.W., Washington, DC 20585

140. Mark Modera, Aeroseal, 75 Fairview Avenue, Piedmont, CA 94610

141. Alex Moore, D\&R International, 1300 Spring Street, Suite 500, Silver Spring, MD 20910

142. Celeste Moerle, U.S. Department of Energy, Chicago Regional Office (CRO), One South Wacker Drive, Chicago, IL 60606-4616

143. Michael Peterson, U.S. Department of Energy, Chicago Regional Office (CRO), MS EE-63, One South Wacker Drive, Chicago, IL 60606-4616

144. Gregory Reamy, U.S. Department of Energy, Office of Building Technology Assistance (EE-42), Room 5E-066, 1000 Independence Avenue, S.W., Washington, DC 20585

145. Bernadette Ruffin, U.S. Department of Energy, Atlanta Regional Office (ARO), 75 Spring Street, Suite 200, Atlanta, GA 30308-3308

146. Russ Shaber, Office of Energy Management, 225 East 16th Avenue, Suite 650, Denver, CO 80203

147. Jon Stone, U.S. Department of Energy, Office of Building Research and Standards (EE-41), Room IM-048, 1000 Independence Avenue, S.W., Washington, DC 20585

148. Edwin Stromberg, U.S. Department of Housing and Urban Development, 451 7th Street, S.W., Room 8134, Washington, DC 20410

149. Rich Szydlowski, Center for Energy and Environment, Suite 455, 211 North 1st Street, Minneapolis, MN 55401

150. Emory White, CASE of West Virginia, 212 Federal Street, Bluefield, WV 24701 